\title{
Biological Approaches to Therapy of Pancreatic Cancer
}

\author{
Han Hsi Wong and Nicholas R Lemoine \\ Centre for Molecular Oncology, Institute of Cancer, Barts and The London School of Medicine \\ and Dentistry, Queen Mary, University of London, London, UK
}

\begin{abstract}
Pancreatic cancer is a lethal disease and notoriously difficult to treat. Only a small proportion is curative by surgical resection, whilst standard chemotherapy for patients with advanced disease has only modest effect with substantial toxicity. Clearly there is a need for the continual development of novel therapeutic agents to improve the current situation. Improvement of our understanding of the disease has generated a large number of studies on biological approaches targeting the molecular abnormalities of pancreatic cancer, including gene therapy and signal transduction inhibition, antiangiogenic and matrix metalloproteinase inhibition, oncolytic viral therapy and immunotherapy. This article provides a review of these approaches, both investigated in the laboratories and in subsequent clinical trials.
\end{abstract}

\section{Keywords}

pancreatic cancer; treatment; therapy; gene; inhibitor; oncolytic; virus; immunotherapy

\section{Introduction}

Pancreatic cancer remains one of the most difficult conditions to treat, with only about $10 \%$ of patients presenting with resectable disease suitable for potentially curative surgery [1]. Outcome has not improved substantially over the past 25 years, with overall five-year survival remaining dismally poor at $5 \%$ [2]. Patients with locally advanced disease have a median survival of six to ten months, whilst for those with metastatic disease it is only three to six months [3].

For many years, 5-fluorouracil (5-FU) has been the standard chemotherapeutic regime for pancreatic cancer. Gemcitabine became the new standard of treatment after the publication of a phase III trial in 1997, showing a modest survival advantage over 5-FU and better alleviation of disease-related symptoms [4]. Recent meta-analyses showed that gemcitabinebased combination chemotherapy has a significant survival benefit over gemcitabine alone in locally advanced and metastatic pancreatic cancers [5]. There is currently insufficient evidence to endorse the use of chemoradiation, followed by chemotherapy, over chemotherapy alone in locally advanced disease [1]. As these conventional treatments often have limited effect and substantial toxicity, a strong need exists for novel therapies.

Biological approaches that target pancreatic cancer at a molecular level are rapidly evolving and represent promising strategies to treat this deadly disease (Table 1).

\footnotetext{
Corresponding author: Han Hsi Wong, MB ChB MRCP(UK) Centre for Molecular Oncology, Institute of Cancer, Barts and The London School of Medicine and Dentistry, Queen Mary, University of London, Charterhouse Square, London EC1M 6BQ, UK. Tel: +44 207014 0435, Fax: +44 2070140453 han-hsi.wong@ @ancer.org.uk.
} 


\section{Gene Therapy and Signal Transduction Inhibition}

The genetics and pathogenesis of pancreatic cancer is one of the most complicated of the malignant diseases [6]. Multiple genetic mutations have been identified as the precursor to the development of pancreatic cancer but none are mutually exclusive (Table 2). Gene therapy involves the introduction of exogenous nucleic acids into cells. By expressing, restoring or inhibiting a particular gene of interest, it is hoped that this would prevent or reverse the growth of cancer cells. Complex tumour-promoting signalling pathways have also been identified and these can be targeted by molecular inhibitors.

\section{Signal Transduction Pathways}

Ras-The K-ras oncogene (homologous to the ras gene of Kirsten murine sarcoma virus) mutation, mostly at codon 12 but also occasionally at codons 13 and 61, occurs in 75-90\% of pancreatic cancers [7]. The gene encodes a $21 \mathrm{kDa}$ membrane-bound guanosine triphosphate (GTP)-binding protein involved in growth factor-mediated signal transduction pathways. It can be activated through the overexpression or activation of ras-activating signalling partners, such as the epidermal growth factor receptor (EGFR). The best characterised effector pathway in ras function is the Raf/mitogen-activated protein kinase (MAPK)/extracellular signal-regulated kinase (ERK) (MEK) cascade. Mutations result in impaired GTPhosphatase (GTPase) activity, causing it to be locked in the GTP-bound state and thus activating downstream signalling cascades [8]. There is no significant difference in the prevalence of K-ras mutation at different stages of the disease [9], and they are often found in benign lesions of the pancreas [10], indicating that activation of this oncogene is involved in the initiation or early phase of carcinogenesis. Another less characterised member of the ras family, H-ras (homologous to the ras gene of Harvey murine sarcoma virus), also plays a role in promoting tumour growth. The H-ras-ERK cascade is activated by transforming growth factor-a (TGF-a) in pancreatic cancer cells with K-ras mutations [11].

Antisense gene therapy involves the administration of oligonucleotides with sequences complementary to regions of specific mRNA strands, resulting in the prevention of gene translation. Transfection with a plasmid encoding antisense K-ras RNA (AS-K-ras-LNSX) suppressed growth of several human pancreatic cancer cell lines and administration of this agent to nude mice bearing the pancreatic AsPC-1 peritoneal implants inhibited tumour progression [12]. N116Y is a dominant negative $\mathrm{H}$-ras mutant, derived from the v-H-ras oncogene by substituting asparagine with tyrosine at codon 116, which is in the GTPbinding domain $[13,14]$. N116Y prevents the activation of oncogenic ras protein with which it competes for a guanine nucleotide exchange factor [15]. An E1-deleted, replicationdeficient Ad (Ad CEA-N116Y), in which N116Y was driven by the human carcinoembryonic antigen (CEA) promoter, effectively reduced the number of PCI-43 hepatic metastases following intrasplenic injection [14]. In a phase II trial of the antisense inhibitor of H-ras ISIS-2503 in combination with gemcitabine, patients with locally advanced or metastatic pancreatic adenocarcinoma showed a response rate of $10.4 \%$ and a median survival (MS) of 6.6 months [16] (5\% and 5.7 months respectively for gemcitabine alone [4]).

RNA interference is a relatively new technology in comparison to the antisense system. The gene silencing process of RNA interference involves the manufacture of short, doublestranded RNAs ( $<30$ base pair), termed small interfering RNAs (siRNAs), by the RNase enzyme Dicer. These siRNAs are then incorporated into a silencing complex called RISC (RNA-induced silencing complex), which identifies and silences complementary mRNA [17]. siRNAs targeting K-ras reduced proliferation of Panc-1 and MIAPaCa-2 pancreatic cancer cell lines, although only MIAPaCa-2 showed increased apoptosis [18]. Retroviral 
delivery of siRNAs inhibited the growth of Capan-1 cells, both in vitro and in vivo [19]. Inhibition of the mutant K-ras ${ }^{\mathrm{v} 12}$ was shown whilst other ras isoforms were unaffected, demonstrating the extraordinary specificity of siRNA as the wild-type and mutant ras differs only in a single codon.

Post-translational modification of ras protein involves the addition of a 15-carbon farnesyl isoprenoid moiety to the cysteine residue of the $\mathrm{C}$ terminus, mediated by farnesyl protein transferase. Farnesylation is necessary for ras to attach to the cell membrane. However tipifarnib (R115777), a farnesyltransferase inhibitor (FTI), has been disappointing in a phase III study of 688 patients [20]. The MS for the gemcitabine plus tipifarnib arm was 193 compared with 182 days for gemcitabine plus placebo $(\mathrm{p}=0.75)$, with no difference in oneyear survival and progression-free survival (PFS). Possible explanations include the fact that although H-ras is exclusively modified by FT, K-ras and N-ras can also be modified by geranylgeranyltransferase (GGT) [21]. This provides an alternative route to the creation of biologically active ras. Furthermore FTI works by inducing cell cycle arrest, whereas gemcitabine requires cell cycle progression to be effective [22]. Nevertheless FTI and siRNA inhibition of FT has been found to increase the sensitivity of pancreatic cancer cell lines to radiation [22,23]. FTI and GGTI in combination enhanced tumour apoptosis in mice bearing the pancreatic tumour PSN-1 despite significant toxicity [24]. L-778,123, a dual inhibitor of FT and GT, has been tested in a phase I trial in combination with radiotherapy [25]. Eight of the twelve patients experienced no dose-limiting toxicities on the lowest dose, with one of them showing a partial response of six months duration. Reversible farnesylation and radiosensitisation were demonstrated in a patient-derived cell line.

EGFR-The Epidermal Growth Factor Receptor (EGFR, also known as human EGF receptor 1 - HER1 or ErbB1) is a transmembrane glycoprotein with an intracellular tyrosine kinase domain. Binding of ligands to EGFR causes receptor homodimerisation or heterodimerisation, leading to phosphorylation of tyrosine residues on the intracellular domain, activating a downstream signalling cascade, including MAPK (cell proliferation), PI3K/Akt (cell cycle progression and survival), and the signal transducer and activator of transcription (STAT) family of proteins (cell division, survival, motility, invasion and adhesion) [26]. Mechanisms that lead to aberrant receptor activation include receptor overexpression, gene amplification, activating mutations, overexpression of receptor ligands, and/or loss of their negative regulatory mechanisms [27,28]. EGFR and its ligands EGF and TGF- $a$ are overexpressed in pancreatic cancer [29-31], and are associated with tumour aggressiveness [32].

Erlotinib (Tarceva or OSI-774) is an orally active small molecule that binds to the adenosine triphosphate (ATP) binding site on the intracellular tyrosine kinase domain of EGFR. EGFR transactivation of HER3 (ErbB3) mediates Akt signalling, and that coexpression of HER-3 with EGFR contributes to erlotinib sensitivity for pancreatic tumours [33,34].

Administration of an EGFR tyrosine kinase inhibtor (PKI166) in mice showed inhibition of tumour-induced angiogenesis and increase apoptosis of tumour-associated endothelial cells [35]. A phase III trial has been completed recently for erlotinib in combination with gemcitabine in 569 patients with advanced pancreatic cancer [36]. MS in the erlotinib/ gemcitabine arm was better at 6.24 compared to 5.91 months in the placebo/gemcitabine arm, with one-year survivals of $23 \%$ and $17 \%$ respectively $(\mathrm{p}=0.023)$. More patients on erlotinib had disease stabilisation. This was the first trial to show a survival benefit and the United States Food and Drug Administration (FDA) has already approved the use of this combination in 2005. European registration is restricted to those with metastatic but not locally advanced disease. The most frequent toxicities are diarrhoea and rash, with the latter being associated with better outcome. In patients with gemcitabine-refractory advanced 
pancreatic cancer, treatment with capecitabine and erlotinib was associated with an overall objective radiologic response rate of $10 \%$ and a MS of 6.5 months [37].

Gefitinib (Iressa or ZD1839) is another EGFR tyrosine kinase inhibitor that also inhibits anchorage-independent growth and invasiveness of pancreatic cancer cells [38]. Sensitivity to gefitinib is correlated directly with ligand (TGF-a) expression [39]. A phase II trial combining gemcitabine with gefitinib in patients with inoperable or metastatic pancreatic cancer has shown results similar to those of gemcitabine with erlotinib [40]. However phase II trials of capecitabine or docetaxel with gefitinib as second line therapy for patients with advanced pancreatic cancer were unimpressive [41-43]. Lapatinib (GW572016) has shown promising phase I results $[44,45]$ and is now being tested in a phase II trial with gemcitabine.

MEK-As discussed above, the Ras/Raf/MEK pathway plays a central role in mediating the transmission of growth-promoting signals in pancreatic cancer. ARRY-142886 (AZD6244), an orally active inhibitor of MEK-1 and MEK-2, caused tumour regression in a human pancreatic cancer cell line BxPC-3 xenograft model [46]. Another inhibitor, CI-1040 (PD184352) was tested in a phase II study of 67 patients (15 with pancreatic cancer) [47]. No significant antitumour activity was demonstrated.

PI3/Akt Pathway-The phosphatidylinositol-3-kinase (PI3K)/Akt pathway plays a role in cell proliferation, survival and resistance to apoptosis [48,49]. Class $1 \mathrm{~A}$ PI3Ks are composed of heterodimers of an inhibitory adaptor/regulatory (p85) and a catalytic (p110) subunits [50]. Akt2 (also known as protein kinase B $\beta$ ), the human homologue of the viral oncogene $\mathrm{V}$-akt, is amplified in $20 \%$ of pancreatic cancers and its suppression by antisense RNA reduced growth and tumourigenicity [51,52]. Upon activation by EGFR or ras, PI3K activates Akt which in turn has multiple downstream targets, including mammalian target of rapamycin (mTOR) which regulates cell growth and metabolism in response to environmental cues [53], and the transcription factor nuclear factor kappa B (NFkB) which promotes cell growth, angiogenesis and invasion [54,55]. Phosphatase and tensin homologue deleted from chromosome 10 (PTEN) dephosphorylates the $3^{\prime} \mathrm{OH}$ group phosphorylated by $\mathrm{PI} 3 \mathrm{~K}$, acting as a tumour suppressor.

PI3K inhibitors such as wortmannin and LY294002 induced apoptosis of pancreatic cancer cell lines that display constitutive Akt phosphorylation (Panc-1, MIAPaCa-2, HPFA, Colo-357-L3.6pl, Capan-2 and CFPAC-1), but not in cells that did not (AsPC-1, BxPC-3 and Hs766T). In vivo exposure of Colo-357-L3.6pl in nude mice to LY294002 led to the inhibition of tumour growth and reduction in hepatic metastases [56]. Wortmannin also showed significant antitumour effect in a PK1 murine xenograft model when combined with gemcitabine [57].

RASN17 is a dominant negative mutant of ras that inhibits PI3K/Akt pathway upstream of PI3K, whilst AAA-AKT is a dominant negative mutant of Akt. Overexpression of these inhibitors induced apoptosis and abolished anchorage-independent growth of pancreatic cancer cells. Adenoviral vector carrying RASN17 also produced significant antitumour effect in vivo in mice bearing HPAF tumours [58].

The mTOR inhibitor temsirolimus (CCI-779) was found to have a significant antitumour effect in vivo when combined with gemcitabine, both in AsPC-1 subcutaneous and SUIT-2 peritoneal dissemination xenograft models [59]. Everolimus (RAD001) is an mTOR inhibitor that also downregulates the antiapoptotic protein survivin. Given before survivin siRNA, there was enhanced cell death in vitro in the pancreatic cancer cell lines MIAPaCa-2, BxPC-3, AsPC-1 and Panc-1 [60]. Sirolimus (rapamycin) was shown to be 
active against mTOR, hypoxia-inducible factor-1a (HIF-1 a) and vascular endothelial growth factor (VEGF), and inhibited the growth of SW1990 human pancreatic cancer cells in vivo [61]. These are currently being tested in phase II trials.

Proteosomes are enzymes that degrade multiple intracellular proteins, such as $\mathrm{I} \kappa \mathrm{B}$ (an endogenous inhibitor of $\mathrm{NF} \times \mathrm{B}$ ), cyclin-dependent kinase inhibitors p21 and p27, cyclins and p53 [62]. Bortezomib (Velcade or PS-341) is a proteosome inhibitor that promotes apoptosis $[63,64]$ and increases cell sensitivity to chemotherapeutic agents [65]. Given after gemcitabine it resulted in significant induction of apoptosis and long-term growth inhibition of MIAPaCa-2 cells in vitro [66]. Given in vivo it enhanced the effect of docetaxel on MIAPaCa-2 and L3.6pl by cell growth arrest and inhibition of angiogenesis [67]. Bortezomib in combination with irinotecan showed impressive antitumour activity in mice bearing BxPC-3 xenografts [68]. When used in conjunction with HA14-1, an inhibitor of $\mathrm{Bcl}-2$ (an antiapoptotic protein expressed in $23 \%$ of invasive ductal adenocarcinomas of the pancreas [69]), increased oxidative stress and apoptosis was noted on BxPC-3 cells [70]. Completed phase I trials of bortezomib in combination with chemotherapy for solid tumours have shown promising results [71-73]. Another oral proteosome inhibitor, NPI-0052 resulted in significantly enhanced antitumour response when combined with either gemcitabine or cetuximab in a Panc-1 murine xenograft model [74].

Genistein is a naturally occurring isoflavone present in soybeans, and is believed to protect people who consume a diet high in soy products from pancreatic cancer. It inhibits cancer cell growth and angiogenesis, induces apoptosis, and chemosensitises cells by inhibition of PI3K/Akt/NFkB and Notch signalling [75-79]. Pre-treatment of pancreatic cancer cells with genistein followed by either gemcitabine [80] or cisplatin [81,82] potentiated the effect of the chemotherapeutic agent both in vitro and in vivo. Significant growth inhibition and apoptosis was also demonstrated when genistein is combined with erlotinib in BxPC-3, Capan-2 and AsPC-1 cells, whilst in Colo-357 cells the addition of gemcitabine (triple therapy) significantly improved treatment efficacy [83]. As one of the functions of NFKB is to activate Bcl-xL (an antiapoptotic protein expressed in $90 \%$ of invasive ductal adenocarcinomas of the pancreas [69]), it has been shown that pre-treatment of pancreatic cancer cells in vitro with genistein followed by the Bcl-xL inhibitor BL-193 significantly inhibited cell growth [84].

Curcumin (diferuloylmethane), derived from the spice turmeric (Curcuma longa), is a nontoxic agent that inhibits $\mathrm{NF} \times \mathrm{B}$ and therefore the expression of NFкB-regulated gene products, including Bcl-2, Bcl-xL, cyclooxygenase-2 (COX-2), cyclin D1, VEGF, survivin, interleukin-8 (IL-8) and matrix metalloproteinase-8 (MMP-8) [85,86]. Curcumin was able to inhibit proliferation and induce apoptosis in pancreatic cancer cells in vitro $[85,87,88]$. The antitumour activity of gemcitabine was also potentiated by curcumin, both in vitro and in vivo (orthotopic mouse model with MIAPaCa-2 cells) [85,89]. ApoG2, a small molecule inhibitor of Bcl-2 and Bcl-xL, showed enhanced antitumour effect in BxPC-3 cells after pretreatment with curcumin [90]. In a phase II trial of patients with advanced pancreatic cancer, oral curcumin was well tolerated, and although has limited absorption, it was able to decrease the expression of tumour-promoting molecules including NFKB, COX-2 and phosphorylated STAT-3 in peripheral blood mononuclear cells. Of the 21 evaluable patients, one had a brief marked tumour regression [91]. A phase II trial with gemcitabine is ongoing.

Cyclooxygenase-The COX enzymes, COX-1 and COX-2, function to convert arachidonic acid into prostaglandins. COX-1 is constitutively expressed in normal tissues and plays a role in tissue homeostasis such as in the kidneys, gastric mucosa and platelets. COX-2 is inducible by growth factors, cytokines and tumour promoters [92]. It is upregulated in 44-90\% of pancreatic cancers [93-95]. The molecular mechanisms of COX- 
and prostaglandin-mediated pancreatic cancer development are complex, involving multiple mitogenic signalling pathways and molecules including PI3K/Akt, STAT, ERK1/2, tyrosine kinases and NFKB; regulators of cell migration, invasion and angiogenesis such as MMP-2 and VEGF; immune suppression by prostaglandins; and the production of free radicals and peroxidation of procarcinogens to carcinogens by COX-2 [92]. K-ras mutation is not correlated with COX-2 expression [96].

Evidence exists to suggest that COX inhibitors, or non-steroidal anti-inflammatory drugs (NSAIDs), can reduce the risk of developing pancreatic cancer [97]. NSAIDs were able to suppress proliferation of pancreatic cancer cell lines in vitro predominantly through cell cycle arrest and induction of apoptosis, as well as inhibit angiogenesis in vivo [96,98-102]. The antiproliferative effect was enhanced by gemcitabine. Phase II trials using gemcitabine in combination with celecoxib (Celebrex) 400mg twice daily, a selective COX-2 inhibitor, have shown promising results. For 20 evaluable patients with metastatic pancreatic cancer, the MS was 6.2 months and the three-month survival rate was $72 \%$ [103]. In another study of 32 patients with locally advanced and metastatic disease, the reported MS was 9.1 months [104]. Celecoxib, gemcitabine and irinotecan were also tested in 20 patients with advanced pancreatic cancer [105]. Of the 17 evaluable patients, the MS was 13 months and the oneyear survival rate was $64 \%$, associated with improvement of pain and quality of life and reduction in CEA and CA19-9. Celecoxib in combination with cisplatin and fixed-dose rate infusion of gemcitabine in 22 patients with metastatic disease did not show any clinical benefit [106]. In a separate phase II study of 20 patients with advanced disease progressing after gemcitabine, the combination of celecoxib and infusional 5-FU was well-tolerated, induced two partial responses, significantly reduced CA19-9 in three of nine evaluable patients, leading to a MS of 14 weeks [107]. Study of celecoxib with capecitabine as a second line therapy revealed a MS of 16 weeks, with seven of 19 patients having a $>25 \%$ decrease in CA19-9 [108].

Curcumin was able to synergistically enhance the growth inhibitory effect of celecoxib in the P-34 pancreatic cancer cell line, mediated through the inhibition of COX-2 [109]. A phase III trial of gemcitabine, celecoxib and curcumin is currently in progress for patients with locally advanced and metastatic pancreatic cancers.

Gastrin-Cholecystokinin Receptor Pathway-Gastrin is a peptide hormone secreted by $\mathrm{G}$ cells of the gastric antrum and duodenum, and it can act as a growth factor for gastric, colonic and pancreatic cancers [110,111]. Cholecystokinin-B (CCK-B) receptor, gastrin precursors, and the fully-processed amidated gastrin is expressed in $95 \%, 55-91 \%$ and $23 \%$ of pancreatic cancers respectively, but not in the normal pancreas [112]. Both CCK-B and its splice variant CCK-C receptors bind to CCK and gastrin [113]. BxPC-3 cells transfected with the antisense DNA for CCK-C receptor showed a $65 \%$ decrease in cell numbers compared to control $(\mathrm{p}=0.002)$. When performed in vivo, tumours of treated nude mice were $75 \%$ smaller in volume and $83 \%$ reduced in weight $(\mathrm{p}=0.03)$ [113].

Gastrazole (JB95008), a selective CCK-B receptor antagonist, was tested in two randomised controlled trials in patients with advanced pancreatic cancer [114]. In a trial of 18 patients using protracted venous infusion (PVI) gastrazole compared with PVI placebo, gastrazole significantly improved survival - MS of 7.9 and 4.5 months and one-year survivals of $33 \%$ and $11 \%$, respectively ( $\log$ rank $\mathrm{p}=0.02)$. In the other trial, 98 patients were randomised to compare PVI gastrazole and PVI 5-FU. There was no significant difference in survival between the two (MS of 3.6 and 4.2 months and one-year survivals of $13.2 \%$ and $26.2 \%$ respectively, $\log$ rank $\mathrm{p}=0.42$ ), but gastrazole caused less diarrhoea, stomatitis and hand-foot syndrome. 
Insulin-like Growth Factor and Focal Adhesion Kinase-Insulin-like growth factor (IGF) and its receptors have been extensively studied in various cancers such as colon, breast and prostate [115]. In particular IGF-1 receptor (IGF-1R), a transmembrane receptor tyrosine kinase, has anti-apoptotic and growth promoting effects, acting via multiple pathways including PI3/Akt, MAPK and the Janus kinase (JAK)/STAT3 pathways [116-118]. It can be inhibited by antibodies, antisense RNAs and dominant-negative mutants [119].

IGF-1R is overexpressed in 64\% of pancreatic cancer cells [120]. Adenoviral vectors carrying either the IGF-1R dominant negative inhibitor (Ad-IGF-Ir/dn) or short hairpin RNA for IGF-1R (Ad-shIGF-Ir) inhibited pancreatic cancer growth both in vitro and in vivo, and there was increased sensitivity to chemotherapy and radiation induced apoptosis [121]. AMG-479, a human anti-IGF-1R antibody, was recently tested in combination with gemcitabine and EGFR inhibitors in vivo [122]. In MIAPaCa-2 xenografts, AMG-479 was more effective in suppressing tumour growth when combined with gemcitabine than with either agent alone. For BxPC-3, AMG-479 showed additive effect when combine with EGFR inhibitors erlotinib, gefitinib and panitumumab. Inhibition of the PI3/Akt pathway was demonstrated.

NVP-TAE226, a dual focal adhesion kinase (FAK) and IGF-1R kinase inhibitor, showed tumour suppressive effect on MIAPaCa-2 cells in vivo [123]. FAK, expressed in 48\%-75\% of pancreatic cancers, is a non-receptor cytoplasmic tyrosine kinase involved in the regulation of cellular signalling, migration, apoptosis and cell cycle progression [124-127]. It is also associated with invasive potential. Gene silencing with RNAi promoted anoikis and inhibited metastasis of human pancreatic cancer in an animal model, as well as enhancing gemcitabine chemosensitivity [126].

Smad4 and TGF- $\beta$-Mutation or deletion of the Smad4 (MADH4) gene, originally designated as the tumour suppressor gene DPC4 (deleted in pancreatic carcinoma, locus 4) on chromosome 18q21.1, occurs in 55\% of pancreatic cancers [128]. It is a member of the Smad family of transcription factors, and Smad4 inactivation potentiates tumour growth, angiogenesis [129] and invasion [130,131] and is associated with poor prognosis [132]. Formation of a heteromeric complex between TGF- $\beta$ ligand and TGF- $\beta$ type I and type II receptors (T $\beta R I$ and T $\beta$ RII) leads to phosphorylation of cytoplasmic Smad2 and Smad3 proteins by T $\beta R I$ kinase, which in turn form heteromeric complexes with Smad4 [133,134]. Restoration of the Smad4 gene using an adenoviral vector showed inhibition of pancreatic tumour growth in mice, although oddly a significant effect on proliferation was not seen in vitro [131]. Suppression of tumour growth was mediated in part by the downregulation of VEGF and expression of gelatinases (involved in tumour growth, invasion, angiogenesis and promotion).

TGF- $\beta$ plays a complex role as it is tumour suppressive in epithelial cells, but can also promote invasion and metastasis during the later stages of carcinoma progression [135]. Mutations of T $\beta R I$ and T $\beta$ RII are found in $1 \%$ and $4 \%$ of pancreatic cancers respectively [136]. Knockdown of Smad4 resulted in TGF- $\beta$-induced cell cycle arrest and migration but not in TGF- $\beta$-induced epithelial-mesenchymal transition, which makes cells more migratory and invasive. TGF- $\beta$-based therapeutic strategies in cancer are in development [135]. The antisense oligonucleotide specific for human TGF- $\beta 2$ mRNA, AP 12009, was initially tested for use in high-grade glioma [137,138]. In laboratory studies, AP 12009 significantly reduced TGF- $\beta 2$ secretion in human pancreatic cancer cell lines (Hup-T3, Hup-T4, PaTu-8902), decreased proliferation by up to $76 \%$, blocked tumour migration, as well as reversed TGF- $\beta 2$-mediated immune suppression in which IL- 2 activated lymphokineactivated killer (LAK) cell cytotoxicity was increased up to 708\% [139]. Ongoing phase I/II 
studies for the treatment of pancreatic carcinoma, malignant melanoma and colorectal carcinoma have been reported to show promising results, with one advanced pancreatic cancer patient still alive 72 weeks after having experienced a complete response [140].

Hedgehog Signalling-Hedgehog ( $\mathrm{Hh}$ ) signalling specifies the pattern and structure of many tissues during embryonic development. There are three mammalian Hh proteins, namely Sonic (Shh), Indian (Ihh) and Desert hedgehog (Dhh) respectively. Activation of the Hh pathway is controlled by two transmembrane proteins, the tumour suppressor Patched (Ptc) or the oncogenic Smoothened (Smo) [141]. Ptc normally suppresses Smo, but binding of Hh to Ptc relieves this inhibition, leading to Smo activation of transcriptional response [142]. Shh is expressed in $70 \%$ of human pancreatic adenocarcinomas [143]. Although also found in premalignant lesions, it is not detectable in normal ductal epithelium. Ihh expression is increased 35-fold in pancreatic cancer compared to normal tissues [144]. Mechanisms of tumourigenesis include its effects on the cell cycle regulators cyclin D1 and $\mathrm{p} 21$, protection from apoptosis via the PI3K/Akt signalling and stabilisation of Bcl-2 and Bcl-xL, as well as its collaboration with activated K-ras $[145,146]$.

Cyclopamine binds to Smo and inactivates the Hh pathway. It inhibited cell growth in vitro and in vivo for a wide range of digestive tract tumours, including the pancreas [147]. Killing of pancreatic cancer cells in vitro by paclitaxel or radiation were enhanced by cyclopamine, but this was not seen with gemcitabine or cisplatin [148]. In an orthotopic pancreatic xenograft model, only one of seven cyclopamine-treated mice developed pulmonary micrometastases compared to controls in which all developed multiple macrometastases [149]. Addition of gemcitabine completely prevented metastasis whilst inhibiting tumour growth at the primary site. Cyclopamine also downregulates the expression of EGFR, and in vitro studies of this agent in combination with gefitinib showed that it profoundly reduced the growth of Panc-1, SUIT-2 and AsPC-1 cells [150].

GLI-1 is a transcription factor that mediates the Shh pathway. Its inhibition by a synthetic micro RNA (miRNA-GLI-1-3548) was reported to suppress proliferation and induce apoptosis in MIAPaCa-2 cells [151].

Notch Signalling-Notch signalling is important in the development of organs, affecting tissue proliferation, differentiation and apoptosis. There are four known Notch genes in mammals that encode for heterodimeric transmembrane receptors. Its ligands are from two families of proteins known as 'Delta' and 'Jagged' respectively. Activation leads to proteolytic cleavage of the Notch receptors by $\gamma$-secretase, releasing the cytoplasmic domain which migrates to the nucleus and binds to transcription factors such as CSL (CBF-1 in mammals, suppressor of hairless in Drosophila and LAG-1 in Caenorhabditis elegans).

Notch signalling has been shown to be a downstream event of ras, EGFR and TGF-a in pancreatic tumourigenesis [152,153]. It also promotes tumour neovascularisation [154]. Downregulation of Notch1 with siRNA inhibited cell growth and induced apoptosis in BxPC-3, HPAC and Panc-1 pancreatic cancer cells [155]. This also resulted in the reduction of NFאB, VEGF and MMP-9 with subsequent inhibition of cell invasion [156], as well as enhanced antitumour activity in combination with curcumin via NFKB inhibition [157]. Notch 3 is found in around $70 \%$ of pancreatic cancers and is associated with a more aggressive tumour phenotype [158,159]. Inhibition by siRNA downregulated Bcl-xL in BxPC-3 cells, whilst $\gamma$-secretase inhibitors (GSI and L-685,458) resulted in decreased proliferation of Panc-1, HPAF-2 and BxPC-3 cells [159]. 


\section{Oncogenes and Tumour Suppressor Genes}

CaSm-Cancer-associated Sm-like protein (CaSm), also known as human Sm-like protein (LSM1, hLsm1), is overexpressed in the majority of pancreatic cancers and encodes a $1.2 \mathrm{~kb}$ mRNA transcript, with the largest open reading frame encoding a 133 amino acid protein that contains two Sm motifs found in the common small nuclear RNA proteins and the LSm family of proteins $[160,161]$. LSm family of proteins are involved in mRNA decapping and degradation [162]. Antisense CaSm RNA was able to alter the transformed phenotype of pancreatic cancer cells by reducing their ability to form large colonies in soft agar [160]. An adenoviral vector engineered to express $\mathrm{CaSm}$ antisense RNA (Ad-aCaSm) significantly inhibited tumour growth both in vitro and in vivo primarily by disrupting cell cycle progression, and the antitumour effect was further enhanced by gemcitabine [163]. Systemic administration of Ad-aCaSm also resulted in a reduction of the number of hepatic metastases and an increased survival time of mice bearing the murine pancreatic cell line Panc02 [164]. The antitumoral efficacy was dependent on both direct and bystander mechanisms.

BIRC5 (Survivin)-Survivin is a $16.5 \mathrm{kDa}$ protein encoded by a gene known as BIRC5 (Baculoviral Inhibitor of Apoptosis Repeat-Containing 5) on the telomeric position of chromosome 17. It functions as an antiapoptotic and cell cycle regulatory protein by blocking the common downstream effectors of both the intrinsic mitochondrial and the extrinsic membrane death receptor pathways, namely caspases-3, -7 and -9 [165]. Survivin is expressed in more than $80 \%$ of pancreatic cancers, some premalignant lesions but not in non-neoplastic pancreatic tissues [166-168], and is associated with poor clinical outcome [168-170].

When pancreatic cancer cell lines were irradiated, survivin mRNA expression was upregulated to induce increased radioresistance [171]. siRNA treatment could improve the radiosensitivity of AsPC-1 cells [172,173]. It also inhibited growth and induced apoptosis in Panc-1 and PC-2 cells $[173,174]$. The survivin antisense oligonucleotide (LY2181308) was able to produce significant antitumour activity in human xenograft tumour model in mice [175].

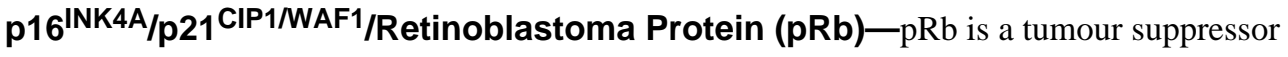
gene that regulates the $\mathrm{G} 1$ to $\mathrm{S}$ checkpoint of the cell cycle [176]. In response to mitogenic signals, cyclin D is upregulated which in turn activates cyclin D-dependent kinases 4 and 6 (CDK4 and 6). This leads to the phosphorylation of $\mathrm{pRb}$, resulting in the release of transcription factor E2F, therefore inducing the expression of genes needed for DNA synthesis. pRb can also be phosphorylated by cyclin E-dependent kinase 2 (CDK2) in late G1 phase. $\mathrm{p} 16^{\mathrm{INK} 4 \mathrm{~A}}$ binds and inactivates CDK4/6, whilst $\mathrm{p} 21^{\mathrm{CIP} 1 / \mathrm{WAF} 1}$, induced by $\mathrm{p} 53$, inhibits CDK2.

The $\mathrm{p} 16^{\mathrm{INK} 4 \mathrm{~A}}$ (MTS1) gene on chromosome 9p21, is deleted in $85 \%$ of pancreatic adenocarcinomas [177]. p16-mediated cytotoxicity is tightly associated with the presence of functional $\mathrm{pRb}$ [178]. This is advantageous for gene therapy in pancreatic cancer as only $6 \%$ showed mutant $\mathrm{pRb}$ [179]. E1 and E3-deleted adenovirus 5 containing p16 (AdexCACSp16) induced a high level of p16 mRNA expression in MIAPaCa- 2 cells, significantly suppressing cell proliferation [180]. When infected with a replication-defective adenovirus containing the $\mathrm{p} 21^{\mathrm{CIP} 1 / \mathrm{WAF} 1}$ gene (rAd-p21), HPAC and Hs766T cells showed significant growth inhibition in vitro [181].

p53-The tumour suppressor gene p53, located on chromosome $17 \mathrm{p}$, is inactivated by mutation in 50-75\% of pancreatic adenocarcinomas [182]. It encodes a transcription factor 
that is upregulated and activated upon stress such as DNA damage [176]. It can induce apoptosis or G1 cell cycle arrest via p2 ${ }^{\mathrm{CIP} 1 / \mathrm{WAF} 1}$. It is normally maintained at a very low level by mdm2 (murine double minute) which targets p53 for ubiquitin-mediated degradation. Stress or mitogenic signals increase the level of $\mathrm{p} 14{ }^{\mathrm{ARF}}$ which in turn inhibits mdm2, leading to the stabilisation and activation of p53. Recently it was discovered that the DNA damage-induced p53 response is dispensable for tumour suppression, but instead p19ARF, induced by oncogenic disruption of the cell cycle, plays a crucial role [183].

The first gene therapy for the treatment of cancer was approved in China in 2004, where Gendicine (SiBiono GeneTech, Shenzen, China), a replication-defective adenovirus 5 expressing p53 is used for squamous cell carcinoma of the head \& neck [184]. In pancreatic cancer, transfer of p53 using a similar vector (Ad5/CMV/p53) suppressed the growth of human pancreatic cancer cell lines AsPC-1, BxPC-3, Capan-1, CFPAC-1, MIAPaCa-2 and Panc-1. Suppression of tumour growth mediated by apoptosis was observed in nude mouse subcutaneous tumour model [185]. A retroviral p53 vector inhibited growth of primary as well as peritoneal deposits of BxPC-3 in mice [186]. Reintroduction of p53 using adenoviral vector to cells previously treated with gemcitabine increased cytotoxicity both in vitro and in vivo, although this effect was not seen with cisplatin [187].

Thoc1/p84 (also known as hHpr1 or p84N5), a protein that localises in the subnuclear regions associated with RNA processing, binds to $\mathrm{pRb}$ [188]. A recent study found that infection of pancreatic adenocarcinoma with adenovirus encoding p53 and Thoc1/p84 inhibited growth in vitro and in vivo to a greater extent than treatment with either one alone [189].

p73 - p73, localised on chromosome 1p36, is a proapoptotic gene of the p53-gene family observed in $45.6 \%$ of pancreatic adenocarcinomas [190]. Overexpression of p73 is inversely linked to lymph node metastasis and tumour size. It can induce cell cycle arrest and apoptosis in a p53 manner. An adenoviral vector that encodes p73 was capable of effective killing of several pancreatic cancer cell lines, including those that were completely resistant to p53-mediated apoptosis [191].

\section{Suicide Gene Therapy}

Also called gene-directed prodrug activation therapy, suicide gene therapy is a two-step process. First a gene is delivered to the tumour that will lead to the expression of an enzyme. A prodrug is subsequently administered that is activated selectively by this enzyme.

\section{Herpes Simplex Virus Thymidine Kinase (HSV-tk)/Ganciclovir-The HSV-tk/} ganciclovir approach is the most well-known example of suicide gene therapy. HSV-tk is able to monophosphorylate the guanosine analogue ganciclovir, which is subsequently converted by cellular guanylate kinases to the triphosphorylated forms, blocking DNA synthesis and inducing cell death [192]. The therapeutic effect is also based on a "bystander effect" whereby HSV-tk transduced tumour cells are toxic to nearby neighbouring unmodified tumour cells. This method, delivered by a retroviral vector, seemed to be effective in inhibiting the growth of the human pancreatic cancer cell line SW1990 in vitro [193]. Similar results were also found both in vitro and in vivo for DSL-6A/C1 rat pancreatic carcinoma cells with HSV-tk transduced retro- and adeno-virally [194], as well as in nude mice bearing human pancreatic cancer cells intraperitoneally after treatment with Ad-HSV-tk [195]. Murine pancreatic tumour, injected into the liver, displayed significant tumour volume reduction and necrosis after intratumoural injection of HSV-tk-bearing adenoviruses followed by intraperitoneal ganciclovir administration [196]. An in vivo study showed that the combination of adenovirus- and retrovirus-mediated delivery of HSV-tk 
appeared to be more effective in tumour reduction compared to either one alone [197]. Liposome-mediated transfer of HSV-tk caused regression of tumours in nude mice with peritoneal dissemination of the human pancreatic cancer cells PSN-1 [198]. Other studies, however, indicated that retrovirally transduced HSV-tk has limited efficacy in human pancreatic cell lines both in vitro and in vivo [199,200].

Cytosine Deaminase-Cytosine deaminase is a bacterial enzyme that converts the prodrug 5-fluorocytosine (5-FC) into the cytotoxic and radiosensitising agent 5-FU. A replication-defective adenovirus carrying the $\mathrm{CD}$ gene was found to inhibit the growth of the murine pancreatic cancer cell line Panc02 both in vitro and in vivo when given together with 5-FC [201]. Similar results were also demonstrated for PaTu-8988 and SW1990 cells in vitro [202,203]. A phase I trial of this virus, injected intratumourally under ultrasound guidance, is being tested with chemoradiotherapy in patients with non-metastatic pancreatic adenocarcinoma. A retrovirus with the $\mathrm{CD}$ gene linked to the oncogene ErbB2 promoter, enhanced cell-killing with 5-FC in ErbB2-positive pancreatic cancer cells [204].

FCY1 and FUR1 are genes encoding for CD and uracil phosphoribosyltransferase (UPRT) respectively. They are derived from the yeast Saccaromyces cerevisiae. As some cells are relatively resistant to 5-FU, UPRT has an additional advantage as it catalyses the conversion of 5-FU into the toxic metabolite 5-fluorouridine- $5^{\prime}$-monophosphate [205]. The results of a recent in vitro study of these genes, transfected using plasmid vectors into human pancreatic cancer cell lines, were however far from impressive [206]. FCY1 alone was ineffective. In combination with FUR1, only some showed increased sensitivity to 5-FC. In another study of an E1B-55kDa-deleted adenovirus carrying the UPRT gene (AxE1AdB-UPRT) together with 5-FU, mice with peritoneal dissemination of AsPC-1 showed dramatic improvement without toxicity to normal tissues [207].

Nitroreductase-The Escherichia coli enzyme nitroreductase (NTR) is able to reduce the prodrug CB1954 (5-[aziridin-1-yl]-2,4-dinitrobenzamide) to 2- and 4-hydroxylamino derivatives, the latter then reacts with cellular thio- esters to generate a potent alkylating agent capable of cross-linking DNA [208]. In contrast to HSV-tk/ganciclovir and CD that work by inhibiting DNA synthesis, NTR/CB1954 is also toxic to non-replicating tumour cells. Pancreatic cancer cell lines (SUIT-2, BxPC-3 and AsPC-1) expressing the NTR gene (introduced retrovirally) showed increased sensitivity to CB1954 (up to 500-fold in SUIT-2), with associated bystander effect [209]. In nude mice bearing subcutaneous NTRexpressing human pancreatic cancer cells, CB1954 administration resulted in tumour regression, growth delay and increased MS [210]. In a murine xenograft model with peritoneal dissemination of SUIT-2, administration of a replication-defective adenoviral vector containing the NTR gene (Ad-CMV-ntr) in combination with CB1954 almost doubled MS from 14 to 26 days [211]. No clinical trial has yet been done in patients with pancreatic cancer.

\section{Antiangiogenic and Matrix Metalloproteinase Inhibitors}

\section{Antiangiogenic Inhibitors}

Tumour growth is dependent on angiogenesis, a process involving the vascular endothelial growth factor (VEGF) family of proteins and receptors. VEGF is a glycoprotein that promotes endothelial cell survival, mitogenesis, migration, differentiation, and vascular permeability [212]. It is overexpressed in over $90 \%$ of pancreatic cancers and is associated with increased microvessel density, tumour progression and poor prognosis [213]. The VEGF receptors, VEGFR-1 (FMS-like tyrosine kinase-1 - Flt-1) and VEGFR-2 (foetal liver kinase-1 - Flk-1 or kinase insert domain receptor - KDR) are also overexpressed in the vasculature of tumours that express VEGF [214]. Growth factors such as EGF, TGF-a, 
TGF- $\beta$, platelet-derived growth factor (PDGF), and the cytokines IL-1a and IL-6, can upregulate the expression of VEGF [215].

Soluble VEGFR-2-Soluble forms of VEGFR-1 and VEGFR-2 could inhibit VEGFdependent tumour angiogenesis, first by sequestering VEGF, and secondly by forming heteromeric complex with their wild-type receptor thus acting as a dominant negative [216]. A recombinant adenovirus encoding a soluble form of VEGFR-2 (Ad Flk1-Fc) showed significant antitumour effect when injected intravenously into mice bearing either Panc02 or BxPC-3 cancer cells [217]. A truncated dominant negative mutant of VEGFR-2, when delivered via replication-defective retroviruses, resulted in inhibition of tumour growth in each of three human pancreatic cancer cell lines in vivo [218].

AS-3-AS-3 is a VEGF antisense oligonucleotide that has been tested in mice with the human pancreatic cancer cell lines AsPC-1 or HPAF-2 implanted into the pancreas [219]. AS-3 normalised plasma VEGF level, decreased angiogenesis, reduced tumour growth and metastasis with subsequent improved survival. None of the treated animals developed ascites, suggesting a reduction in vascular permeability caused by decreased VEGF.

PTK 787 (ZK222584) and SU5416—Blockade by the VEGF tyrosine kinase inhibitor PTK 787 has been shown to hinder the growth of L3.6pl pancreatic cancer xenograft by inhibiting angiogenesis, cell proliferation and increased apoptosis. When combined with gemcitabine, there was significant reduction in lymph node and hepatic metastases and increase in survival $[220,221]$. SU5416, a selective inhibitor of VEGFR-2 tyrosine kinase, produced a significant antitumour effect in vivo on MIAPaCa-2 cells, with an almost complete suppression of tumour growth and relapse when combined with gemcitabine [222].

ZD6474-ZD6474 is an orally active inhibitor of VEGFR-2 and EGFR tyrosine kinase. This was tested on mice bearing L3.6pl cancer cells [223]. ZD6474 decreased primary tumour growth, lymph node and hepatic metastases compared to treatment with gemcitabine alone. Antitumour effect was more marked when ZD6474 was given in combination with gemcitabine. ZD6474 has also been tested with ionising radiation and gemcitabine, both in vitro to MIAPaCa-2, Panc-1 and Capan-1 cells, and in vivo to MIAPaCa-2 tumour xenografts, with encouraging results [224].

Axitinib (AG-013736)—Axitinib is an orally active inhibitor of VEGFRs, as well as related tyrosine kinase receptors at higher concentration, namely PDGF receptor- $\beta$ (PDGFR$\beta$ ) and c-Kit [225]. In vivo studies have demonstrated that it has potent anti-angiogenic and anti-tumour activities [226-228]. In a recent phase II trial of 103 patients with advanced pancreatic cancer, the reported MS was 6.9 months when axitinib was given in combination with gemcitabine, compared to 5.6 months with gemcitabine alone [229]. It is currently in phase III trial.

Sorafenib (BAY 43-9006)-Sorafenib has an inhibitory effect on VEGF, PDGFR- $\beta$, cKit, raf-1 and Flt-3 that are important for tumour proliferation and angiogenesis [230]. It has been approved by the US FDA in 2005 for the treatment of advanced renal cell carcinoma. A phase II trial showed that although it was well-tolerated, it was inactive in patients with advanced pancreatic cancer [231]. A phase III trial is in progress.

NK4 \& ARQ 197-NK4 (natural killer transcript 4) is a synthetic competitive antagonist of hepatocyte growth factor (HGF) and an angiogenesis inhibitor [232]. HGF binds to the cMet-encoded receptor, which is overexpressed in 61-87\% of pancreatic cancers [233-235]. HGF is infrequently expressed by pancreatic cancer cells, but tumour-associated fibroblasts 
do produce HGF $[230,236,237]$. HGF promotes growth, enhances cell motility and extracellular matrix breakdown leading to invasion and metastasis of cancer cells. In pancreatic cancer mouse tumour model, NK4 suppressed tumour progression by inhibiting both angiogenesis and HGF-mediated invasion/metastasis [236], although the latter mechanism has been debated [238].

An NK4-expressing adenoviral vector (Ad-NK4) has been tested on pancreatic cancer cells both in vitro and in vivo. Ad-NK4 potently inhibited invasion of cancer cells in response to HGF [239]. Intrasplenic injection of Ad-NK4 suppressed the number and growth of hepatic metastases [240]. Intraperitoneal injection of Ad-NK4 suppressed the development of AsPC-1 tumour in a mouse peritoneal dissemination model [241]. In mice with orthotopically implanted SUIT-2 tumours, peritumoural injection of Ad-NK4 in combination with gemcitabine significantly reduced tumour volume compared to Ad-NK4 or gemcitabine alone [242]. Complete suppression of peritoneal dissemination and liver metastases was also noted, leading to improved survival of the animals.

ARQ 197, a c-Met receptor tyrosine kinase inhibitor, is currently in phase II trial. Phase I study showed that it was well tolerated, and of the 33 evaluable patients, two achieved partial response and 19 had stable disease [243].

TNP-470-TNP-470 (O-(chloroacetyl-carbamoyl) fumagillol) is an analogue of fumagillin derived from Aspergillus fumigatus that could inhibit the proliferation of endothelial cells [244]. Early studies on pancreatic cancer have shown that it is effective in inhibiting hepatic metastasis of human pancreatic cancer cells in mice following splenic injection, with or without cisplatin $[245,246]$. Significant inhibition of tumour growth, metastatic spread and angiogenesis has also been demonstrated in vivo for MIAPaCa-2, AsPC-1 and Capan-1, although survival was not statistically significant [247]. TNP-470 was tested with gemcitabine in nude mice with surgically implanted SW1990 cells in the tail of the pancreas [248]. When used alone, gemcitabine inhibited the growth of the primary tumour more significantly than TNP-470 alone, whereas tumour metastasis was better controlled with TNP-470. No significant improvement in survival rate was noted in these two groups. However when administered in combination, there were improved anti-tumour and antimetastatic effects as well as increased survival.

Cilengitide (EMD 121974)—Integrins are heterodimer transmembrane receptors composed of $\alpha$ and $\beta$ subunits responsible for cell adhesion to the extracellular matrix. They bind to ligands that include laminin, fibronectin, vitronectin, thrombospondin, fibrinogen and fibrin. Integrins play a role in angiogenesis where they are involved in endothelial cell migration, proliferation and survival [249]. aV $\beta 3$ induces angiogenesis via basic fibroblast growth factor or tumour necrosis factor-a (TNF-a), whereas aV $\beta 5$ achieves this via VEGF or TGF-a [250].

Cilengitide is an inhibitor of the integrins $\alpha \mathrm{V} \beta 3$ and $\alpha \mathrm{V} \beta 5$ [251]. In a phase II study of 89 patients, no significant response was noted [252]. The MS for cilengitide with gemcitabine was 6.7 compared to 7.7 months for gemcitabine alone, with overall response rates of $17 \%$ and $14 \%$ respectively.

\section{Matrix Metalloproteinase Inhibitors}

The interplay between pancreatic cancer cells and its surrounding tumour stroma plays an important role in tumour progression, affecting growth, angiogenesis, evasion of hose immune response, invasion and metastasis [253]. Degradation of the extracellular matrix by MMPs, a family of zinc-containing proteolytic enzymes, is essential for tumour spread and 
neovascularisation. The imbalance between activated MMPs and tissue inhibitors of MMPs is frequently found in pancreatic cancer [254].

Despite evidence on the effectiveness of various MMP inhibitors (MMPIs) on animal models [255-259], results of clinical trials have been disappointing. Marimastat is a synthetic broad-spectrum, orally active MMPI. Although well tolerated (musculoskeletal toxicity is the most severe side effect), it did not show any survival benefit for patients with advanced pancreatic cancer compared to gemcitabine or in combination [260,261]. Another MMPI, BAY 12-9566, was inferior to gemcitabine in a phase III trial [262].

\section{Oncolytic Virus}

Replication-selective oncolytic viruses are engineered to replicate specifically in and destroy tumour cells. Viruses kill cells by a number of mechanisms which include direct cell lysis, expression of toxic viral proteins, induction of antitumour immunity, and sensitisation to their effects. The first evidence of efficacy of oncolytic viral therapy was described in 1912 by DePace, when a patient with uterine cervical carcinoma experienced tumour regression after an attenuated rabies vaccination. Since then numerous types of oncolytic viruses have been evaluated as therapeutic agents, most notably adenoviruses [263].

\section{ONYX-015}

Adenovirus is a non-enveloped, icosahedral, double-stranded DNA virus of about 70-90nm in diameter, with a genome size of 34-48kb. ONYX-015 (d11520) is a replication-selective adenovirus type 5 with E1B-55kDa gene deletion. Normally the E1B-55kDa protein is able to bind and inactivate $\mathrm{p} 53$, an essential step for effective viral replication [264]. It is thought that as most tumours have lost the function of the p53 pathway, deletion of E1B-55kDa would enable ONYX-015 to selectively replicate in cancer cells but not in normal cells.

Promising laboratory results have led ONYX-015 to be the first replication-selective oncolytic virus to enter clinical trials and the world's first approved for head and neck cancer therapy. In a phase I trial, ONYX-015 was administered via CT-guided (22 patients) or intraoperative injection (one patient) into pancreatic primary tumours every four weeks until tumour progression [265]. Six patients showed 25-49\% tumour regression, 11 were stable, and five showed tumour progression. A phase I/II study of 21 patients was done to evaluate the use of endoscopic ultrasound-guided intratumoural injection of advanced pancreatic carcinomas with ONYX-015 and then in combination with systemic gemcitabine [266]. Two had partial progression, two had minor reponse, six had stable disease, and 11 progressed or had to go off the study because of treatment toxicity. Complications included infection and duodenal perforation from the rigid endoscope tip. Disappointingly in these trials, viral replication was not detectable on fine needle biopsy of the tumours, unlike other trials for head and neck cancers [267,268], liver metastases of colorectal carcinoma [269], and ovarian cancer [270].

However it is important to note that the interaction between E1B-55kDa and p53 is more complex than originally thought, because ONYX-015 could replicate in some tumour cells that retain the wild-type p53 [271]. It was later shown that tumour selectivity of ONYX-015 is determined not by $\mathrm{p} 53$, but by the export of late viral RNA, a function requiring E1B-55kDa in normal but not in tumour cells [272].

\section{Herpes Simplex Virus (HSV)}

HSV is a large, enveloped, double-stranded DNA virus with a genome size of approximately $152 \mathrm{~kb}$. There are two serotypes of HSV, namely HSV-1 and HSV-2. 
G207 is a replication-selective mutant of HSV-1 with deletions at both $\gamma 34.5$ loci and a lacZ reporter gene inserted in and thus disrupting the UL39 gene [273]. $\gamma 34.5$ prevents the shutoff of host protein synthesis in infected cells by interacting with cellular phosphatase-1a to dephosphorylate eIF-2 $a$, leading to the production of more progeny viruses from infected cells [264]. UL39 normally encodes for the infected cell protein 6 (ICP6), the large subunit of ribonucleotide reductase required in the biosynthesis of DNA. Given their functions, $\gamma 34.5$ - and UL39-deleted mutants are unable to replicate in normal cells but they can do so in actively dividing tumour cells. NV1020 is derived from HSV-1 and contains deletions in the endogenous thymidine kinase gene (HSV-tk) and in one of the two $\gamma 34.5$ genes. HSV-tk is normally needed for nucleic acid metabolism, therefore mutant virus is dependent on endogenous levels of this enzyme, which is found in high levels in replicating cells [264]. NV1020 however does contain an exogenous copy of the HSV-tk gene derived from HSV-2, thus maintaining its sensitivity to aciclovir and ganciclovir which would otherwise be lost with the disrupted HSV-tk gene. In vitro laboratory findings showed that G207 can replicate in and kill human pancreatic cell lines AsPC-1, MIAPaCa-2 and BxPC-3 [274]. In a separate study, both G207 and NV1020 were equally effective in lysing four human pancreatic cells in vitro [275]. For Hs766T flank tumours in athymic mice, tumour eradication was achieved in $25 \%$ of the animals with G207 and 40\% with NV1020 respectively.

OncoVEX ${ }^{\mathrm{GM}-\mathrm{CSF}}$ is a recombinant HSV-1 with $\gamma 34.5$ and ICP47 gene deletions, together with the human granulocyte-macrophage colony-stimulating factor (GM-CSF) gene inserted. ICP47 normally binds to the transporter associated with antigen processing (TAP) to prevent the delivery of peptides into the endoplasmic reticulum, where they bind to major histocompatability complex (MHC) class I molecules. The genetic alterations of OncoVEX ${ }^{\mathrm{GM}-\mathrm{CSF}}$ mean that it could replicate selectively in tumour cells whilst boosting the antitumour immune response. It will be tested in a phase I trial in patients with unresectable pancreatic cancer.

hrR3 (UL39 deleted, HSV-tk conserved) was tested on nude mice bearing peritoneal dissemination of the human pancreatic cancer cells SW1990 [276]. Long term survival was seen in $70 \%$ of mice receiving hrR3 and ganciclovir, $40 \%$ receiving hrR3 alone, and none of the untreated animals. In another study, hrR3 and R3616 ( $\gamma 34.5$ deleted) were given with gemcitabine to pancreatic cancer cell lines [277]. There was more cytotoxicity when each of the viruses was given in combination with gemcitabine in vitro, although viral replication was inhibited. In a murine model with peritoneal dissemination, R3616 with gemcitabine had a greater effect than R3616 alone, while hrR3 with gemcitabine had a weaker effect than hrR3 alone.

FusOn-H2, a mutant HSV-2 with deletion of the protein kinase (PK) domain of the viral ICP10 gene, has shown promising in vivo results for pancreatic cancer [278]. The PK domain is normally required for HSV-2 replication, where it binds and phosphorylates ras, leading to activation of the ras/MAPK/ERK pathway, as well as the expression and stabilisation of the transcription factor c-Fos [279]. FusOn-H2 can therefore replicate selectively in pancreatic cancer cells in which the majority have an activated ras signalling pathway. In mice bearing subcutaneous MPanc-96 tumours, a single intratumoural injection of FusOn-H2 completely eradicated the disease, whilst intraperitoneal injection cleared established orthotopic tumours in $75 \%$ of the mice and completely prevented local metastasis.

The US3 gene encodes a serine/threonine protein kinase that protects cells from apoptosis [280]. L1BR1 is a US3 locus-deficient HSV-2 mutant. When tested on mice bearing SW1990 tumours, L1BR1 showed significantly better antitumour effect compared to hrR3 and R3616 ( $\gamma 34.5$ double-deletion mutant) [281]. It also showed the lowest replication 
capacity in normal human hepatocytes, and enhanced tumour apoptosis in vitro (SW1990, Capan-2 and BxPC-3) in combination with cisplatin and 5-FU.

The agent d120.surv is a recombinant HSV-1 that contains a survivin promoter driving the expression of ICP4, a major transactivating factor for viral genes. This makes replication of the virus restricted to survivin-expressing cancer cells. In vitro cytotoxicity was significantly higher in AsPC-1 (high survivin expression) compared to Panc-1 (low survivin expression) [282].

\section{Reovirus}

Reovirus is a non-enveloped, double-stranded RNA virus that normally causes subclinical infection in humans. Replication of reovirus requires an activated ras signalling pathway [283]. Normally when reovirus infects a cell, the intracellular host defence system is activated by the RNA-activated protein kinase (PKR). This leads to PKR autophosphorylation, followed by phosphorylation of eIF-2a, which in turn inhibits protein synthesis, thus preventing viral replication. However in cells with activated ras, PKR phosphorylation is blocked.

Reovirus was able to infect human pancreatic cancer cells Panc-1, MIAPaCa-2, PK-1, PK-9 and BxPC-3 in vitro [284]. In nude mice bearing Panc-1 and BxPC-3, tumour growth was inhibited by intratumoural injection, whilst local injection also had systemic antitumour effect in a bilateral xenograft model. Immunohistochemical staining showed viral replication in tumour but not in the surrounding normal tissue. In a separate study of pancreatic hepatic metastases in hamster, intraportal administration of reovirus significantly reduced the size and number of tumours [285].

\section{Immunotherapy}

In the first attempt of cancer immunotherapy, William Coley in the 1890s injected bacterial components into the tumours of his patients, activating the immune system which contributed to tumour cell rejection. In 1967 Lindenmann and Klein discovered that vaccination of mice with influenza virus-infected tumour cells showed antitumour response to non-infected parental cells, suggesting that the immunogenicity of host cell components was greatly increased by incorporation into the makeup of the virus [286]. Compelling evidence now suggests that the immune system plays an important role in the control of malignancy [287], and immunotherapy is widely considered as the most important and rapidly growing area of cancer research. Passive immunotherapy includes the use of antitumour agents that have been generated in vitro, such the use of antibodies or effector cells, whereas active immunotherapy aims to stimulate an antitumour response in vivo by means of vaccination.

\section{Antibodies}

Anti-EGFR Antibodies-Cetuximab (Erbitux or IMC-C225) is a chimeric monoclonal antibody generated from fusion of the variable region of the murine anti-EGFR monoclonal antibody M225 and the human $\mathrm{IgG}_{1}$ constant region. Promising laboratory results have led cetuximab to be tested in clinical trials. However a recent phase III trial of 766 patients with locally advanced or metastatic pancreatic adenocarcinoma failed to demonstrate any significant benefit (MS of 6 months with gemcitabine vs 6.5 months in combination with cetuximab, $\mathrm{p}=0.14$ ) [288]. The corresponding PFS was 3 and 3.5 months respectively $(\mathrm{p}=0.058)$. In an ongoing phase II trial with trimodal therapy of cetuximab, gemcitabine and intensity modulated radiotherapy (IMRT) for patients with locally advanced pancreatic cancer, there was no increase in toxicity profile [289]. One-year survival was 57\% whilst 
MS has not been reached. Of the 36 patients 12 showed partial remission, 20 had stable disease, and 4 had progressive disease. Combination of cetuximab, gemcitabine and radiotherapy caused the most growth inhibition on MIAPaCa- 2 and BxPC-3 cells when compared to single or double combination therapy [290].

Matuzumab (EMD72000) is a humanised $\operatorname{IgG}_{1}$ monoclonal antibody to the human EGFR. Laboratory studies have shown promising inhibitory effects on tumour growth and angiogenesis, including L3.6pl in an orthotopic rat model [291]. In a phase I study of combined treatment with matuzumab and gemcitabine, eight out of 12 patients with advanced pancreatic adenocarcinoma showed partial response or stable disease [292]. It appeared to be well tolerated.

Anti-VEGF Antibody-Bevacizumab (Avastin) is a recombinant humanised anti-VEGF monoclonal antibody. Despite promising phase II results [293], the recent phase III CALGB 80303 trial did not show any survival benefit of bevacizumab/gemcitabine combination compared to gemcitabine alone in 602 patients with advanced pancreatic cancer (MS of 5.7 vs 6 months) [294]. The AviTa phase III trial that examined treatment with gemcitabine plus erlotinib with either bevacizumab or placebo, has been closed. Bevacizumab however, may have a role in palliative treatment of chemotherapy-resistant pancreatic cancer. In a case report, a patient with stage IV disease initially unresponsive to gemcitabine, 5-FU, irinotecan and cisplatin subsequently responded with the addition of bevacizumab [295].

Anti-MUC1 Antibodies-MUC1 (mucin-1, CD227) is a polymorphic, glycosylated type I transmembrane protein expressed on glandular epithelium including the pancreas, breast, lung and gastrointestinal tract. It is overexpressed in $90 \%$ of pancreatic cancers and aberrantly glycosylated [296,297]. It inhibits cell-cell and cell-stroma interactions and functions as a signal transducer in the progression of cancer, including tumour invasion and metastasis [298]. Evidence suggests that circulating anti-MUC1-IgG antibodies is a favourable prognostic factor for pancreatic cancer [299]. Down-regulation of MUC1 expression in S2-013 human pancreatic cancer cell line by RNAi significantly decreased proliferation in vitro and in nude mice [300]. Adhesion of MUC1-suppressed cells to type IV collagen and fibronectin was slightly increased, and adhesion was slightly decreased to type I collagen and laminin. Implantation of these cells into the caecum or pancreas showed significant reduction of lymph node, pulmonary and peritoneal metastases. Similarly, siRNA towards MUC1 reduced cell proliferation and enhanced sensitivity to genotoxic drugs in MIAPaCa-2 and Capan-1 cells, whilst the overexpression of MUC1 in the normally low MUC1-expressing BxPC-3 cells caused high proliferation with low basal apoptosis [301].

${ }^{90}$ Yttrium-labelled PAM4 monoclonal antibody that recognises MUC1 was studied in combination with gemcitabine as a radiosensitiser in mice bearing Capan-1 [302]. There was increased inhibition of tumour growth and prolonged survival of the animals. It is currently undergoing phase I trial for patients with stage III or IV pancreatic cancer. ${ }^{213} \mathrm{Bi}-\mathrm{C} 595$ is an antibody targeting the protein core of MUC1, conjugated with the a-particleemitting ${ }^{213}$ bismuth. In vitro study showed that ${ }^{213} \mathrm{Bi}-\mathrm{C} 595$ was specifically cytotoxic to MUC1-expressing pancreatic cancer cells in a concentration-dependent manner compared to controls [297].

Anti-mesothelin Antibodies-Mesothelin is a 40kDa protein present on normal mesothelial cells of the pericardium, pleura and peritoneum, but is overexpressed in mesotheliomas, pancreatic and ovarian cancers [303]. Detected in 90-100\% of pancreatic adenocarcinomas [304,305], diagnosis by fine-needle aspiration biopsies using mesothelin as a marker has a sensitivity of $68 \%$ and specificity of $90 \%$ [306]. 
SS1P is a recombinant immunotoxin that consists of an anti-mesothelin Fv (SS1) fused to PE38, a 38kDa portion of Pseudomonas exotoxin A. After binding to mesothelin and subsequent internalisation into cells, it inhibits protein synthesis and results in apoptosis. A phase I study showed that it was well tolerated with self-limiting pleuritis as the doselimiting toxicity, due to the binding of SS1P to normal mesothelial cells [307].

MORAb-009, a monoclonal antibody against mesothelin is being tested in a phase I trial of 11 patients (three had pancreatic cancer) [308]. One of them who had previously progressed on gemcitabine showed disease stabilisation on CT and a drop in CA19-9.

Anti-Ptc Antibody-Antibody against Ptc has been shown to suppress Hh signalling and proliferation of the human pancreatic cells Panc-1 and SUIT-2 [309].

RAV12-RAV12 is a chimeric $\operatorname{IgG}_{1}$ antibody against RAAG12, an N-linked carbohydrate epitope expressed in up to $100 \%$ of pancreatic adenocarcinomas, as well as the majority of gastric and colorectal cancers [310]. Intraperitoneal injection of RAV12 inhibited the growth of SU 86.86 pancreatic cancer cells in a subrenal capsule xenograft mouse model [310]. Preliminary data from an ongoing phase I study of patients with recurrent adenocarcinoma revealed that of the four patients with pancreatic cancer, one with advanced disease had a $>50 \%$ reduction in CA19-9 [311].

\section{Adoptive Cell Transfer}

Adoptive immunotherapy involves harvesting the patient's peripheral blood T-lymphocytes, stimulating and expanding the autologous tumour-reactive T-cells using IL-2 and CD3specific antibody, before subsequently transferring them back into the patient. Twelve patients with advanced pancreatic cancer who underwent resection, intraoperative radiotherapy and intraportal infusion of LAK cells with recombinant IL-2 had lower incidence of liver metastasis compared to controls (three of 12 vs ten of $15 ; \mathrm{p}<0.05$ ) [312]. There was no significant difference in overall survival, but more patients were alive three years later (36\% vs none).

Telomerase-Telomerase is a reverse transcriptase that contains a RNA template used to synthesise telomeric repeats onto chromosomal ends. Activation of telomerase and its maintenance of telomeres play a role in immortalisation of human cancer cells, as telomeres shrink after each cell division [313]. Telomerase activity is found in 92-95\% of pancreatic cancers [314,315], and is associated with increased potential of invasion and metastasis and poor prognosis [316,317]. Upregulation of telomerase may also be responsible for the development of chemotherapy resistance [318]. Adenovirus-mediated transduction of p53 gene inhibited telomerase activity in MIAPaCa-2, SUIT-2 and AsPC-1 cells, independent of its effect on apoptosis, cell growth and cycle arrest [319]. Antisense to the RNA component of telomerase seemed to increase susceptibility of Panc-1 cells to cisplatin [320]. Telomerase reverse transcriptase antisense oligonucleotide (hTERT-ASO) was found to inhibit the proliferation of BxPC-3 cells in vitro by decreasing telomerase activity and increasing apoptosis [321].

Adoptive transfer of telomerase-specific T-cells was studied in a syngeneic pancreatic tumour mouse model [322]. T-cells were produced in vitro by coculturing human lymphocytes with telomerase peptide-pulsed dendritic cells (DCs) or in vivo by injection of peptide with adjuvant into C57BL/6 mice. Animals treated with these T-cells showed significantly delayed disease progression. 
MUC1-Adoptive transfer of MUC1-specific cytotoxic T-lymphocytes (CTLs) was able to completely eradicate MUC1-expressing tumours in mice [323]. Intraportal infusion of in vitro MUC1-stimulated T-cells was performed in patients with pancreatic cancer, with subsequent inhibition of liver metastasis [324]. In a study of eleven patients with lung metastases (from colorectal, pancreatic, breast, lung, or melanoma primaries), effector cells were generated in vitro using cultured DCs, synthetic peptide, peripheral blood lymphocytes, IL-2 and anti-CD3 antibody [325]. A partial response of the lung metastases was observed in a patient with pancreatic cancer who received these cells stimulated with MUC1.

\section{Cytokines and Immunomodulators}

TNFerade-TNF-a is a multifunctional cytokine that has shown antitumour potency [326-328]. TNFerade Biologic (TNFerade) is a replication-deficient adenovirus carrying the gene for human TNF-a, regulated by a radiation-inducible promoter Early Growth Response (Egr-1). The latter would ensure maximal gene expression when infected tissue is irradiated [329].

TNFerade was effective in combination with radiation in a number of human xenograft models, including glioma [330], prostate [331], oesophageal [332] and radiation-resistant laryngeal cancers [333]. The multicentre phase II/III Pancreatic Cancer Clinical Trial with TNFerade (PACT) is currently ongoing and involved patients with locally advanced pancreatic cancer. Patients were given radiotherapy, 5-FU with or without CT-guided transabdominal injection of TNFerade. Preliminary data of 51 patients revealed that the oneyear survival increased from $28 \%$ to $70.5 \%$ with the addition of TNFerade, with MS of 335 and 515 days respectively [334].

Virulizin-Virulizin (Lorus Therapeutics Inc.) is a biological response modifier obtained from bovine bile [335]. It stimulates the expression of TNF- $a$ and activates macrophages, which subsequently activates natural killer cells via IL-12 [336,337]. Evidence exists to show that it also induces the production of IL-17E with resulting eosinophilia [338].

In vivo studies showed that Virulizin significantly inhibited the growth of human pancreatic cancer xenografts (BxPC-3, SU 86.86 and MIAPaCa-2) in nude mice, as well as potentiated the antitumour effect of gemcitabine and 5-FU [339,340]. A phase III trial was conducted to study the effect of gemcitabine with or without Virulizin in 434 chemotherapy-naïve patients with advanced pancreatic cancer [341]. MS was not significantly better for the gemcitabine and Virulizin group compared to gemcitabine with placebo (6.3 vs 6 months). However for stage 3 patients who received Virulizin in a salvage setting, a significant difference in survival was demonstrated (10.9 vs 7.4 months, $\mathrm{p}=0.017)$.

\section{Vaccines}

Vaccination involves administering an antigen that is unique for a particular type of tumour with the aim of stimulating tumour-specific immunity. Antigens could be delivered in the form of DNA or peptide, as well as tumour cells or antigen-pulsed DCs. Additional synergistic help is added to elicit a more vigorous and effective immune response, such as cytokines and immunostimulating adjuvants.

Whole-Cell-GM-CSF is one of a few cytokines that has shown significant antitumour effect in vivo [342]. It is an important growth factor for granulocytes and monocytes, and has a crucial role in the growth and differentiation of DCs, the most potent antigenpresenting cells (APCs) for triggering immune response. In vivo growth of AsPC-1 cells, 
retrovirally transduced with the GM-CSF gene, was inhibited and associated with increased survival of the nude mice, even in the mature T-cell-deficient condition [343].

Jaffee et al. conducted a phase I study using allogeneic GM-CSF-secreting whole-cell tumour vaccine for pancreatic cancer [342]. This is based on the concept that the localisation of GM-CSF in the implanted tumour environment together with the shared tumour antigen expressed by the primary cancer would effectively induce an antitumour immune response. In this study two pancreatic cancer cell lines (PANC 10.05 and PANC 6.03) were used as the vaccine, both genetically modified to express GM-CSF. 14 pancreatic cancer patients who had undergone pancreaticoduodenectomy eight weeks prior were given variable doses of the vaccine intradermally. Three of the eight patients who received $\geq 10 \times 10^{7}$ vaccine cells developed post-vaccination delayed-type hypersensitivity (DTH) responses associated with increased disease-free survival time, and remained disease-free for longer than 25 months after diagnosis. Side effects were mainly limited to local skin reactions at the site of vaccination. In a recently completed phase II study of 60 patients with resected pancreatic adenocarcinoma, patients received five treatments of $2.5 \times 10^{8}$ vaccine cells, together with 5-FU and radiotherapy [344]. The reported MS was 26 months, with a one- and two-year survival of $88 \%$ and $76 \%$ respectively.

\section{Peptide and DNA}

- Ras: As described earlier, mutated ras is highly prevalent in pancreatic cancer. A phase II study was done using mutant ras peptide-based subcutaneous vaccine in 12 cancer patients (five with fully resected pancreatic and seven with colorectal cancers). Five out of 11 patients showed showed $\geq 1.5$ fold increase in interferon- $\gamma$ (IFN- $\gamma$ ) mRNA copies in peripheral blood mononuclear cells. The pancreatic cancer patients showed a disease-free survival of $>35.2$ months and post-vaccination survival of $>44.4$ months [345].

Gjertsen et al tested an intradermal vaccine of APCs loaded ex vivo with synthetic ras peptide corresponding to the ras mutation found in the patient's tumour [346]. In this phase I/II study of five patients with advanced pancreatic cancer, two of them showed induced immune response. They also studied ras peptide in combination with GM-CSF in a phase I/ II trial involving 48 patients with pancreatic adenocarcinoma of variable stage [347]. Peptide-specific immunity was induced in 58\% of patients. Of patients with advanced disease, those who responded to treatment showed increased survival compared to nonresponders (148 and 61 days respectively; $\mathrm{p}=0.0002$ ).

As IL-2 is involved in T-cell-mediated immune response, a vaccine consisting of mutant ras peptide in combination with GM-CSF and IL-2 was tested in a phase II trial of 17 patients with advanced cancers (14 colorectal, one non-small cell lung and two pancreatic cancers) [348]. Of the six patients with positive immune response (by means of IFN- $\gamma$ mRNA copies), the MS and the median PFS were 39.9 and 17.9 months compared to 18.5 and 15.6 months for non-responders, respectively. Grade III toxicities led to IL-2 dose reduction in three of the patients.

Evidence showed that patients vaccinated with ras peptide developed immunological memory. In a follow-up study of 23 patients vaccinated in 1995-98, the only five survivors were all immune responders during that period (measured as DTH skin reaction and/or in vitro T-cell response) [349]. T-cell activity, investigated by in vitro T-cell proliferation assay, was still present seven to nine years after vaccination.

- CEA and MUC1: Carcinoembryonic antigen (CEA) glycoprotein is expressed at a low level in normal colonic epithelium but is overexpressed in many malignant diseases, including those of the colon, rectum, stomach and pancreas (85-90\%) [350]. Its serum level 
is sometimes used as a marker for the diagnosis of pancreatic cancer, with a sensitivity of $25-40 \%$ and a specificity of 70-90\% [351-353].

TRICOM is a poxvirus-based vaccine containing tumour-associated antigens in combination with a TRIaid of COstimulatory Molecules (B7-1, Intercellular Adhesion Molecule-1 ICAM-1, Leucocyte Function-Associated Antigen-3 - LFA-3) [354]. The aim is to enhance tumour-specific T-cell response. Marshall et al conducted a phase I study of 58 patients using the replication-defective fowlpox recombinant (rF)-CEA(6D)-TRICOM and recombinant vaccinia (rV)-CEA(6D)-TRICOM vaccines, with or without GM-CSF [355]. CEA(6D) contains a modification of the HLA-A2 CEA CAP-1 epitope to enhance its immunogenicity. Only one patient had pancreatic cancer - she was previously diagnosed, had had radiotherapy with chemosensitisation, followed by ALVAC-CEA (replicationdefective avipox containing the CEA gene) vaccine because of disease progression [356]. She remained stable for six months after ALVAC-CEA but progressed with rising CA 19-9 and pain unresponsive to chemotherapy. After two vaccinations with (rF)-CEA(6D)TRICOM both CA 19-9 and pain decreased for over a year. Enhanced CEA-specific T-cell responses were noted in the majority of patients.

To boost MUC1-specific immune response, a vaccine composed of MUC1 peptide and SBAS2 adjuvant was tested in a phase I study [357]. There was an increase in the percentage of CD8+ T-cells and MUC1-specific antibody (some developed IgG). Hope for the CEA or MUC1 vaccine was nevertheless crushed when a phase III trial of 255 patients using PANVAC-VF (vaccine consisted of recombinant vaccinia and fowlpox viruses coexpressing CEA, MUC-1 and TRICOM) failed to improve overall survival compared to palliative chemotherapy or best supportive care [358].

- Gastrin: G17DT (Gastrimmune or Insegia) is an immunoconjugate of the amino-terminal sequence of gastrin-17 (G-17) linked by means of a spacer peptide to diphtheria toxoid. Given intramuscularly it induces the formation of antibodies that can neutralise both amidated-G-17 and the precursor glycine-extended G17 [359]. In a phase II study of 30 patients, 67\% mounted an antibody response [359]. A significantly higher response (82\%) was achieved in those given the highest dose of $250 \mu \mathrm{g}$ compared to $46 \%$ in the $100 \mu \mathrm{g}$ group. MS was significantly higher (217 days) for the antibody responders compared to nonresponders (121 days; $\mathrm{p}=0.0023$ ). When used as a monotherapy for patients with advanced pancreatic cancer unwilling or unsuitable to take chemotherapy, MS was 151 compared to 82 days in the placebo group ( $\mathrm{p}=0.03$ ) [360]. G17DT was subsequently tested in a phase III trial with or without gemcitabine in 383 untreated patients with locally advanced, recurrent or metastatic pancreatic adenocarcinoma [361]. This unfortunately showed that the addition of G17DT did not improve overall survival or secondary endpoints (e.g. response rate, time to progression). Increasing G-17 antibody titre levels in a subset of patients, however, were associated with increased survival.

- Mesothelin: Thomas and colleagues provided the first direct evidence, by using mesothelin epitopes, that pancreatic cancer-specific CD8+ T-cell response can be generated via cross-presentation by an approach that recruits APCs to the vaccination site [362]. Gaffney et al studied the mesothelin DNA vaccine in combination with the antiglucocorticoid-induced TNF receptor antibody (anti-GITR) in mice with syngeneic mesothelin-expressing pancreatic cancer [363]. 50\% of animals treated with mesothelin were tumour-free 25 days after tumour injection compared to $0 \%$ of non-treated mice. This increased to $94 \%$ with the addition of anti-GITR. The agonist anti-GITR served to enhance T-cell-mediated response of the vaccine [364,365]. 
- Telomerase: The telomerase peptide vaccine GV1001 was tested in a phase I/II study of 48 patients with unresectable pancreatic cancer [366]. They received intradermal injection in combination with GM-CSF. Immune responses, as measured by DTH skin reaction and Tcell proliferation in vitro, were demonstrated in 24 of 38 evaluable patients, with the highest percentage (75\%) in the intermediate dose group. MS for this group was significantly longer at 8.6 months, and one-year survival was $25 \%$. GV1001 was given to patients in a phase I trial using imiquimod as an adjuvant [367]. Imiquimod acts by binding to Toll-like receptor 7 on immune cells, resulting in the production of cytokines such as IFN- $a$, IFN- $\beta$ and IL- 12 . Immune response was found in up to six (46\%) of 13 evaluable patients.

These promising results have led to the commencement of the large, phase III TeloVac trial exploring gemcitabine and capecitabine chemotherapy with concurrent or sequential GV1001 in patients with locally advanced and metastatic pancreatic cancer.

- Survivin: Survivin-specific CTLs were isolated from pancreatic cancer patients and these could lyse pancreatic carcinoma cell lines in vitro [368]. Vaccination with survivin DNA prolonged survival in murine pancreatic and lymphoma tumour models, associated with slower tumour growth and increased lymphocyte infiltration [369]. Survivin peptide was tested in a patient with gemcitabine refractory pancreatic cancer [370]. Whilst on treatment he had complete remission of liver metastases after six months. However when he was weaned from the vaccination he developed recurrent disease. Vaccine-induced immune activity was detected by IFN- $\gamma$ enzyme-linked immunospot (ELISPOT) assay.

Antigen-pulsed DCs-Antigen-specific T-cell responses are initiated by DCs. They capture antigens secreted or shed by tumour cells and present peptides in association with the MHC class I and II molecules. This results in the expression and upregulation of cytokines and costimulatory molecules which in turn stimulate CD4+ and CD8+ T-cells to mount an antitumour response. As such DCs that carry the tumour antigen of interest is an ideal adjuvant in cancer immunotherapy.

- TNP-470: As described previously, TNP-470 is an antiangiogenic inhibitor. Miyazaki and colleagues tested the combination of DC immunotherapy and TNP-470 in a syngeneic, orthotopic murine pancreatic cancer model [371]. DCs were coincubated with tumour lysates of the murine pancreatic adenocarcinoma cell line Panc02. C57BL/6 mice treated with these DCs showed significant reduction in tumour volume and mean vascular density, associated with prolonged survival. Combination therapy was better than either one alone. Infiltration of CD4+ and CD8+ cells were significantly higher in those treated with tumour lysate-pulsed DCs compared to non-pulsed DCs.

- CEA: In one study, three patients with resected pancreatic cancer following neoadjuvant chemoradiotherapy were given monthly injections of autologous, monocyte-derived DCs loaded with the mRNA of CEA for six months [372]. No toxicities were reported and all patients remained disease-free for more than 30 months from diagnosis.

- MUC1: In a phase I/II trial, human autologous DCs transfected with MUC1 cDNA were used as a vaccine for ten patients with advanced breast, pancreatic or papillary cancer [373]. Four patients showed a two- to ten-fold increase in the frequency of mucin-specific IFN- $\gamma$ secreting CD8+ T-cells, suggesting an immune response. In a phase $1 \mathrm{~b}$ study, eight patients with pancreatic or biliary tumours were vaccinated with DCs pulsed with MUC1 [374]. Of the seven serum samples obtained, two showed isotype switching of anti-MUC1 antibodies from IgM to IgG. 


\section{Conclusion}

Pancreatic cancer is a devastating disease that has a high morbidity and mortality. Early diagnosis and treatment, although difficult to achieve, still offers the best chance of survival. Patients with advanced and metastatic diseases have to rely on palliative treatments that are unpleasant and have limited therapeutic effects. Over the past decades our understanding of this condition has increased tremendously and numerous molecular level-targeted biological therapies have been studied. So far not many have made it to the clinical setting and for those which did, results were far from curative and treatments have to be delivered with standard chemo- or radio-therapy for maximum benefits. Nonetheless multimodality treatments are still the way forward given the complexity but often non-specific nature of tumour compared to normal cells. As such this is still a significant area for extensive research and considerable resources will continue to be channelled into the development of novel biological treatment agents. The results of a number of clinical trials are eagerly awaited (Table 3).

\section{References}

1. Sultana A, Smith C Tudur, Cunningham D, Starling N, Tait D, Neoptolemos JP, Ghaneh P. Systematic review, including metaanalyses, on the management of locally advanced pancreatic cancer using radiation/combined modality therapy. Br J Cancer. 2007; 96:1183-1190. [PubMed: 17406358]

2. Jemal A, Siegel R, Ward E, Murray T, Xu J, Thun MJ. Cancer statistics, 2007. CA Cancer J Clin. 2007; 57:43-66. [PubMed: 17237035]

3. Guidelines for the management of patients with pancreatic cancer periampullary and ampullary carcinomas. Gut. 2005; 54(Suppl 5):v1-16. [PubMed: 15888770]

4. Burris HA 3rd, Moore MJ, Andersen J, Green MR, Rothenberg ML, Modiano MR, Cripps MC, Portenoy RK, Storniolo AM, Tarassoff P, Nelson R, Dorr FA, Stephens CD, Von Hoff DD. Improvements in survival and clinical benefit with gemcitabine as first-line therapy for patients with advanced pancreas cancer: a randomized trial. J Clin Oncol. 1997; 15:2403-2413. [PubMed: 9196156]

5. Sultana A, Smith CT, Cunningham D, Starling N, Neoptolemos JP, Ghaneh P. Meta-analyses of chemotherapy for locally advanced and metastatic pancreatic cancer. J Clin Oncol. 2007; 25:26072615. [PubMed: 17577041]

6. Ghaneh P, Costello E, Neoptolemos JP. Biology and management of pancreatic cancer. Gut. 2007; 56:1134-1152. [PubMed: 17625148]

7. Almoguera C, Shibata D, Forrester K, Martin J, Arnheim N, Perucho M. Most human carcinomas of the exocrine pancreas contain mutant c-K-ras genes. Cell. 1988; 53:549-554. [PubMed: 2453289]

8. Malumbres M, Barbacid M. RAS oncogenes: the first 30 years. Nat Rev Cancer. 2003; 3:459-465. [PubMed: 12778136]

9. Motojima K, Urano T, Nagata Y, Shiku H, Tsunoda T, Kanematsu T. Mutations in the Kirsten-ras oncogene are common but lack correlation with prognosis and tumor stage in human pancreatic carcinoma. Am J Gastroenterol. 1991; 86:1784-1788. [PubMed: 1962623]

10. Luttges J, Schlehe B, Menke MA, Vogel I, Henne-Bruns D, Kloppel G. The K-ras mutation pattern in pancreatic ductal adenocarcinoma usually is identical to that in associated normal, hyperplastic, and metaplastic ductal epithelium. Cancer. 1999; 85:1703-1710. [PubMed: 10223563]

11. Seufferlein T, Van Lint J, Liptay S, Adler G, Schmid RM. Transforming growth factor alpha activates Ha-Ras in human pancreatic cancer cells with Ki-ras mutations. Gastroenterology. 1999; 116:1441-1452. [PubMed: 10348828]

12. Yoshida T, Ohnami S, Aoki K. Development of gene therapy to target pancreatic cancer. Cancer Sci. 2004; 95:283-289. [PubMed: 15072584]

13. Shichinohe T, Senmaru N, Furuuchi K, Ogiso Y, Ishikura H, Yoshiki T, Takahashi T, Kato H, Kuzumaki N. Suppression of pancreatic cancer by the dominant negative ras mutant, N116Y. J Surg Res. 1996; 66:125-130. [PubMed: 9024823] 
14. Takeuchi M, Shichinohe T, Senmaru N, Miyamoto M, Fujita H, Takimoto M, Kondo S, Katoh H, Kuzumaki N. The dominant negative H-ras mutant, N116Y, suppresses growth of metastatic human pancreatic cancer cells in the liver of nude mice. Gene Ther. 2000; 7:518-526. [PubMed: 10757026]

15. Clanton DJ, Hattori S, Shih TY. Mutations of the ras gene product p21 that abolish guanine nucleotide binding. Proc Natl Acad Sci U S A. 1986; 83:5076-5080. [PubMed: 3014531]

16. Alberts SR, Schroeder M, Erlichman C, Steen PD, Foster NR, Moore DF Jr. Rowland KM Jr. Nair S, Tschetter LK, Fitch TR. Gemcitabine and ISIS-2503 for patients with locally advanced or metastatic pancreatic adenocarcinoma: a North Central Cancer Treatment Group phase II trial. J Clin Oncol. 2004; 22:4944-4950. [PubMed: 15611509]

17. Hannon GJ, Rossi JJ. Unlocking the potential of the human genome with RNA interference. Nature. 2004; 431:371-378. [PubMed: 15372045]

18. Fleming JB, Shen GL, Holloway SE, Davis M, Brekken RA. Molecular consequences of silencing mutant K-ras in pancreatic cancer cells: justification for K-ras-directed therapy. Mol Cancer Res. 2005; 3:413-423. [PubMed: 16046552]

19. Brummelkamp TR, Bernards R, Agami R. Stable suppression of tumorigenicity by virus-mediated RNA interference. Cancer Cell. 2002; 2:243-247. [PubMed: 12242156]

20. Van Cutsem E, van de Velde H, Karasek P, Oettle H, Vervenne WL, Szawlowski A, Schoffski P, Post S, Verslype C, Neumann H, Safran H, Humblet Y, Ruixo J Perez, Ma Y, Von Hoff D. Phase III trial of gemcitabine plus tipifarnib compared with gemcitabine plus placebo in advanced pancreatic cancer. J Clin Oncol. 2004; 22:1430-1438. [PubMed: 15084616]

21. Downward J. Targeting RAS signalling pathways in cancer therapy. Nat Rev Cancer. 2003; 3:1122. [PubMed: 12509763]

22. Brunner TB, Cengel KA, Hahn SM, Wu J, Fraker DL, McKenna WG, Bernhard EJ. Pancreatic cancer cell radiation survival and prenyltransferase inhibition: the role of K-Ras. Cancer Res. 2005; 65:8433-8441. [PubMed: 16166322]

23. Cengel KA, Voong KR, Chandrasekaran S, Maggiorella L, Brunner TB, Stanbridge E, Kao GD, McKenna WG, Bernhard EJ. Oncogenic K-Ras signals through epidermal growth factor receptor and wild-type H-Ras to promote radiation survival in pancreatic and colorectal carcinoma cells. Neoplasia. 2007; 9:341-348. [PubMed: 17460778]

24. Lobell RB, Omer CA, Abrams MT, Bhimnathwala HG, Brucker MJ, Buser CA, Davide JP, deSolms SJ, Dinsmore CJ, Ellis-Hutchings MS, Kral AM, Liu D, Lumma WC, Machotka SV, Rands E, Williams TM, Graham SL, Hartman GD, Oliff AI, Heimbrook DC, Kohl NE. Evaluation of farnesyl:protein transferase and geranylgeranyl:protein transferase inhibitor combinations in preclinical models. Cancer Res. 2001; 61:8758-8768. [PubMed: 11751396]

25. Martin NE, Brunner TB, Kiel KD, DeLaney TF, Regine WF, Mohiuddin M, Rosato EF, Haller DG, Stevenson JP, Smith D, Pramanik B, Tepper J, Tanaka WK, Morrison B, Deutsch P, Gupta AK, Muschel RJ, McKenna WG, Bernhard EJ, Hahn SM. A phase I trial of the dual farnesyltransferase and geranylgeranyltransferase inhibitor L-778,123 and radiotherapy for locally advanced pancreatic cancer. Clin Cancer Res. 2004; 10:5447-5454. [PubMed: 15328183]

26. Marshall J. Clinical implications of the mechanism of epidermal growth factor receptor inhibitors. Cancer. 2006; 107:1207-1218. [PubMed: 16909423]

27. Baselga J, Arteaga CL. Critical update and emerging trends in epidermal growth factor receptor targeting in cancer. J Clin Oncol. 2005; 23:2445-2459. [PubMed: 15753456]

28. Lee J, Jang KT, Ki CS, Lim T, Park YS, Lim HY, Choi DW, Kang WK, Park K, Park JO. Impact of epidermal growth factor receptor (EGFR) kinase mutations, EGFR gene amplifications, and KRAS mutations on survival of pancreatic adenocarcinoma. Cancer. 2007; 109:1561-1569. [PubMed: 17354229]

29. Lemoine NR, Hughes CM, Barton CM, Poulsom R, Jeffery RE, Kloppel G, Hall PA, Gullick WJ. The epidermal growth factor receptor in human pancreatic cancer. J Pathol. 1992; 166:7-12. [PubMed: 1538276]

30. Korc M, Chandrasekar B, Yamanaka Y, Friess H, Buchier M, Beger HG. Overexpression of the epidermal growth factor receptor in human pancreatic cancer is associated with concomitant 
increases in the levels of epidermal growth factor and transforming growth factor alpha. J Clin Invest. 1992; 90:1352-1360. [PubMed: 1401070]

31. Bloomston M, Bhardwaj A, Ellison EC, Frankel WL. Epidermal growth factor receptor expression in pancreatic carcinoma using tissue microarray technique. Dig Surg. 2006; 23:74-79. [PubMed: 16717472]

32. Yamanaka Y, Friess H, Kobrin MS, Buchler M, Beger HG, Korc M. Coexpression of epidermal growth factor receptor and ligands in human pancreatic cancer is associated with enhanced tumor aggressiveness. Anticancer Res. 1993; 13:565-569. [PubMed: 8317885]

33. Buck E, Eyzaguirre A, Haley JD, Gibson NW, Cagnoni P, Iwata KK. Inactivation of Akt by the epidermal growth factor receptor inhibitor erlotinib is mediated by HER-3 in pancreatic and colorectal tumor cell lines and contributes to erlotinib sensitivity. Mol Cancer Ther. 2006; 5:20512059. [PubMed: 16928826]

34. Frolov A, Schuller K, Tzeng CW, Cannon EE, Ku BC, Howard JH, Vickers SM, Heslin MJ, Buchsbaum DJ, Arnoletti JP. ErbB3 Expression and Dimerization with EGFR Influence Pancreatic Cancer Cell Sensitivity to Erlotinib. Cancer Biol Ther. 2007; 6

35. Bruns CJ, Solorzano CC, Harbison MT, Ozawa S, Tsan R, Fan D, Abbruzzese J, Traxler P, Buchdunger E, Radinsky R, Fidler IJ. Blockade of the epidermal growth factor receptor signaling by a novel tyrosine kinase inhibitor leads to apoptosis of endothelial cells and therapy of human pancreatic carcinoma. Cancer Res. 2000; 60:2926-2935. [PubMed: 10850439]

36. Moore MJ, Goldstein D, Hamm J, Figer A, Hecht JR, Gallinger S, Au HJ, Murawa P, Walde D, Wolff RA, Campos D, Lim R, Ding K, Clark G, Voskoglou-Nomikos T, Ptasynski M, Parulekar W. Erlotinib plus gemcitabine compared with gemcitabine alone in patients with advanced pancreatic cancer: a phase III trial of the National Cancer Institute of Canada Clinical Trials Group. J Clin Oncol. 2007; 25:1960-1966. [PubMed: 17452677]

37. Kulke MH, Blaszkowsky LS, Ryan DP, Clark JW, Meyerhardt JA, Zhu AX, Enzinger PC, Kwak EL, Muzikansky A, Lawrence C, Fuchs CS. Capecitabine Plus Erlotinib in GemcitabineRefractory Advanced Pancreatic Cancer. J Clin Oncol. 2007; 25:4787-4792. [PubMed: 17947726]

38. Li J, Kleeff J, Giese N, Buchler MW, Korc M, Friess H. Gefitinib ('Iressa', ZD1839), a selective epidermal growth factor receptor tyrosine kinase inhibitor, inhibits pancreatic cancer cell growth, invasion, and colony formation. Int J Oncol. 2004; 25:203-210. [PubMed: 15202007]

39. Pino MS, Shrader M, Baker CH, Cognetti F, Xiong HQ, Abbruzzese JL, McConkey DJ. Transforming growth factor alpha expression drives constitutive epidermal growth factor receptor pathway activation and sensitivity to gefitinib (Iressa) in human pancreatic cancer cell lines. Cancer Res. 2006; 66:3802-3812. [PubMed: 16585207]

40. Fountzilas G, Murray S, Xiros N, Karayannopoulou G, Dafni U, Linardou H, Kalogera-Fountzila A, Bobos M, Koumarianou A, Kosmidis P. Gemcitabine (G) combined with gefitinib in patients with inoperable or metastatic pancreatic cancer. A phase II trial. J Clin Oncol (Meeting Abstracts). 2007; 25:15016.

41. Ignatiadis M, Polyzos A, Stathopoulos GP, Tselepatiotis E, Christophylakis C, Kalbakis K, Vamvakas L, Kotsakis A, Potamianou A, Georgoulias V. A multicenter phase II study of docetaxel in combination with gefitinib in gemcitabine-pretreated patients with advanced/ metastatic pancreatic cancer. Oncology. 2006; 71:159-163. [PubMed: 17646699]

42. Blaszkowsky LS, Ryan DP, Earle C, Kwak E, Fuchs C, Meyerhardt JA, Stuart K, Zhu AX, Enzinger P, Kulke MH. A phase II study of docetaxel in combination with ZD1839 (gefitinib) in previously treated patients with metastatic pancreatic cancer. J Clin Oncol (Meeting Abstracts). 2007; 25:15080.

43. Kulke MH, Blaszkowsky LS, Ryan DP, Clark JW, Meyerhardt JA, Zhu AX, Enzinger PC, Kwak EL, Muzikansky A, Lawrence C, Fuchs CS. Capecitabine plus erlotinib in gemcitabine-refractory advanced pancreatic cancer. J Clin Oncol. 2007; 25:4787-4792. [PubMed: 17947726]

44. Midgley R, Flaherty KT, Haller DG, Versola MJ, Smith DA, Koch KM, Pandite L, Kerr DJ, O'Dwyer PJ, Middleton MR. Phase I study of GW572016 (lapatinib), a dual kinase inhibitor, in combination with irinotecan (IR), 5-fluorouracil (FU) and leucovorin (LV). J Clin Oncol (Meeting Abstracts). 2005; 23:3086. 
45. Safran H, Iannitti D, Miner T, Demel K, Yoo D, Joseph P, Maia-Acuna C, Lockridge L, Evans D, Teresa K. GW572016, gemcitabine and GW572016, gemcitabine, oxaliplatin, a two-stage, phase I study for advanced pancreaticobiliary cancer. J Clin Oncol (Meeting Abstracts). 2006; 24:4002.

46. Yeh TC, Marsh V, Bernat BA, Ballard J, Colwell H, Evans RJ, Parry J, Smith D, Brandhuber BJ, Gross S, Marlow A, Hurley B, Lyssikatos J, Lee PA, Winkler JD, Koch K, Wallace E. Biological characterization of ARRY-142886 (AZD6244), a potent, highly selective mitogen-activated protein kinase kinase 1/2 inhibitor. Clin Cancer Res. 2007; 13:1576-1583. [PubMed: 17332304]

47. Rinehart J, Adjei AA, Lorusso PM, Waterhouse D, Hecht JR, Natale RB, Hamid O, Varterasian M, Asbury P, Kaldjian EP, Gulyas S, Mitchell DY, Herrera R, Sebolt-Leopold JS, Meyer MB. Multicenter phase II study of the oral MEK inhibitor, CI-1040, in patients with advanced nonsmall-cell lung, breast, colon, and pancreatic cancer. J Clin Oncol. 2004; 22:4456-4462. [PubMed: 15483017]

48. Semba S, Moriya T, Kimura W, Yamakawa M. Phosphorylated Akt/PKB controls cell growth and apoptosis in intraductal papillary-mucinous tumor and invasive ductal adenocarcinoma of the pancreas. Pancreas. 2003; 26:250-257. [PubMed: 12657951]

49. Takeda A, Osaki M, Adachi K, Honjo S, Ito H. Role of the phosphatidylinositol 3' -kinase-Akt signal pathway in the proliferation of human pancreatic ductal carcinoma cell lines. Pancreas. 2004; 28:353-358. [PubMed: 15084985]

50. Hennessy BT, Smith DL, Ram PT, Lu Y, Mills GB. Exploiting the PI3K/AKT pathway for cancer drug discovery. Nat Rev Drug Discov. 2005; 4:988-1004. [PubMed: 16341064]

51. Ruggeri BA, Huang L, Wood M, Cheng JQ, Testa JR. Amplification and overexpression of the AKT2 oncogene in a subset of human pancreatic ductal adenocarcinomas. Mol Carcinog. 1998; 21:81-86. [PubMed: 9496907]

52. Cheng JQ, Ruggeri B, Klein WM, Sonoda G, Altomare DA, Watson DK, Testa JR. Amplification of AKT2 in human pancreatic cells and inhibition of AKT2 expression and tumorigenicity by antisense RNA. Proc Natl Acad Sci U S A. 1996; 93:3636-3641. [PubMed: 8622988]

53. Wullschleger S, Loewith R, Hall MN. TOR signaling in growth and metabolism. Cell. 2006; 124:471-484. [PubMed: 16469695]

54. Escarcega RO, Fuentes-Alexandro S, Garcia-Carrasco M, Gatica A, Zamora A. The transcription factor nuclear factor-kappa B and cancer. Clin Oncol (R Coll Radiol). 2007; 19:154-161. [PubMed: 17355113]

55. Bharti AC, Aggarwal BB. Nuclear factor-kappa B and cancer: its role in prevention and therapy. Biochem Pharmacol. 2002; 64:883-888. [PubMed: 12213582]

56. Bondar VM, Sweeney-Gotsch B, Andreeff M, Mills GB, McConkey DJ. Inhibition of the phosphatidylinositol 3'-kinase-AKT pathway induces apoptosis in pancreatic carcinoma cells in vitro and in vivo. Mol Cancer Ther. 2002; 1:989-997. [PubMed: 12481421]

57. Ng SS, Tsao MS, Nicklee T, Hedley DW. Wortmannin inhibits pkb/akt phosphorylation and promotes gemcitabine antitumor activity in orthotopic human pancreatic cancer xenografts in immunodeficient mice. Clin Cancer Res. 2001; 7:3269-3275. [PubMed: 11595724]

58. Stoll V, Calleja V, Vassaux G, Downward J, Lemoine NR. Dominant negative inhibitors of signalling through the phosphoinositol 3-kinase pathway for gene therapy of pancreatic cancer. Gut. 2005; 54:109-116. [PubMed: 15591514]

59. Ito D, Fujimoto K, Mori T, Kami K, Koizumi M, Toyoda E, Kawaguchi Y, Doi R. In vivo antitumor effect of the mTOR inhibitor CCI-779 and gemcitabine in xenograft models of human pancreatic cancer. Int J Cancer. 2006; 118:2337-2343. [PubMed: 16331623]

60. Maute L, Glienke W, Milz E, Bauer N, Bergmann L. Treatment with rAD001 improves the efficacy of siRNA mediated down-regulation of survivin/BIRC5 in pancreatic carcinoma cell lines. J Clin Oncol (Meeting Abstracts). 2007; 25:15146.

61. Wang Y, Zhao Q, Ma S, Yang F, Gong Y, Ke C. Sirolimus Inhibits Human Pancreatic Carcinoma Cell Proliferation by a Mechanism Linked to the Targeting of mTOR/HIF-1 Alpha/VEGF Signaling. IUBMB Life. 2007; 59:717-721. [PubMed: 17968710]

62. Rajkumar SV, Richardson PG, Hideshima T, Anderson KC. Proteasome Inhibition As a Novel Therapeutic Target in Human Cancer. J Clin Oncol. 2005; 23:630-639. [PubMed: 15659509] 
63. Yeung BH, Huang DC, Sinicrope FA. PS-341 (bortezomib) induces lysosomal cathepsin B release and a caspase-2-dependent mitochondrial permeabilization and apoptosis in human pancreatic cancer cells. J Biol Chem. 2006; 281:11923-11932. [PubMed: 16446371]

64. Nawrocki ST, Carew JS, Pino MS, Highshaw RA, Dunner K Jr. Huang P, Abbruzzese JL, McConkey DJ. Bortezomib sensitizes pancreatic cancer cells to endoplasmic reticulum stressmediated apoptosis. Cancer Res. 2005; 65:11658-11666. [PubMed: 16357177]

65. Bold RJ, Virudachalam S, McConkey DJ. Chemosensitization of pancreatic cancer by inhibition of the 26S proteasome. J Surg Res. 2001; 100:11-17. [PubMed: 11516199]

66. Fahy BN, Schlieman MG, Virudachalam S, Bold RJ. Schedule-dependent molecular effects of the proteasome inhibitor bortezomib and gemcitabine in pancreatic cancer. J Surg Res. 2003; 113:8895. [PubMed: 12943815]

67. Nawrocki ST, Sweeney-Gotsch B, Takamori R, McConkey DJ. The proteasome inhibitor bortezomib enhances the activity of docetaxel in orthotopic human pancreatic tumor xenografts. Mol Cancer Ther. 2004; 3:59-70. [PubMed: 14749476]

68. Shah SA, Potter MW, McDade TP, Ricciardi R, Perugini RA, Elliott PJ, Adams J, Callery MP. 26S proteasome inhibition induces apoptosis and limits growth of human pancreatic cancer. J Cell Biochem. 2001; 82:110-122. [PubMed: 11400168]

69. Miyamoto Y, Hosotani R, Wada M, Lee JU, Koshiba T, Fujimoto K, Tsuji S, Nakajima S, Doi R, Kato M, Shimada Y, Imamura M. Immunohistochemical analysis of Bcl-2, Bax, Bcl-X, and Mcl-1 expression in pancreatic cancers. Oncology. 1999; 56:73-82. [PubMed: 9885381]

70. Yeung B, Freeburg EN, Huang DCT, Sinicrope FA. Bortezomib induces oxidative stress and apoptosis that are synergistically enhanced by a Bcl-2 inhibitor in human pancreatic cancer cells. $\mathrm{J}$ Clin Oncol (Meeting Abstracts). 2005; 23:3161.

71. Ryan DP, O’Neil BH, Supko JG, Lima CM Rocha, Dees EC, Appleman LJ, Clark J, Fidias P, Orlowski RZ, Kashala O, Eder JP, Cusack JC Jr. A Phase I study of bortezomib plus irinotecan in patients with advanced solid tumors. Cancer. 2006; 107:2688-2697. [PubMed: 17075878]

72. Shapiro CL, Ramaswamy B, Young D, Lamb T, Lucas D, Shaaf L, Sahenk Z, Collamore M, Byrd J, Wright J, Grever M. Phase I trial of bortezomib in combination with paclitaxel in advanced solid tumor patients (pts). J Clin Oncol (Meeting Abstracts). 2005; 23:3104.

73. Iqbal S, Cole S, Yang D, Lara PN, Gumerlock PH, Shibata S, Synold T, Doroshow JH, Gandara D, Lenz HJ. Phase I study of PS-341 (bortezomib) with 5-fluorouracil/leucovorin (5-FU/LV) in advanced solid tumors: A California Cancer Consortium study. J Clin Oncol (Meeting Abstracts). 2004; $22: 2057$.

74. Cusack JC Jr. Liu R, Xia L, Ljungman D, Bahjat R, Palladino MA Jr. Oral proteasome inhibitor (NPI-0052) enhances sensitivity to combination Gemcitabine and Erbitux in a pancreatic cancer xenograft model. AACR Meeting Abstracts. 2005; 2005:1167-a.

75. Li Y, Ellis KL, Ali S, El-Rayes BF, Nedeljkovic-Kurepa A, Kucuk O, Philip PA, Sarkar FH. Apoptosis-inducing effect of chemotherapeutic agents is potentiated by soy isoflavone genistein, a natural inhibitor of NF-kappaB in BxPC-3 pancreatic cancer cell line. Pancreas. 2004; 28:e90-95. [PubMed: 15097869]

76. Li Y, Ahmed F, Ali S, Philip PA, Kucuk O, Sarkar FH. Inactivation of nuclear factor kappaB by soy isoflavone genistein contributes to increased apoptosis induced by chemotherapeutic agents in human cancer cells. Cancer Res. 2005; 65:6934-6942. [PubMed: 16061678]

77. Buchler P, Reber HA, Buchler MW, Friess H, Lavey RS, Hines OJ. Antiangiogenic activity of genistein in pancreatic carcinoma cells is mediated by the inhibition of hypoxia-inducible factor-1 and the down-regulation of VEGF gene expression. Cancer. 2004; 100:201-210. [PubMed: 14692041]

78. Buchler P, Gukovskaya AS, Mouria M, Buchler MC, Buchler MW, Friess H, Pandol SJ, Reber HA, Hines OJ. Prevention of metastatic pancreatic cancer growth in vivo by induction of apoptosis with genistein, a naturally occurring isoflavonoid. Pancreas. 2003; 26:264-273. [PubMed: 12657953]

79. Wang Z, Zhang Y, Banerjee S, Li Y, Sarkar FH. Inhibition of nuclear factor kappab activity by genistein is mediated via Notch-1 signaling pathway in pancreatic cancer cells. Int J Cancer. 2006; 118:1930-1936. [PubMed: 16284950] 
80. Banerjee S, Zhang Y, Ali S, Bhuiyan M, Wang Z, Chiao PJ, Philip PA, Abbruzzese J, Sarkar FH. Molecular evidence for increased antitumor activity of gemcitabine by genistein in vitro and in vivo using an orthotopic model of pancreatic cancer. Cancer Res. 2005; 65:9064-9072. [PubMed: 16204081]

81. Mohammad RM, Banerjee S, Li Y, Aboukameel A, Kucuk O, Sarkar FH. Cisplatin-induced antitumor activity is potentiated by the soy isoflavone genistein in BxPC-3 pancreatic tumor xenografts. Cancer. 2006; 106:1260-1268. [PubMed: 16475211]

82. Banerjee S, Zhang Y, Wang Z, Che M, Chiao PJ, Abbruzzese JL, Sarkar FH. In vitro and in vivo molecular evidence of genistein action in augmenting the efficacy of cisplatin in pancreatic cancer. Int J Cancer. 2007; 120:906-917. [PubMed: 17131310]

83. El-Rayes BF, Ali S, Ali IF, Philip PA, Abbruzzese J, Sarkar FH. Potentiation of the effect of erlotinib by genistein in pancreatic cancer: the role of Akt and nuclear factor-kappaB. Cancer Res. 2006; 66:10553-10559. [PubMed: 17079479]

84. Ellis KL, Mohammad R, Wang S, Wu X, Chen J, Min J, Sarkar FH. Potentiation of apoptosis inducing activity of BL-193, an inhibitor of Bcl-XL protein, by genistein in pancreatic cancer cells. J Clin Oncol (Meeting Abstracts). 2004; 22:3133.

85. Kunnumakkara AB, Guha S, Krishnan S, Diagaradjane P, Gelovani J, Aggarwal BB. Curcumin potentiates antitumor activity of gemcitabine in an orthotopic model of pancreatic cancer through suppression of proliferation, angiogenesis, and inhibition of nuclear factor-kappaB-regulated gene products. Cancer Res. 2007; 67:3853-3861. [PubMed: 17440100]

86. Glienke W, Maute L, Milz E, Bauer N, Bergmann L. Curcumin inhibits constitutive STAT3 phosphorylation in human pancreatic cancer cell lines and down-regulates survivin/BIRC5 gene expression. J Clin Oncol (Meeting Abstracts). 2007; 25:15030.

87. Hidaka H, Ishiko T, Furuhashi T, Kamohara H, Suzuki S, Miyazaki M, Ikeda O, Mita S, Setoguchi T, Ogawa M. Curcumin inhibits interleukin 8 production and enhances interleukin 8 receptor expression on the cell surface:impact on human pancreatic carcinoma cell growth by autocrine regulation. Cancer. 2002; 95:1206-1214. [PubMed: 12216086]

88. Li L, Aggarwal BB, Shishodia S, Abbruzzese J, Kurzrock R. Nuclear factor-kappaB and IkappaB kinase are constitutively active in human pancreatic cells, and their down-regulation by curcumin (diferuloylmethane) is associated with the suppression of proliferation and the induction of apoptosis. Cancer. 2004; 101:2351-2362. [PubMed: 15476283]

89. Lev-Ari S, Vexler A, Starr A, Ashkenazy-Voghera M, Greif J, Aderka D, Ben-Yosef R. Curcumin augments gemcitabine cytotoxic effect on pancreatic adenocarcinoma cell lines. Cancer Invest. 2007; 25:411-418. [PubMed: 17882652]

90. Thoutreddy S, Ali S, Mohammad R, Sarkar FH. Sensitization of pancreatic cancer cells to ApoG2 induced killing by curcumin. J Clin Oncol (Meeting Abstracts). 2006; 24:13152.

91. Dhillon N, Aggarwal BB, Newman RA, Wolff RA, Kunnumakkara AB, Abbruzzese JL, Hong DS, Camacho LH, Ng C, Kurzrock R. Curcumin and pancreatic cancer: Phase II clinical trial experience. J Clin Oncol (Meeting Abstracts). 2007; 25:4599.

92. Ding XZ, Hennig R, Adrian TE. Lipoxygenase and cyclooxygenase metabolism: new insights in treatment and chemoprevention of pancreatic cancer. Mol Cancer. 2003; 2:10. [PubMed: 12575899]

93. Molina MA, Sitja-Arnau M, Lemoine MG, Frazier ML, Sinicrope FA. Increased Cyclooxygenase-2 Expression in Human Pancreatic Carcinomas and Cell Lines: Growth Inhibition by Nonsteroidal Anti-Inflammatory Drugs. Cancer Res. 1999; 59:4356-4362. [PubMed: 10485483]

94. Tucker ON, Dannenberg AJ, Yang EK, Zhang F, Teng L, Daly JM, Soslow RA, Masferrer JL, Woerner BM, Koki AT, Fahey TJ III. Cyclooxygenase-2 Expression Is Up-Regulated in Human Pancreatic Cancer. Cancer Res. 1999; 59:987-990. [PubMed: 10070951]

95. Okami J, Yamamoto H, Fujiwara Y, Tsujie M, Kondo M, Noura S, Oshima S, Nagano H, Dono K, Umeshita K, Ishikawa O, Sakon M, Matsuura N, Nakamori S, Monden M. Overexpression of Cyclooxygenase-2 in Carcinoma of the Pancreas. Clin Cancer Res. 1999; 5:2018-2024. [PubMed: 10473081] 
96. Yip-Schneider MT, Barnard DS, Billings SD, Cheng L, Heilman DK, Lin A, Marshall SJ, Crowell PL, Marshall MS, Sweeney CJ. Cyclooxygenase-2 expression in human pancreatic adenocarcinomas. Carcinogenesis. 2000; 21:139-146. [PubMed: 10657949]

97. Anderson KE, Johnson TW, Lazovich D, Folsom AR. Association Between Nonsteroidal AntiInflammatory Drug Use and the Incidence of Pancreatic Cancer. J. Natl. Cancer Inst. 2002; 94:1168-1171. [PubMed: 12165642]

98. Ding XZ, Tong WG, Adrian TE. Blockade of cyclooxygenase-2 inhibits proliferation and induces apoptosis in human pancreatic cancer cells. Anticancer Res. 2000; 20:2625-2631. [PubMed: 10953335]

99. Yip-Schneider MT, Sweeney CJ, Jung SH, Crowell PL, Marshall MS. Cell cycle effects of nonsteroidal anti-inflammatory drugs and enhanced growth inhibition in combination with gemcitabine in pancreatic carcinoma cells. J Pharmacol Exp Ther. 2001; 298:976-985. [PubMed: 11504793]

100. El-Rayes BF, Ali S, Sarkar FH, Philip PA. Cyclooxygenase-2-dependent and -independent effects of celecoxib in pancreatic cancer cell lines. Mol Cancer Ther. 2004; 3:1421-1426. [PubMed: 15542781]

101. Raut CP, Nawrocki S, Lashinger LM, Davis DW, Khanbolooki S, Xiong H, Ellis LM, McConkey DJ. Celecoxib inhibits angiogenesis by inducing endothelial cell apoptosis in human pancreatic tumor xenografts. Cancer Biol Ther. 2004; 3:1217-1224. [PubMed: 15477758]

102. Wei D, Wang L, He Y, Xiong HQ, Abbruzzese JL, Xie K. Celecoxib inhibits vascular endothelial growth factor expression in and reduces angiogenesis and metastasis of human pancreatic cancer via suppression of Sp1 transcription factor activity. Cancer Res. 2004; 64:2030-2038. [PubMed: 15026340]

103. Xiong HQ, Hess KR, Kayaleh OR, Goodwin JW, Banerjee T, Sinclair SS, Fisch MJ, Wolff RA, Abbruzzese JL. A phase II trial of gemcitabine and celecoxib for metastatic pancreatic cancer. J Clin Oncol (Meeting Abstracts). 2005; 23:4174.

104. Ferrari V, Valcamonico F, Amoroso V, Simoncini E, Vassalli L, Marpicati P, Rangoni G, Grisanti S, Tiberio GA, Nodari F, Strina C, Marini G. Gemcitabine plus celecoxib (GECO) in advanced pancreatic cancer: a phase II trial. Cancer Chemother Pharmacol. 2006; 57:185-190. [PubMed: 16151811]

105. Kerr S, Campbell C, Legore K, Witters L, Harvey H, Lipton A. Phase II trial of gemcitabine and irinotecan plus celecoxib in advanced adenocarcinoma of the pancreas. J Clin Oncol (Meeting Abstracts). 2005; 23:4155.

106. El-Rayes BF, Zalupski MM, Shields AF, Ferris AM, Vaishampayan U, Heilbrun LK, Venkatramanamoorthy R, Adsay V, Philip PA. A phase II study of celecoxib, gemcitabine, and cisplatin in advanced pancreatic cancer. Invest New Drugs. 2005; 23:583-590. [PubMed: 16034525]

107. Milella M, Gelibter A, Di Cosimo S, Bria E, Ruggeri EM, Carlini P, Malaguti P, Pellicciotta M, Terzoli E, Cognetti F. Exploratory phase II study of celecoxib and infusional fluorouracil as second-line treatment for advanced pancreatic (PDAC) and biliary tree cancer (BTC). J Clin Oncol (Meeting Abstracts). 2004; 22:4183.

108. Gelibter A, Milella M, Malaguti P, De Marco S, Ruggeri E, Carlini P, Pino M, Nuzzo C, Sternberg CN, Cognetti F. Pilot study of capecitabine combined with celecoxib (CapCel) as second-line treatment for advanced pancreatic (P) and biliary tree (BT) cancer. J Clin Oncol (Meeting Abstracts). 2006; 24:14055.

109. Lev-Ari S, Zinger H, Kazanov D, Yona D, Ben-Yosef R, Starr A, Figer A, Arber N. Curcumin synergistically potentiates the growth inhibitory and pro-apoptotic effects of celecoxib in pancreatic adenocarcinoma cells. Biomed Pharmacother. 2005; 59(Suppl 2):S276-280. [PubMed: 16507392]

110. Rozengurt E, Walsh JH. Gastrin, CCK, signaling, and cancer. Annu Rev Physiol. 2001; 63:49-76. [PubMed: 11181948]

111. Smith JP, Shih A, Wu Y, McLaughlin PJ, Zagon IS. Gastrin regulates growth of human pancreatic cancer in a tonic and autocrine fashion. Am J Physiol. 1996; 270:R1078-1084. [PubMed: 8928909] 
112. Caplin M, Savage K, Khan K, Brett B, Rode J, Varro A, Dhillon A. Expression and processing of gastrin in pancreatic adenocarcinoma. Br J Surg. 2000; 87:1035-1040. [PubMed: 10931047]

113. Smith JP, Stanley WB, Verderame MF, Zagon IS. The functional significance of the cholecystokinin-C (CCK-C) receptor in human pancreatic cancer. Pancreas. 2004; 29:271-277. [PubMed: 15502642]

114. Chau I, Cunningham D, Russell C, Norman AR, Kurzawinski T, Harper P, Harrison P, Middleton G, Daniels F, Hickish T, Prendeville J, Ross PJ, Theis B, Hull R, Walker M, Shankley N, Kalindjian B, Murray G, Gillbanks A, Black J. Gastrazole (JB95008), a novel CCK2/gastrin receptor antagonist, in the treatment of advanced pancreatic cancer: results from two randomised controlled trials. Br J Cancer. 2006; 94:1107-1115. [PubMed: 16622436]

115. Moschos SJ, Mantzoros CS. The role of the IGF system in cancer: from basic to clinical studies and clinical applications. Oncology. 2002; 63:317-332. [PubMed: 12417786]

116. Peruzzi F, Prisco M, Dews M, Salomoni P, Grassilli E, Romano G, Calabretta B, Baserga R. Multiple signaling pathways of the insulin-like growth factor 1 receptor in protection from apoptosis. Mol Cell Biol. 1999; 19:7203-7215. [PubMed: 10490655]

117. Parrizas M, Saltiel AR, LeRoith D. Insulin-like growth factor 1 inhibits apoptosis using the phosphatidylinositol $3^{\prime}$-kinase and mitogen-activated protein kinase pathways. J Biol Chem. 1997; 272:154-161. [PubMed: 8995241]

118. Zong CS, Chan J, Levy DE, Horvath C, Sadowski HB, Wang LH. Mechanism of STAT3 activation by insulin-like growth factor I receptor. J Biol Chem. 2000; 275:15099-15105. [PubMed: 10747872]

119. Nair PN, De Armond DT, Adamo ML, Strodel WE, Freeman JW. Aberrant expression and activation of insulin-like growth factor-1 receptor (IGF-1R) are mediated by an induction of IGF-1R promoter activity and stabilization of IGF-1R mRNA and contributes to growth factor independence and increased survival of the pancreatic cancer cell line MIA PaCa-2. Oncogene. 2001; 20:8203-8214. [PubMed: 11781836]

120. Hakam A, Fang Q, Karl R, Coppola D. Coexpression of IGF-1R and c-Src proteins in human pancreatic ductal adenocarcinoma. Dig Dis Sci. 2003; 48:1972-1978. [PubMed: 14627343]

121. Adachi Y, Yamamoto H, Imsumran A, Wang Y, Li R, Min Y, Arimura Y, Lee C, Shinomura Y, Carbone DP, Imai K. Molecular targeting of IGF-I receptor for human pancreatic cancer. J Clin Oncol (Meeting Abstracts). 2007; 25:14051.

122. Beltran, PJ.; Mitchell, P.; Moody, G.; Lu, J.; Chung, Y.; Zhang, X.; Freeman, D.; Kendall, RL.; Calzone, FJ.; Radisnky, R. AMG-479, a fully human anti IGF-1 receptor antibody, inhibits PI3K/ Akt signaling and exerts potent antitumor effects in combination with EGF-R inhibitors in pancreatic xenograft models. ASCO Gastrointestinal Cancers Symposium; Orlando, Florida. 2007;

123. Hatakeyama S, Tomioka D, Kawahara E, Matsuura N, Masuya K, Miyake T, Umemura I, Kanazawa T, Honda T, Ohmori O. Anti-cancer activity of NVP-TAE226, a potent dual FAK/ IGF-IR kinase inhibitor, against pancreatic carcinoma. J Clin Oncol (Meeting Abstracts). 2006; 24:13162.

124. Sawai H, Okada Y, Funahashi H, Matsuo Y, Takahashi H, Takeyama H, Manabe T. Activation of focal adhesion kinase enhances the adhesion and invasion of pancreatic cancer cells via extracellular signal-regulated kinase-1/2 signaling pathway activation. Mol Cancer. 2005; 4:37. [PubMed: 16209712]

125. Furuyama K, Doi R, Mori T, Toyoda E, Ito D, Kami K, Koizumi M, Kida A, Kawaguchi Y, Fujimoto K. Clinical significance of focal adhesion kinase in resectable pancreatic cancer. World J Surg. 2006; 30:219-226. [PubMed: 16425085]

126. Duxbury MS, Ito H, Zinner MJ, Ashley SW, Whang EE. Focal adhesion kinase gene silencing promotes anoikis and suppresses metastasis of human pancreatic adenocarcinoma cells. Surgery. 2004; 135:555-562. [PubMed: 15118593]

127. Cohen SJ, Palazzo I, Meropol NJ, Rogatko A, Weiner LM, Golemis EA, Cheng JD, Alpaugh RK. Fibroblast activation protein and focal adhesion kinase: novel stromal therapeutic targets in pancreatic adenocarcinoma. J Clin Oncol (Meeting Abstracts). 2004; 22:4094. 
128. Hahn SA, Schutte M, Hoque AT, Moskaluk CA, da Costa LT, Rozenblum E, Weinstein CL, Fischer A, Yeo CJ, Hruban RH, Kern SE. DPC4, a candidate tumor suppressor gene at human chromosome 18q21.1. Science. 1996; 271:350-353. [PubMed: 8553070]

129. Schwarte-Waldhoff I, Volpert OV, Bouck NP, Sipos B, Hahn SA, Klein-Scory S, Luttges J, Kloppel G, Graeven U, Eilert-Micus C, Hintelmann A, Schmiegel W. Smad4/DPC4-mediated tumor suppression through suppression of angiogenesis. Proc Natl Acad Sci U S A. 2000; 97:9624-9629. [PubMed: 10944227]

130. Zapatka M, Zboralski D, Radacz Y, Bockmann M, Arnold C, Schoneck A, Hoppe S, Tannapfel A, Schmiegel W, Simon-Assmann P, Schwarte-Waldhoff I. Basement membrane component laminin-5 is a target of the tumor suppressor Smad4. Oncogene. 2007; 26:1417-1427. [PubMed: 16953227]

131. Duda DG, Sunamura M, Lefter LP, Furukawa T, Yokoyama T, Yatsuoka T, Abe T, Inoue H, Motoi F, Egawa S, Matsuno S, Horii A. Restoration of SMAD4 by gene therapy reverses the invasive phenotype in pancreatic adenocarcinoma cells. Oncogene. 2003; 22:6857-6864. [PubMed: 14534532]

132. Yatsuoka T, Sunamura M, Furukawa T, Fukushige S, Yokoyama T, Inoue H, Shibuya K, Takeda K, Matsuno S, Horii A. Association of poor prognosis with loss of 12q, 17p, and 18q, and concordant loss of $6 \mathrm{q} / 17 \mathrm{p}$ and $12 \mathrm{q} / 18 \mathrm{q}$ in human pancreatic ductal adenocarcinoma. Am J Gastroenterol. 2000; 95:2080-2085. [PubMed: 10950061]

133. Jazag A, Ijichi H, Kanai F, Imamura T, Guleng B, Ohta M, Imamura J, Tanaka Y, Tateishi K, Ikenoue T, Kawakami T, Arakawa Y, Miyagishi M, Taira K, Kawabe T, Omata M. Smad4 silencing in pancreatic cancer cell lines using stable RNA interference and gene expression profiles induced by transforming growth factor-beta. Oncogene. 2005; 24:662-671. [PubMed: 15592526]

134. Derynck R, Akhurst RJ, Balmain A. TGF-beta signaling in tumor suppression and cancer progression. Nat Genet. 2001; 29:117-129. [PubMed: 11586292]

135. Bierie B, Moses HL. Tumour microenvironment: TGFbeta: the molecular Jekyll and Hyde of cancer. Nat Rev Cancer. 2006; 6:506-520. [PubMed: 16794634]

136. Goggins M, Shekher M, Turnacioglu K, Yeo CJ, Hruban RH, Kern SE. Genetic alterations of the transforming growth factor beta receptor genes in pancreatic and biliary adenocarcinomas. Cancer Res. 1998; 58:5329-5332. [PubMed: 9850059]

137. Hau P, Jachimczak P, Schlingensiepen R, Schulmeyer F, Jauch T, Steinbrecher A, Brawanski A, Proescholdt M, Schlaier J, Buchroithner J, Pichler J, Wurm G, Mehdorn M, Strege R, Schuierer G, Villarrubia V, Fellner F, Jansen O, Straube T, Nohria V, Goldbrunner M, Kunst M, Schmaus S, Stauder G, Bogdahn U, Schlingensiepen KH. Inhibition of TGF-beta2 with AP 12009 in recurrent malignant gliomas: from preclinical to phase I/II studies. Oligonucleotides. 2007; 17:201-212. [PubMed: 17638524]

138. Schlingensiepen KH, Schlingensiepen R, Steinbrecher A, Hau P, Bogdahn U, Fischer-Blass B, Jachimczak P. Targeted tumor therapy with the TGF-beta2 antisense compound AP 12009. Cytokine Growth Factor Rev. 2006; 17:129-139. [PubMed: 16377233]

139. Stauder G, Bischof A, Egger T, Hafner M, Herrmuth H, Jachimczak P, Kielmanowicz M, Schlingensiepen R, Schlingensiepen KH. TGF-\{beta\}2 suppression by the antisense oligonucleotide AP 12009 as treatment for pancreatic cancer: preclinical efficacy data. J Clin Oncol (Meeting Abstracts). 2004; 22:4106.

140. Oettle H, Seufferlein T, Schmid R, Luger T, Ludwig S, Schmaus S, Wuerth G, Heinrichs H, Schlingensiepen K. Preliminary results of a phase I/II study in pancreatic carcinoma, malignant melanoma, and colorectal carcinoma with the TGF- $\{$ beta 2 inhibitor AP 12009. J Clin Oncol (Meeting Abstracts). 2007; 25:4607.

141. Taipale J, Beachy PA. The Hedgehog and Wnt signalling pathways in cancer. Nature. 2001; 411:349-354. [PubMed: 11357142]

142. Taipale J, Cooper MK, Maiti T, Beachy PA. Patched acts catalytically to suppress the activity of Smoothened. Nature. 2002; 418:892-897. [PubMed: 12192414]

143. Thayer SP, di Magliano MP, Heiser PW, Nielsen CM, Roberts DJ, Lauwers GY, Qi YP, Gysin S, Castillo C Fernandez-del, Yajnik V, Antoniu B, McMahon M, Warshaw AL, Hebrok M. 
Hedgehog is an early and late mediator of pancreatic cancer tumorigenesis. Nature. 2003; 425:851-856. [PubMed: 14520413]

144. Kayed H, Kleeff J, Keleg S, Guo J, Ketterer K, Berberat PO, Giese N, Esposito I, Giese T, Buchler MW, Friess H. Indian hedgehog signaling pathway: expression and regulation in pancreatic cancer. Int J Cancer. 2004; 110:668-676. [PubMed: 15146555]

145. Morton JP, Mongeau ME, Klimstra DS, Morris JP, Lee YC, Kawaguchi Y, Wright CV, Hebrok M, Lewis BC. Sonic hedgehog acts at multiple stages during pancreatic tumorigenesis. Proc Natl Acad Sci U S A. 2007; 104:5103-5108. [PubMed: 17372229]

146. Ji Z, Mei FC, Xie J, Cheng X. Oncogenic KRAS activates hedgehog signaling pathway in pancreatic cancer cells. J Biol Chem. 2007; 282:14048-14055. [PubMed: 17353198]

147. Berman DM, Karhadkar SS, Maitra A, De Oca R Montes, Gerstenblith MR, Briggs K, Parker AR, Shimada Y, Eshleman JR, Watkins DN, Beachy PA. Widespread requirement for Hedgehog ligand stimulation in growth of digestive tract tumours. Nature. 2003; 425:846-851. [PubMed: 14520411]

148. Shafaee Z, Schmidt H, Du W, Posner M, Weichselbaum R. Cyclopamine increases the cytotoxic effects of paclitaxel and radiation but not cisplatin and gemcitabine in Hedgehog expressing pancreatic cancer cells. Cancer Chemother Pharmacol. 2006; 58:765-770. [PubMed: 16552573]

149. Feldmann G, Dhara S, Fendrich V, Bedja D, Beaty R, Mullendore M, Karikari C, Alvarez H, Iacobuzio-Donahue C, Jimeno A, Gabrielson KL, Matsui W, Maitra A. Blockade of hedgehog signaling inhibits pancreatic cancer invasion and metastases: a new paradigm for combination therapy in solid cancers. Cancer Res. 2007; 67:2187-2196. [PubMed: 17332349]

150. Hu WG, Liu T, Xiong JX, Wang CY. Blockade of sonic hedgehog signal pathway enhances antiproliferative effect of EGFR inhibitor in pancreatic cancer cells. Acta Pharmacol Sin. 2007; 28:1224-1230. [PubMed: 17640486]

151. Chang DZ. Synthetic miRNAs targeting the GLI-1 transcription factor inhibit division and induce apoptosis in pancreatic tumor cells. AACR Meeting Abstracts. 2006; 2006:639-b.

152. Weijzen S, Rizzo P, Braid M, Vaishnav R, Jonkheer SM, Zlobin A, Osborne BA, Gottipati S, Aster JC, Hahn WC, Rudolf M, Siziopikou K, Kast WM, Miele L. Activation of Notch-1 signaling maintains the neoplastic phenotype in human Ras-transformed cells. Nat Med. 2002; 8:979-986. [PubMed: 12185362]

153. Miyamoto Y, Maitra A, Ghosh B, Zechner U, Argani P, Iacobuzio-Donahue CA, Sriuranpong V, Iso T, Meszoely IM, Wolfe MS, Hruban RH, Ball DW, Schmid RM, Leach SD. Notch mediates TGF alpha-induced changes in epithelial differentiation during pancreatic tumorigenesis. Cancer Cell. 2003; 3:565-576. [PubMed: 12842085]

154. Buchler P, Gazdhar A, Schubert M, Giese N, Reber HA, Hines OJ, Giese T, Ceyhan GO, Muller M, Buchler MW, Friess H. The Notch signaling pathway is related to neurovascular progression of pancreatic cancer. Ann Surg. 2005; 242:791-800. discussion 800-791. [PubMed: 16327489]

155. Wang Z, Zhang Y, Li Y, Banerjee S, Liao J, Sarkar FH. Down-regulation of Notch-1 contributes to cell growth inhibition and apoptosis in pancreatic cancer cells. Mol Cancer Ther. 2006; 5:483493. [PubMed: 16546962]

156. Wang Z, Banerjee S, Li Y, Rahman KM, Zhang Y, Sarkar FH. Down-regulation of notch-1 inhibits invasion by inactivation of nuclear factor-kappaB, vascular endothelial growth factor, and matrix metalloproteinase-9 in pancreatic cancer cells. Cancer Res. 2006; 66:2778-2784. [PubMed: 16510599]

157. Wang Z, Zhang Y, Banerjee S, Li Y, Sarkar FH. Notch-1 down-regulation by curcumin is associated with the inhibition of cell growth and the induction of apoptosis in pancreatic cancer cells. Cancer. 2006; 106:2503-2513. [PubMed: 16628653]

158. Doucas H, Mann CD, Sutton CD, Garcea G, Neal CP, Berry DP, Manson MM. Expression of nuclear notch3 in pancreatic adenocarcinomas is associated with adverse clinical features, and correlates with the expression of STAT3 and phosphorylated Akt. J Surg Oncol. 2007

159. Dang T, Vo k, Washington K, Berlin J. The role of Notch3 signaling pathway in pancreatic cancer. J Clin Oncol (Meeting Abstracts). 2007; 25:21049. 
160. Schweinfest CW, Graber MW, Chapman JM, Papas TS, Baron PL, Watson DK. CaSm: an Smlike protein that contributes to the transformed state in cancer cells. Cancer Res. 1997; 57:29612965. [PubMed: 9230209]

161. Gumbs AA, Bassi C, Moore PS, Falconi M, Frigerio I, Baron A, Piemonti L, Modlin I, Scarpa A. Overexpression of the Sm-like proto-oncogene in primary and metastatic pancreatic endocrine tumors. Jop. 2002; 3:109-115. [PubMed: 12110768]

162. Zaric B, Chami M, Remigy H, Engel A, Ballmer-Hofer K, Winkler FK, Kambach C. Reconstitution of two recombinant LSm protein complexes reveals aspects of their architecture, assembly, and function. J Biol Chem. 2005; 280:16066-16075. [PubMed: 15711010]

163. Kelley JR, Fraser MM, Hubbard JM, Watson DK, Cole DJ. CaSm antisense gene therapy: a novel approach for the treatment of pancreatic cancer. Anticancer Res. 2003; 23:2007-2013. [PubMed: 12894573]

164. Yan Y, Rubinchik S, Wood AL, Gillanders WE, Dong JY, Watson DK, Cole DJ. Bystander effect contributes to the antitumor efficacy of CaSm antisense gene therapy in a preclinical model of advanced pancreatic cancer. Mol Ther. 2006; 13:357-365. [PubMed: 16226492]

165. Pennati M, Folini M, Zaffaroni N. Targeting survivin in cancer therapy: fulfilled promises and open questions. Carcinogenesis. 2007; 28:1133-1139. [PubMed: 17341657]

166. Satoh K, Kaneko K, Hirota M, Masamune A, Satoh A, Shimosegawa T. Expression of survivin is correlated with cancer cell apoptosis and is involved in the development of human pancreatic duct cell tumors. Cancer. 2001; 92:271-278. [PubMed: 11466679]

167. Sarela AI, Verbeke CS, Ramsdale J, Davies CL, Markham AF, Guillou PJ. Expression of survivin, a novel inhibitor of apoptosis and cell cycle regulatory protein, in pancreatic adenocarcinoma. Br J Cancer. 2002; 86:886-892. [PubMed: 11953819]

168. Lee MA, Park GS, Lee HJ, Jung JH, Kang JH, Hong YS, Lee KS, Kim DG, Kim SN. Survivin expression and its clinical significance in pancreatic cancer. BMC Cancer. 2005; 5:127. [PubMed: 16202147]

169. Kami K, Doi R, Koizumi M, Toyoda E, Mori T, Ito D, Fujimoto K, Wada M, Miyatake S, Imamura M. Survivin expression is a prognostic marker in pancreatic cancer patients. Surgery. 2004; 136:443-448. [PubMed: 15300213]

170. Tonini G, Vincenzi B, Santini D, Scarpa S, Vasaturo T, Malacrino C, Coppola R, Magistrelli P, Borzomati D, Baldi A, Antinori A, Caricato M, Nuzzo G, Picciocchi A. Nuclear and cytoplasmic expression of survivin in 67 surgically resected pancreatic cancer patients. Br J Cancer. 2005; 92:2225-2232. [PubMed: 15928668]

171. Asanuma K, Moriai R, Yajima T, Yagihashi A, Yamada M, Kobayashi D, Watanabe N. Survivin as a radioresistance factor in pancreatic cancer. Jpn J Cancer Res. 2000; 91:1204-1209. [PubMed: 11092988]

172. Kami K, Doi R, Koizumi M, Toyoda E, Mori T, Ito D, Kawaguchi Y, Fujimoto K, Wada M, Miyatake S, Imamura M. Downregulation of survivin by siRNA diminishes radioresistance of pancreatic cancer cells. Surgery. 2005; 138:299-305. [PubMed: 16153440]

173. Guan HT, Xue XH, Dai ZJ, Wang XJ, Li A, Qin ZY. Down-regulation of survivin expression by small interfering RNA induces pancreatic cancer cell apoptosis and enhances its radiosensitivity. World J Gastroenterol. 2006; 12:2901-2907. [PubMed: 16718816]

174. Tsuji N, Asanuma K, Kobayashi D, Yagihashi A, Watanabe N. Introduction of a survivin genespecific small inhibitory RNA inhibits growth of pancreatic cancer cells. Anticancer Res. 2005; 25:3967-3972. [PubMed: 16309185]

175. Carrasco RA, Stamm NB, Rizza ME, Spencer C, Kim Y, Marcusson EG, Trask OJ, Syed S, Sandusky G, Patel BK. Antisense inhibition of survivin expression as a cancer therapeutic. AACR Meeting Abstracts. 2004; 2004:1239-a.

176. Sherr CJ. Principles of tumor suppression. Cell. 2004; 116:235-246. [PubMed: 14744434]

177. Caldas C, Hahn SA, da Costa LT, Redston MS, Schutte M, Seymour AB, Weinstein CL, Hruban RH, Yeo CJ, Kern SE. Frequent somatic mutations and homozygous deletions of the p16 (MTS1) gene in pancreatic adenocarcinoma. Nat Genet. 1994; 8:27-32. [PubMed: 7726912]

178. Craig C, Kim M, Ohri E, Wersto R, Katayose D, Li Z, Choi YH, Mudahar B, Srivastava S, Seth $\mathrm{P}$, Cowan K. Effects of adenovirus-mediated p16INK4A expression on cell cycle arrest are 
determined by endogenous p16 and Rb status in human cancer cells. Oncogene. 1998; 16:265272. [PubMed: 9464545]

179. Barton CM, McKie AB, Hogg A, Bia B, Elia G, Phillips SM, Ding SF, Lemoine NR. Abnormalities of the RB1 and DCC tumor suppressor genes: uncommon in human pancreatic adenocarcinoma. Mol Carcinog. 1995; 13:61-69. [PubMed: 7605581]

180. Kobayashi S, Shirasawa H, Sashiyama H, Kawahira H, Kaneko K, Asano T, Ochiai T. P16INK4a expression adenovirus vector to suppress pancreas cancer cell proliferation. Clin Cancer Res. 1999; 5:4182-4185. [PubMed: 10632358]

181. Joshi US, Dergham ST, Chen YQ, Dugan MC, Crissman JD, Vaitkevicius VK, Sarkar FH. Inhibition of pancreatic tumor cell growth in culture by p21WAF1 recombinant adenovirus. Pancreas. 1998; 16:107-113. [PubMed: 9510131]

182. Sohn TA, Yeo CJ. The molecular genetics of pancreatic ductal carcinoma: a review. Surg Oncol. 2000; 9:95-101. [PubMed: 11356337]

183. Christophorou MA, Ringshausen I, Finch AJ, Swigart LB, Evan GI. The pathological response to DNA damage does not contribute to p53-mediated tumour suppression. Nature. 2006; 443:214217. [PubMed: 16957739]

184. Peng Z. Current status of gendicine in China: recombinant human Ad-p53 agent for treatment of cancers. Hum Gene Ther. 2005; 16:1016-1027. [PubMed: 16149900]

185. Bouvet M, Bold RJ, Lee J, Evans DB, Abbruzzese JL, Chiao PJ, McConkey DJ, Chandra J, Chada S, Fang B, Roth JA. Adenovirus-mediated wild-type p53 tumor suppressor gene therapy induces apoptosis and suppresses growth of human pancreatic cancer [seecomments]. Ann Surg Oncol. 1998; 5:681-688. [PubMed: 9869513]

186. Hwang RF, Gordon EM, Anderson WF, Parekh D. Gene therapy for primary and metastatic pancreatic cancer with intraperitoneal retroviral vector bearing the wild-type p53 gene. Surgery. 1998; 124:143-150. discussion 150-141. [PubMed: 9706132]

187. Cascallo M, Calbo J, Gelpi JL, Mazo A. Modulation of drug cytotoxicity by reintroduction of wild-type p53 gene (Ad5CMV-p53) in human pancreatic cancer. Cancer Gene Ther. 2000; 7:545-556. [PubMed: 10811472]

188. Durfee T, Mancini MA, Jones D, Elledge SJ, Lee WH. The amino-terminal region of the retinoblastoma gene product binds a novel nuclear matrix protein that co-localizes to centers for RNA processing. J Cell Biol. 1994; 127:609-622. [PubMed: 7525595]

189. Yin S, Goodrich DW. Combination gene therapy with p53 and Thoc1/p84 is more effective than either single agent in an animal model of human pancreatic adenocarcinoma. Int J Oncol. 2006; 28:781-785. [PubMed: 16465385]

190. Ito Y, Takeda T, Wakasa K, Tsujimoto M, Sakon M, Matsuura N. Expression of p73 and p63 proteins in pancreatic adenocarcinoma: $\mathrm{p} 73$ overexpression is inversely correlated with biological aggressiveness. Int J Mol Med. 2001; 8:67-71. [PubMed: 11408952]

191. Rodicker F, Putzer BM. p73 is effective in p53-null pancreatic cancer cells resistant to wild-type TP53 gene replacement. Cancer Res. 2003; 63:2737-2741. [PubMed: 12782576]

192. Craperi D, Vicat JM, Nissou MF, Mathieu J, Baudier J, Benabid AL, Verna JM. Increased bax expression is associated with cell death induced by ganciclovir in a herpes thymidine kinase gene-expressing glioma cell line. Hum Gene Ther. 1999; 10:679-688. [PubMed: 10094211]

193. Wang J, Lu XX, Chen DZ, Li SF, Zhang LS. Herpes simplex virus thymidine kinase and ganciclovir suicide gene therapy for human pancreatic cancer. World J Gastroenterol. 2004; 10:400-403. [PubMed: 14760766]

194. Makinen K, Loimas S, Wahlfors J, Alhava E, Janne J. Evaluation of herpes simplex thymidine kinase mediated gene therapy in experimental pancreatic cancer. J Gene Med. 2000; 2:361-367. [PubMed: 11045430]

195. Rosenfeld ME, Vickers SM, Raben D, Wang M, Sampson L, Feng M, Jaffee E, Curiel DT. Pancreatic carcinoma cell killing via adenoviral mediated delivery of the herpes simplex virus thymidine kinase gene. Ann Surg. 1997; 225:609-618. discussion 618-620. [PubMed: 9193188]

196. Block A, Chen SH, Kosai K, Finegold M, Woo SL. Adenoviral-mediated herpes simplex virus thymidine kinase gene transfer: regression of hepatic metastasis of pancreatic tumors. Pancreas. 1997; 15:25-34. [PubMed: 9211489] 
197. Carrio M, Romagosa A, Mercade E, Mazo A, Nadal M, Gomez-Foix AM, Fillat C. Enhanced pancreatic tumor regression by a combination of adenovirus and retrovirus-mediated delivery of the herpes simplex virus thymidine kinase gene. Gene Ther. 1999; 6:547-553. [PubMed: 10476214]

198. Aoki K, Yoshida T, Matsumoto N, Ide H, Hosokawa K, Sugimura T, Terada M. Gene therapy for peritoneal dissemination of pancreatic cancer by liposome-mediated transfer of herpes simplex virus thymidine kinase gene. Hum Gene Ther. 1997; 8:1105-1113. [PubMed: 9189768]

199. Greco E, Fogar P, Basso D, Stefani AL, Navaglia F, Zambon CF, Mazza S, Gallo N, Piva MG, Scarpa A, Pedrazzoli S, Plebani M. Retrovirus-mediated herpes simplex virus thymidine kinase gene transfer in pancreatic cancer cell lines: an incomplete antitumor effect. Pancreas. 2002; 25:e21-29. [PubMed: 12142751]

200. Fogar P, Greco E, Basso D, Habeler W, Navaglia F, Zambon CF, Tormen D, Gallo N, Cecchetto A, Plebani M, Pedrazzoli S. Suicide gene therapy with HSV-TK in pancreatic cancer has no effect in vivo in a mouse model. Eur J Surg Oncol. 2003; 29:721-730. [PubMed: 14602490]

201. Evoy D, Hirschowitz EA, Naama HA, Li XK, Crystal RG, Daly JM, Lieberman MD. In vivo adenoviral-mediated gene transfer in the treatment of pancreatic cancer. J Surg Res. 1997; 69:226-231. [PubMed: 9202675]

202. Li ZS, Pan X, Xu GM, Cui L, Dai GR, Gong YF, Tu ZX. Killing effects of cytosine deaminase gene mediated by adenovirus vector on human pancreatic cancer cell lines in vitro. Hepatobiliary Pancreat Dis Int. 2003; 2:147-151. [PubMed: 14607669]

203. Zhang SN, Yuan SZ, Zhu ZH, Wen ZF, Huang ZQ, Zeng ZY. Apoptosis induced by 5-flucytosine in human pancreatic cancer cells genetically modified to express cytosine deaminase. Acta Pharmacol Sin. 2000; 21:655-659. [PubMed: 11360677]

204. Harris JD, Gutierrez AA, Hurst HC, Sikora K, Lemoine NR. Gene therapy for cancer using tumour-specific prodrug activation. Gene Ther. 1994; 1:170-175. [PubMed: 7584078]

205. Erbs P, Regulier E, Kintz J, Leroy P, Poitevin Y, Exinger F, Jund R, Mehtali M. In vivo cancer gene therapy by adenovirus-mediated transfer of a bifunctional yeast cytosine deaminase/uracil phosphoribosyltransferase fusion gene. Cancer Res. 2000; 60:3813-3822. [PubMed: 10919655]

206. Fogar P, Navaglia F, Basso D, Greco E, Zambon CF, Fadi E, Falda A, Stranges A, Vannozzi F, Danesi R, Pedrazzoli S, Plebani M. Suicide gene therapy with the yeast fusion gene cytosine deaminase/uracil phosphoribosyltransferase is not enough for pancreatic cancer. Pancreas. 2007; 35:224-231. [PubMed: 17895842]

207. Sunamura M, Oonuma M, Motoi F, Abe H, Saitoh Y, Hoshida T, Ottomo S, Horii A, Matsuno S. Gene therapy for pancreatic cancer targeting the genomic alterations of tumor suppressor genes using replication-selective oncolytic adenovirus. Hum Cell. 2002; 15:138-150. [PubMed: 12703544]

208. Grove JI, Searle PF, Weedon SJ, Green NK, McNeish IA, Kerr DJ. Virus-directed enzyme prodrug therapy using CB1954. Anticancer Drug Des. 1999; 14:461-472. [PubMed: 10834268]

209. Green NK, Youngs DJ, Neoptolemos JP, Friedlos F, Knox RJ, Springer CJ, Anlezark GM, Michael NP, Melton RG, Ford MJ, Young LS, Kerr DJ, Searle PF. Sensitization of colorectal and pancreatic cancer cell lines to the prodrug 5-(aziridin-1-yl)-2,4-dinitrobenzamide (CB1954) by retroviral transduction and expression of the E. coli nitroreductase gene. Cancer Gene Ther. 1997; 4:229-238. [PubMed: 9253508]

210. McNeish IA, Green NK, Gilligan MG, Ford MJ, Mautner V, Young LS, Kerr DJ, Searle PF. Virus directed enzyme prodrug therapy for ovarian and pancreatic cancer using retrovirally delivered E. coli nitroreductase and CB1954. Gene Ther. 1998; 5:1061-1069. [PubMed: 10326029]

211. Weedon SJ, Green NK, McNeish IA, Gilligan MG, Mautner V, Wrighton CJ, Mountain A, Young LS, Kerr DJ, Searle PF. Sensitisation of human carcinoma cells to the prodrug CB1954 by adenovirus vector-mediated expression of E. coli nitroreductase. Int J Cancer. 2000; 86:848-854. [PubMed: 10842200]

212. Hicklin DJ, Ellis LM. Role of the vascular endothelial growth factor pathway in tumor growth and angiogenesis. J Clin Oncol. 2005; 23:1011-1027. [PubMed: 15585754] 
213. Seo Y, Baba H, Fukuda T, Takashima M, Sugimachi K. High expression of vascular endothelial growth factor is associated with liver metastasis and a poor prognosis for patients with ductal pancreatic adenocarcinoma. Cancer. 2000; 88:2239-2245. [PubMed: 10820344]

214. Dvorak HF. Vascular permeability factor/vascular endothelial growth factor: a critical cytokine in tumor angiogenesis and a potential target for diagnosis and therapy. J Clin Oncol. 2002; 20:4368-4380. [PubMed: 12409337]

215. Ferrara N, Gerber HP, LeCouter J. The biology of VEGF and its receptors. Nat Med. 2003; 9:669-676. [PubMed: 12778165]

216. Takayama K, Ueno H, Nakanishi Y, Sakamoto T, Inoue K, Shimizu K, Oohashi H, Hara N. Suppression of tumor angiogenesis and growth by gene transfer of a soluble form of vascular endothelial growth factor receptor into a remote organ. Cancer Res. 2000; 60:2169-2177. [PubMed: 10786681]

217. Tseng JF, Farnebo FA, Kisker O, Becker CM, Kuo CJ, Folkman J, Mulligan RC. Adenovirusmediated delivery of a soluble form of the VEGF receptor Flk1 delays the growth of murine and human pancreatic adenocarcinoma in mice. Surgery. 2002; 132:857-865. [PubMed: 12464871]

218. Buchler P, Reber HA, Ullrich A, Shiroiki M, Roth M, Buchler MW, Lavey RS, Friess H, Hines OJ. Pancreatic cancer growth is inhibited by blockade of VEGF-RII. Surgery. 2003; 134:772782. [PubMed: 14639356]

219. Hotz HG, Hines OJ, Masood R, Hotz B, Foitzik T, Buhr HJ, Gill PS, Reber HA. VEGF antisense therapy inhibits tumor growth and improves survival in experimental pancreatic cancer. Surgery. 2005; 137:192-199. [PubMed: 15674201]

220. Baker CH, Solorzano CC, Fidler IJ. Blockade of vascular endothelial growth factor receptor and epidermal growth factor receptor signaling for therapy of metastatic human pancreatic cancer. Cancer Res. 2002; 62:1996-2003. [PubMed: 11929816]

221. Solorzano CC, Baker CH, Bruns CJ, Killion JJ, Ellis LM, Wood J, Fidler IJ. Inhibition of growth and metastasis of human pancreatic cancer growing in nude mice by PTK 787/ZK222584, an inhibitor of the vascular endothelial growth factor receptor tyrosine kinases. Cancer Biother Radiopharm. 2001; 16:359-370. [PubMed: 11776753]

222. Bocci G, Danesi R, Marangoni G, Fioravanti A, Boggi U, Esposito I, Fasciani A, Boschi E, Campani D, Bevilacqua G, Mosca F, Del Tacca M. Antiangiogenic versus cytotoxic therapeutic approaches to human pancreas cancer: an experimental study with a vascular endothelial growth factor receptor-2 tyrosine kinase inhibitor and gemcitabine. Eur J Pharmacol. 2004; 498:9-18. [PubMed: 15363970]

223. Conrad C, Ischenko I, Kohl G, Wiegand U, Guba M, Yezhelyev M, Ryan AJ, Barge A, Geissler EK, Wedge SR, Jauch KW, Bruns CJ. Antiangiogenic and antitumor activity of a novel vascular endothelial growth factor receptor-2 tyrosine kinase inhibitor ZD6474 in a metastatic human pancreatic tumor model. Anticancer Drugs. 2007; 18:569-579. [PubMed: 17414626]

224. Bianco C, Giovannetti E, Ciardiello F, Mey V, Nannizzi S, Tortora G, Troiani T, Pasqualetti F, Eckhardt G, de Liguoro M, Ricciardi S, Del Tacca M, Raben D, Cionini L, Danesi R. Synergistic antitumor activity of ZD6474, an inhibitor of vascular endothelial growth factor receptor and epidermal growth factor receptor signaling, with gemcitabine and ionizing radiation against pancreatic cancer. Clin Cancer Res. 2006; 12:7099-7107. [PubMed: 17145834]

225. Yao VJ, Ozawa MG, Varner AS, Kasman IM, Chanthery YH, Pasqualini R, Arap W, McDonald DM. Antiangiogenic therapy decreases integrin expression in normalized tumor blood vessels. Cancer Res. 2006; 66:2639-2649. [PubMed: 16510583]

226. Yamazaki S, Grazzini ML, Romero D, Amundson K, Pithavala Y, Hu-Lowe DD. PK/PD modeling based on mouse xenograft tumor growth inhibition and the correlation to clinical exposure for VEGF/PDGF receptor tyrosine kinase inhibitor AG-013736. AACR Meeting Abstracts. 2005; 2005:705-c-706.

227. Hu-Lowe DD, Grazzini ML. Significant enhancement of anti-tumor efficacy of VEGF/PDGF receptor tyrosine kinase inhibitor AG-013736 in combination with docetaxel in chemo-refractory and/or orthotopic xenograft tumor models in mice. AACR Meeting Abstracts. 2005; 2005:475-d476.

228. Inai T, Mancuso M, Hashizume H, Baffert F, Haskell A, Baluk P, Hu-Lowe DD, Shalinsky DR, Thurston G, Yancopoulos GD, McDonald DM. Inhibition of Vascular Endothelial Growth Factor 
(VEGF) Signaling in Cancer Causes Loss of Endothelial Fenestrations, Regression of Tumor Vessels, and Appearance of Basement Membrane Ghosts. Am J Pathol. 2004; 165:35-52. [PubMed: 15215160]

229. Spano J, Chodkiewicz C, Maurel J, Wong RP, Wasan HS, Pithavala YK, Bycott PW, Liau K, Kim S, Rixe O. A randomized phase II study of axitinib (AG-013736) and gemcitabine versus gemcitabine in advanced pancreatic cancer, preceded by a phase I component. J Clin Oncol (Meeting Abstracts). 2007; 25:4551.

230. Wilhelm SM, Carter C, Tang L, Wilkie D, McNabola A, Rong H, Chen C, Zhang X, Vincent P, McHugh M, Cao Y, Shujath J, Gawlak S, Eveleigh D, Rowley B, Liu L, Adnane L, Lynch M, Auclair D, Taylor I, Gedrich R, Voznesensky A, Riedl B, Post LE, Bollag G, Trail PA. BAY 43-9006 Exhibits Broad Spectrum Oral Antitumor Activity and Targets the RAF/MEK/ERK Pathway and Receptor Tyrosine Kinases Involved in Tumor Progression and Angiogenesis. Cancer Res. 2004; 64:7099-7109. [PubMed: 15466206]

231. Wallace JA, Locker G, Nattam S, Kasza K, Wade-Oliver K, Stadler WM, Vokes EE, Kindler HL. Sorafenib (S) plus gemcitabine (G) for advanced pancreatic cancer (PC): A phase II trial of the University of Chicago Phase II Consortium. J Clin Oncol (Meeting Abstracts). 2007; 25:4608.

232. Kuba K, Matsumoto K, Date K, Shimura H, Tanaka M, Nakamura T. HGF/NK4, a four-kringle antagonist of hepatocyte growth factor, is an angiogenesis inhibitor that suppresses tumor growth and metastasis in mice. Cancer Res. 2000; 60:6737-6743. [PubMed: 11118060]

233. Furukawa T, Duguid WP, Kobari M, Matsuno S, Tsao MS. Hepatocyte growth factor and Met receptor expression in human pancreatic carcinogenesis. Am J Pathol. 1995; 147:889-895. [PubMed: 7573364]

234. Di Renzo MF, Poulsom R, Olivero M, Comoglio PM, Lemoine NR. Expression of the Met/ hepatocyte growth factor receptor in human pancreatic cancer. Cancer Res. 1995; 55:1129-1138. [PubMed: 7866999]

235. Ebert M, Yokoyama M, Friess H, Buchler MW, Korc M. Coexpression of the c-met protooncogene and hepatocyte growth factor in human pancreatic cancer. Cancer Res. 1994; 54:57755778. [PubMed: 7954397]

236. Tomioka D, Maehara N, Kuba K, Mizumoto K, Tanaka M, Matsumoto K, Nakamura T. Inhibition of growth, invasion, and metastasis of human pancreatic carcinoma cells by NK4 in an orthotopic mouse model. Cancer Res. 2001; 61:7518-7524. [PubMed: 11606388]

237. Maehara N, Matsumoto K, Kuba K, Mizumoto K, Tanaka M, Nakamura T. NK4, a four-kringle antagonist of HGF, inhibits spreading and invasion of human pancreatic cancer cells. $\mathrm{Br} \mathbf{J}$ Cancer. 2001; 84:864-873. [PubMed: 11259105]

238. Saimura M, Nagai E, Mizumoto K, Maehara N, Minamishima YA, Katano M, Matsumoto K, Nakamura T, Tanaka M. Tumor suppression through angiogenesis inhibition by SUIT-2 pancreatic cancer cells genetically engineered to secrete NK4. Clin Cancer Res. 2002; 8:32433249. [PubMed: 12374695]

239. Maehara N, Nagai E, Mizumoto K, Sato N, Matsumoto K, Nakamura T, Narumi K, Nukiwa T, Tanaka M. Gene transduction of NK4, HGF antagonist, inhibits in vitro invasion and in vivo growth of human pancreatic cancer. Clin Exp Metastasis. 2002; 19:417-426. [PubMed: 12198770]

240. Murakami M, Nagai E, Mizumoto K, Saimura M, Ohuchida K, Inadome N, Matsumoto K, Nakamura T, Maemondo M, Nukiwa T, Tanaka M. Suppression of metastasis of human pancreatic cancer to the liver by transportal injection of recombinant adenoviral NK4 in nude mice. Int J Cancer. 2005; 117:160-165. [PubMed: 15880501]

241. Saimura M, Nagai E, Mizumoto K, Maehara N, Okino H, Katano M, Matsumoto K, Nakamura T, Narumi K, Nukiwa T, Tanaka M. Intraperitoneal injection of adenovirus-mediated NK4 gene suppresses peritoneal dissemination of pancreatic cancer cell line AsPC-1 in nude mice. Cancer Gene Ther. 2002; 9:799-806. [PubMed: 12224019]

242. Ogura Y, Mizumoto K, Nagai E, Murakami M, Inadome N, Saimura M, Matsumoto K, Nakamura T, Maemondo M, Nukiwa T, Tanaka M. Peritumoral injection of adenovirus vector expressing NK4 combined with gemcitabine treatment suppresses growth and metastasis of human pancreatic cancer cells implanted orthotopically in nude mice and prolongs survival. Cancer Gene Ther. 2006; 13:520-529. [PubMed: 16341142] 
243. Garcia A, Rosen L, Cunningham CC, Nemunaitis J, Li C, Rulewski N, Dovholuk A, Savage R, Chan T, Bukowksi R, Mekhail T. Phase 1 study of ARQ 197, a selective inhibitor of the c-Met RTK in patients with metastatic solid tumors reaches recommended phase 2 dose. J Clin Oncol (Meeting Abstracts). 2007; 25:3525.

244. Ingber D, Fujita T, Kishimoto S, Sudo K, Kanamaru T, Brem H, Folkman J. Synthetic analogues of fumagillin that inhibit angiogenesis and suppress tumour growth. Nature. 1990; 348:555-557. [PubMed: 1701033]

245. Shishido T, Yasoshima T, Denno R, Mukaiya M, Sato N, Hirata K. Inhibition of liver metastasis of human pancreatic carcinoma by angiogenesis inhibitor TNP-470 in combination with cisplatin. Jpn J Cancer Res. 1998; 89:963-969. [PubMed: 9818033]

246. Kawarada Y, Ishikura H, Kishimoto T, Saito K, Takahashi T, Kato H, Yoshiki T. Inhibitory effects of the antiangiogenic agent TNP-470 on establishment and growth of hematogenous metastasis of human pancreatic carcinoma in SCID beige mice in vivo. Pancreas. 1997; 15:251257. [PubMed: 9336788]

247. Hotz HG, Reber HA, Hotz B, Sanghavi PC, Yu T, Foitzik T, Buhr HJ, Hines OJ. Angiogenesis inhibitor TNP-470 reduces human pancreatic cancer growth. J Gastrointest Surg. 2001; 5:131138. [PubMed: 11331474]

248. Jia L, Zhang MH, Yuan SZ, Huang WG. Antiangiogenic therapy for human pancreatic carcinoma xenografts in nude mice. World J Gastroenterol. 2005; 11:447-450. [PubMed: 15637766]

249. Stupp R, Ruegg C. Integrin inhibitors reaching the clinic. J Clin Oncol. 2007; 25:1637-1638. [PubMed: 17470853]

250. Friedlander M, Brooks PC, Shaffer RW, Kincaid CM, Varner JA, Cheresh DA. Definition of two angiogenic pathways by distinct alpha $v$ integrins. Science. 1995; 270:1500-1502. [PubMed: 7491498]

251. Eskens FA, Dumez H, Hoekstra R, Perschl A, Brindley C, Bottcher S, Wynendaele W, Drevs J, Verweij J, van Oosterom AT. Phase I and pharmacokinetic study of continuous twice weekly intravenous administration of Cilengitide (EMD 121974), a novel inhibitor of the integrins alphavbeta3 and alphavbeta5 in patients with advanced solid tumours. Eur J Cancer. 2003; 39:917-926. [PubMed: 12706360]

252. Friess H, Langrehr JM, Oettle H, Raedle J, Niedergethmann M, Dittrich C, Hossfeld DK, Stoger H, Neyns B, Herzog P, Piedbois P, Dobrowolski F, Scheithauer W, Hawkins R, Katz F, Balcke P, Vermorken J, van Belle S, Davidson N, Esteve AA, Castellano D, Kleeff J, Tempia-Caliera AA, Kovar A, Nippgen J. A randomized multi-center phase II trial of the angiogenesis inhibitor Cilengitide (EMD 121974) and gemcitabine compared with gemcitabine alone in advanced unresectable pancreatic cancer. BMC Cancer. 2006; 6:285. [PubMed: 17156477]

253. Mueller MM, Fusenig NE. Friends or foes -bipolar effects of the tumour stroma in cancer. Nat Rev Cancer. 2004; 4:839-849. [PubMed: 15516957]

254. Bramhall SR, Neoptolemos JP, Stamp GW, Lemoine NR. Imbalance of expression of matrix metalloproteinases (MMPs) and tissue inhibitors of the matrix metalloproteinases (TIMPs) in human pancreatic carcinoma. J Pathol. 1997; 182:347-355. [PubMed: 9349239]

255. Kilian M, Gregor JI, Heukamp I, Hanel M, Ahlgrimm M, Schimke I, Kristiansen G, Ommer A, Walz MK, Jacobi CA, Wenger FA. Matrix metalloproteinase inhibitor RO 28-2653 decreases liver metastasis by reduction of MMP-2 and MMP-9 concentration in BOP-induced ductal pancreatic cancer in Syrian Hamsters: inhibition of matrix metalloproteinases in pancreatic cancer. Prostaglandins Leukot Essent Fatty Acids. 2006; 75:429-434. [PubMed: 17034997]

256. Qian LW, Mizumoto K, Urashima T, Nagai E, Maehara N, Sato N, Nakajima M, Tanaka M. Radiation-induced increase in invasive potential of human pancreatic cancer cells and its blockade by a matrix metalloproteinase inhibitor, CGS27023. Clin Cancer Res. 2002; 8:12231227. [PubMed: 11948136]

257. Mirzaie M, Herse B, Oster O, Schondube F. The matrix metalloproteinase inhibitor batimastat inhibits the lung colonisation of orthotopically implanted malignant pancreatic tumor cells in SCID mice. Swiss Surg. 2002; 8:165-170. [PubMed: 12227109]

258. Matsushita A, Onda M, Uchida E, Maekawa R, Yoshioka T. Antitumor effect of a new selective matrix metalloproteinase inhibitor, MMI-166, on experimental pancreatic cancer. Int J Cancer. 2001; 92:434-440. [PubMed: 11291083] 
259. Alves F, Borchers U, Padge B, Augustin H, Nebendahl K, Kloppel G, Tietze LF. Inhibitory effect of a matrix metalloproteinase inhibitor on growth and spread of human pancreatic ductal adenocarcinoma evaluated in an orthotopic severe combined immunodeficient (SCID) mouse model. Cancer Lett. 2001; 165:161-170. [PubMed: 11275365]

260. Bramhall SR, Rosemurgy A, Brown PD, Bowry C, Buckels JA. Marimastat as first-line therapy for patients with unresectable pancreatic cancer: a randomized trial. J Clin Oncol. 2001; 19:3447-3455. [PubMed: 11481349]

261. Bramhall SR, Schulz J, Nemunaitis J, Brown PD, Baillet M, Buckels JA. A double-blind placebocontrolled, randomised study comparing gemcitabine and marimastat with gemcitabine and placebo as first line therapy in patients with advanced pancreatic cancer. Br J Cancer. 2002; 87:161-167. [PubMed: 12107836]

262. Moore MJ, Hamm J, Dancey J, Eisenberg PD, Dagenais M, Fields A, Hagan K, Greenberg B, Colwell B, Zee B, Tu D, Ottaway J, Humphrey R, Seymour L. Comparison of gemcitabine versus the matrix metalloproteinase inhibitor BAY 12-9566 in patients with advanced or metastatic adenocarcinoma of the pancreas: a phase III trial of the National Cancer Institute of Canada Clinical Trials Group. J Clin Oncol. 2003; 21:3296-3302. [PubMed: 12947065]

263. Kirn D. Replication-selective oncolytic adenoviruses: virotherapy aimed at genetic targets in cancer. Oncogene. 2000; 19:6660-6669. [PubMed: 11426652]

264. Everts B, van der Poel HG. Replication-selective oncolytic viruses in the treatment of cancer. Cancer Gene Ther. 2005; 12:141-161. [PubMed: 15472714]

265. Mulvihill S, Warren R, Venook A, Adler A, Randlev B, Heise C, Kirn D. Safety and feasibility of injection with an E1B-55 kDa gene-deleted, replication-selective adenovirus (ONYX-015) into primary carcinomas of the pancreas: a phase I trial. Gene Ther. 2001; 8:308-315. [PubMed: 11313805]

266. Hecht JR, Bedford R, Abbruzzese JL, Lahoti S, Reid TR, Soetikno RM, Kirn DH, Freeman SM. A phase I/II trial of intratumoral endoscopic ultrasound injection of ONYX-015 with intravenous gemcitabine in unresectable pancreatic carcinoma. Clin Cancer Res. 2003; 9:555-561. [PubMed: 12576418]

267. Lamont JP, Nemunaitis J, Kuhn JA, Landers SA, McCarty TM. A prospective phase II trial of ONYX-015 adenovirus and chemotherapy in recurrent squamous cell carcinoma of the head and neck (the Baylor experience). Ann Surg Oncol. 2000; 7:588-592. [PubMed: 11005557]

268. Nemunaitis J, Cunningham C, Buchanan A, Blackburn A, Edelman G, Maples P, Netto G, Tong A, Randlev B, Olson S, Kirn D. Intravenous infusion of a replication-selective adenovirus (ONYX-015) in cancer patients: safety, feasibility and biological activity. Gene Ther. 2001; 8:746-759. [PubMed: 11420638]

269. Reid T, Galanis E, Abbruzzese J, Sze D, Andrews J, Romel L, Hatfield M, Rubin J, Kirn D. Intraarterial administration of a replication-selective adenovirus (d11520) in patients with colorectal carcinoma metastatic to the liver: a phase I trial. Gene Ther. 2001; 8:1618-1626. [PubMed: 11895000]

270. Heise C, Ganly I, Kim YT, Sampson-Johannes A, Brown R, Kirn D. Efficacy of a replicationselective adenovirus against ovarian carcinomatosis is dependent on tumor burden, viral replication and p53 status. Gene Ther. 2000; 7:1925-1929. [PubMed: 11127580]

271. Harada JN, Berk AJ. p53-Independent and -dependent requirements for E1B-55K in adenovirus type 5 replication. J Virol. 1999; 73:5333-5344. [PubMed: 10364280]

272. O'Shea CC, Johnson L, Bagus B, Choi S, Nicholas C, Shen A, Boyle L, Pandey K, Soria C, Kunich J, Shen Y, Habets G, Ginzinger D, McCormick F. Late viral RNA export, rather than p53 inactivation, determines ONYX-015 tumor selectivity. Cancer Cell. 2004; 6:611-623. [PubMed: 15607965]

273. Mineta T, Rabkin SD, Yazaki T, Hunter WD, Martuza RL. Attenuated multi-mutated herpes simplex virus-1 for the treatment of malignant gliomas. Nat Med. 1995; 1:938-943. [PubMed: 7585221]

274. Lee JH, Federoff HJ, Schoeniger LO. G207, modified herpes simplex virus type 1, kills human pancreatic cancer cells in vitro. J Gastrointest Surg. 1999; 3:127-131. discussion 132-123. [PubMed: 10457334] 
275. McAuliffe PF, Jarnagin WR, Johnson P, Delman KA, Federoff H, Fong Y. Effective treatment of pancreatic tumors with two multimutated herpes simplex oncolytic viruses. J Gastrointest Surg. 2000; 4:580-588. [PubMed: 11307092]

276. Kasuya H, Nishiyama Y, Nomoto S, Hosono J, Takeda S, Nakao A. Intraperitoneal delivery of hrR3 and ganciclovir prolongs survival in mice with disseminated pancreatic cancer. J Surg Oncol. 1999; 72:136-141. [PubMed: 10562359]

277. Watanabe I, Kasuya H, Nomura N, Shikano T, Shirota T, Kanazumi N, Takeda S, Nomoto S, Sugimoto H, Nakao A. Effects of tumor selective replication-competent herpes viruses in combination with gemcitabine on pancreatic cancer. Cancer Chemother Pharmacol. 2007

278. Fu X, Tao L, Li M, Fisher WE, Zhang X. Effective treatment of pancreatic cancer xenografts with a conditionally replicating virus derived from type 2 herpes simplex virus. Clin Cancer Res. 2006; 12:3152-3157. [PubMed: 16707615]

279. Smith CC, Nelson J, Aurelian L, Gober M, Goswami BB. Ras-GAP binding and phosphorylation by herpes simplex virus type 2 RR1 PK (ICP10) and activation of the Ras/MEK/MAPK mitogenic pathway are required for timely onset of virus growth. J Virol. 2000; 74:10417-10429. [PubMed: 11044086]

280. Leopardi R, Van Sant C, Roizman B. The herpes simplex virus 1 protein kinase US3 is required for protection from apoptosis induced by the virus. Proc Natl Acad Sci U S A. 1997; 94:78917896. [PubMed: 9223283]

281. Kasuya H, Nishiyama Y, Nomoto S, Goshima F, Takeda S, Watanabe I, Nomura N, Shikano T, Fujii T, Kanazumi N, Nakao A. Suitability of a US3-inactivated HSV mutant (L1BR1) as an oncolytic virus for pancreatic cancer therapy. Cancer Gene Ther. 2007; 14:533-542. [PubMed: 17415379]

282. Kami K, Doi R, Miyatake S, Imamura M. Viral therapy for human pancreatic cancer cells in vitro by a conditionally replication-competent herpes simplex virus 1 vector using survivin promoter. AACR Meeting Abstracts. 2004; 2004:1062-e-1063.

283. Strong JE, Coffey MC, Tang D, Sabinin P, Lee PW. The molecular basis of viral oncolysis: usurpation of the Ras signaling pathway by reovirus. Embo J. 1998; 17:3351-3362. [PubMed: 9628872]

284. Etoh T, Himeno Y, Matsumoto T, Aramaki M, Kawano K, Nishizono A, Kitano S. Oncolytic viral therapy for human pancreatic cancer cells by reovirus. Clin Cancer Res. 2003; 9:12181223. [PubMed: 12631628]

285. Himeno Y, Etoh T, Matsumoto T, Ohta M, Nishizono A, Kitano S. Efficacy of oncolytic reovirus against liver metastasis from pancreatic cancer in immunocompetent models. Int J Oncol. 2005; 27:901-906. [PubMed: 16142304]

286. Lindenmann J, Klein PA. Viral oncolysis: increased immunogenicity of host cell antigen associated with influenza virus. J Exp Med. 1967; 126:93-108. [PubMed: 4290961]

287. Shankaran V, Ikeda H, Bruce AT, White JM, Swanson PE, Old LJ, Schreiber RD. IFNgamma and lymphocytes prevent primary tumour development and shape tumour immunogenicity. Nature. 2001; 410:1107-1111. [PubMed: 11323675]

288. Philip PA, Benedetti J, Fenoglio-Preiser C, Zalupski M, Lenz H, O’Reilly E, Wong R, Atkins J, Abruzzese J, Blanke C. Phase III study of gemcitabine [G] plus cetuximab [C] versus gemcitabine in patients [pts] with locally advanced or metastatic pancreatic adenocarcinoma [PC]: SWOG S0205 study. J Clin Oncol (Meeting Abstracts). 2007; 25:LBA4509.

289. Krempien R, Munter MW, Timke C, Friess H, Hartung G, Herfarth KK, Abdollahi A, Buchler MW, Huber PE, Debus J. Cetuximab in combination with intensity modulated radiotherapy (IMRT) and gemcitabine for patients with locally advanced pancreatic cancer: A prospective phase II trial [PARC-Study ISRCTN56652283]. J Clin Oncol (Meeting Abstracts). 2007; 25:4573.

290. Buchsbaum DJ, Bonner JA, Grizzle WE, Stackhouse MA, Carpenter M, Hicklin DJ, Bohlen P, Raisch KP. Treatment of pancreatic cancer xenografts with Erbitux (IMC-C225) anti-EGFR antibody, gemcitabine, and radiation. Int J Radiat Oncol Biol Phys. 2002; 54:1180-1193. [PubMed: 12419447] 
291. Bangard C, Gossmann A, Papyan A, Tawadros S, Hellmich M, Bruns CJ. Magnetic resonance imaging in an orthotopic rat model: blockade of epidermal growth factor receptor with EMD72000 inhibits human pancreatic carcinoma growth. Int J Cancer. 2005; 114:131-138. [PubMed: 15523683]

292. Graeven U, Kremer B, Sudhoff T, Killing B, Rojo F, Weber D, Tillner J, Unal C, Schmiegel W. Phase I study of the humanised anti-EGFR monoclonal antibody matuzumab (EMD 72000) combined with gemcitabine in advanced pancreatic cancer. Br J Cancer. 2006; 94:1293-1299. [PubMed: 16622465]

293. Kindler HL, Friberg G, Singh DA, Locker G, Nattam S, Kozloff M, Taber DA, Karrison T, Dachman A, Stadler WM, Vokes EE. Phase II trial of bevacizumab plus gemcitabine in patients with advanced pancreatic cancer. J Clin Oncol. 2005; 23:8033-8040. [PubMed: 16258101]

294. Kindler HL, Niedzwiecki D, Hollis D, Oraefo E, Schrag D, Hurwitz H, McLeod HL, Mulcahy MF, Schilsky RL, Goldberg RM, Cancer and Leukemia Group B. A double-blind, placebocontrolled, randomized phase III trial of gemcitabine $(\mathrm{G})$ plus bevacizumab (B) versus gemcitabine plus placebo $(\mathrm{P})$ in patients (pts) with advanced pancreatic cancer $(\mathrm{PC})$ : A preliminary analysis of Cancer and Leukemia Group B (CALGB. J Clin Oncol (Meeting Abstracts). 2007; 25:4508.

295. Bruckner HW, Hrehorovich VR, Sawhney HS. Bevacizumab as treatment for chemotherapyresistant pancreatic cancer. Anticancer Res. 2005; 25:3637-3639. [PubMed: 16101193]

296. Yamasaki H, Ikeda S, Okajima M, Miura Y, Asahara T, Kohno N, Shimamoto F. Expression and localization of MUC1, MUC2, MUC5AC and small intestinal mucin antigen in pancreatic tumors. Int J Oncol. 2004; 24:107-113. [PubMed: 14654947]

297. Qu CF, Li Y, Song YJ, Rizvi SM, Raja C, Zhang D, Samra J, Smith R, Perkins AC, Apostolidis $\mathrm{C}$, Allen BJ. MUC1 expression in primary and metastatic pancreatic cancer cells for in vitro treatment by (213)Bi-C595 radioimmunoconjugate. Br J Cancer. 2004; 91:2086-2093. [PubMed: 15599383]

298. Levi E, Klimstra DS, Andea A, Basturk O, Adsay NV. MUC1 and MUC2 in pancreatic neoplasia. J Clin Pathol. 2004; 57:456-462. [PubMed: 15113850]

299. Hamanaka Y, Suehiro Y, Fukui M, Shikichi K, Imai K, Hinoda Y. Circulating anti-MUC1 IgG antibodies as a favorable prognostic factor for pancreatic cancer. Int J Cancer. 2003; 103:97-100. [PubMed: 12455059]

300. Tsutsumida H, Swanson BJ, Singh PK, Caffrey TC, Kitajima S, Goto M, Yonezawa S, Hollingsworth MA. RNA interference suppression of MUC1 reduces the growth rate and metastatic phenotype of human pancreatic cancer cells. Clin Cancer Res. 2006; 12:2976-2987. [PubMed: 16707592]

301. Basu GD, Tinder TL, Bradley JM, Gendler SJ, Petris GD, Mukherjee P. Role of MUC1 in pancreatic cancer. AACR Meeting Abstracts. 2006; 2006:1198-b.

302. Gold DV, Modrak DE, Schutsky K, Cardillo TM. Combined 90Yttrium-DOTA-labeled PAM4 antibody radioimmunotherapy and gemcitabine radiosensitization for the treatment of a human pancreatic cancer xenograft. Int J Cancer. 2004; 109:618-626. [PubMed: 14991585]

303. Hassan R, Bera T, Pastan I. Mesothelin: a new target for immunotherapy. Clin Cancer Res. 2004; 10:3937-3942. [PubMed: 15217923]

304. Argani P, Iacobuzio-Donahue C, Ryu B, Rosty C, Goggins M, Wilentz RE, Murugesan SR, Leach SD, Jaffee E, Yeo CJ, Cameron JL, Kern SE, Hruban RH. Mesothelin is overexpressed in the vast majority of ductal adenocarcinomas of the pancreas: identification of a new pancreatic cancer marker by serial analysis of gene expression (SAGE). Clin Cancer Res. 2001; 7:38623868. [PubMed: 11751476]

305. Hassan R, Laszik ZG, Lerner M, Raffeld M, Postier R, Brackett D. Mesothelin is overexpressed in pancreaticobiliary adenocarcinomas but not in normal pancreas and chronic pancreatitis. Am J Clin Pathol. 2005; 124:838-845. [PubMed: 16416732]

306. Baruch AC, Wang H, Staerkel GA, Evans DB, Hwang RF, Krishnamurthy S. Immunocytochemical study of the expression of mesothelin in fine-needle aspiration biopsy specimens of pancreatic adenocarcinoma. Diagn Cytopathol. 2007; 35:143-147. [PubMed: 17304533] 
307. Hassan R, Bullock S, Premkumar A, Kreitman RJ, Kindler H, Willingham MC, Pastan I. Phase I study of SS1P, a recombinant anti-mesothelin immunotoxin given as a bolus I.V. infusion to patients with mesothelin-expressing mesothelioma, ovarian, and pancreatic cancers. Clin Cancer Res. 2007; 13:5144-5149. [PubMed: 17785569]

308. Armstrong DK, Laheru D, Ma WW, Cohen SJ, Phillips M, Brahmer J, Weil SC, Hassan R. A phase 1 study of MORAb-009, a monoclonal antibody against mesothelin in pancreatic cancer, mesothelioma and ovarian adenocarcinoma. J Clin Oncol (Meeting Abstracts). 2007; 25:14041.

309. Nakamura M, Kubo M, Yanai K, Mikami Y, Ikebe M, Nagai S, Yamaguchi K, Tanaka M, Katano M. Anti-patched-1 antibodies suppress hedgehog signaling pathway and pancreatic cancer proliferation. Anticancer Res. 2007; 27:3743-3747. [PubMed: 17970037]

310. Loo D, Pryer N, Young P, Liang T, Coberly S, King KL, Kang K, Roberts P, Tsao M, Xu X, Potts B, Mather JP. The glycotope-specific RAV12 monoclonal antibody induces oncosis in vitro and has antitumor activity against gastrointestinal adenocarcinoma tumor xenografts in vivo. Mol Cancer Ther. 2007; 6:856-865. [PubMed: 17363480]

311. Burris HA III, Lewis N, Rosen LS, Jones SF, Cohen RB, Kunkel LA, Stewart SJ. Phase I experience with an anti-glycotope monoclonal antibody, RAV12, in recurrent adenocarcinoma. J Clin Oncol (Meeting Abstracts). 2007; 25:14017.

312. Kobari M, Egawa S, Shibuya K, Sunamura M, Saitoh K, Matsuno S. Effect of intraportal adoptive immunotherapy on liver metastases after resection of pancreatic cancer. Br J Surg. 2000; 87:43-48. [PubMed: 10606909]

313. Hahn WC. Role of telomeres and telomerase in the pathogenesis of human cancer. J Clin Oncol. 2003; 21:2034-2043. [PubMed: 12743159]

314. Hiyama E, Kodama T, Shinbara K, Iwao T, Itoh M, Hiyama K, Shay JW, Matsuura Y, Yokoyama $\mathrm{T}$. Telomerase activity is detected in pancreatic cancer but not in benign tumors. Cancer Res. 1997; 57:326-331. [PubMed: 9000577]

315. Myung SJ, Kim MH, Kim YS, Kim HJ, Park ET, Yoo KS, Lim BC, Wan Seo D, Lee SK, Min YI, Kim JY. Telomerase activity in pure pancreatic juice for the diagnosis of pancreatic cancer may be complementary to K-ras mutation. Gastrointest Endosc. 2000; 51:708-713. [PubMed: 10840305]

316. Sato N, Maehara N, Mizumoto K, Nagai E, Yasoshima T, Hirata K, Tanaka M. Telomerase activity of cultured human pancreatic carcinoma cell lines correlates with their potential for migration and invasion. Cancer. 2001; 91:496-504. [PubMed: 11169932]

317. Tang SJ, Dumot JA, Wang L, Memmesheimer C, Conwell DL, Zuccaro G, Goormastic M, Ormsby AH, Cowell J. Telomerase activity in pancreatic endocrine tumors. Am J Gastroenterol. 2002; 97:1022-1030. [PubMed: 12003383]

318. Sato N, Mizumoto K, Kusumoto M, Nishio S, Maehara N, Urashima T, Ogawa T, Tanaka M. Upregulation of telomerase activity in human pancreatic cancer cells after exposure to etoposide. $\mathrm{Br}$ J Cancer. 2000; 82:1819-1826. [PubMed: 10839297]

319. Kusumoto M, Ogawa T, Mizumoto K, Ueno H, Niiyama H, Sato N, Nakamura M, Tanaka M. Adenovirus-mediated p53 gene transduction inhibits telomerase activity independent of its effects on cell cycle arrest and apoptosis in human pancreatic cancer cells. Clin Cancer Res. 1999; 5:2140-2147. [PubMed: 10473098]

320. Teng LS, Fahey TJ 3rd. Can inhibition of telomerase increase pancreatic cancer cell's susceptibility to chemotherapeutic reagents? Hepatobiliary Pancreat Dis Int. 2002; 1:155-160. [PubMed: 14607648]

321. Wang YF, Guo KJ, Huang BT, Liu Y, Tang XY, Zhang JJ, Xia Q. Inhibitory effects of antisense phosphorothioate oligodeoxynucleotides on pancreatic cancer cell Bxpc-3 telomerase activity and cell growth in vitro. World J Gastroenterol. 2006; 12:4004-4008. [PubMed: 16810748]

322. Schmidt J, Ryschich E, Sievers E, Schmidt-Wolf IG, Buchler MW, Marten A. Telomerasespecific T-cells kill pancreatic tumor cells in vitro and in vivo. Cancer. 2006; 106:759-764. [PubMed: 16369992]

323. Mukherjee P, Ginardi AR, Madsen CS, Sterner CJ, Adriance MC, Tevethia MJ, Gendler SJ. Mice with spontaneous pancreatic cancer naturally develop MUC-1-specific CTLs that eradicate tumors when adoptively transferred. J Immunol. 2000; 165:3451-3460. [PubMed: 10975866] 
324. Kawakami Y, Okada T, Akada M. Development of immunotherapy for pancreatic cancer. Pancreas. 2004; 28:320-325. [PubMed: 15084980]

325. Yamaguchi Y, Ohta K, Kawabuchi Y, Ohshita A, Okita R, Okawaki M, Hironaka K, Matsuura K, Toge T. Feasibility study of adoptive immunotherapy for metastatic lung tumors using peptidepulsed dendritic cell-activated killer (PDAK) cells. Anticancer Res. 2005; 25:2407-2415. [PubMed: 16080467]

326. Balkwill FR, Lee A, Aldam G, Moodie E, Thomas JA, Tavernier J, Fiers W. Human tumor xenografts treated with recombinant human tumor necrosis factor alone or in combination with interferons. Cancer Res. 1986; 46:3990-3993. [PubMed: 2425938]

327. Sato T, Yamauchi N, Sasaki H, Takahashi M, Okamoto T, Sakamaki S, Watanabe N, Niitsu Y. An apoptosis-inducing gene therapy for pancreatic cancer with a combination of 55-kDa tumor necrosis factor (TNF) receptor gene transfection and mutein TNF administration. Cancer Res. 1998; 58:1677-1683. [PubMed: 9563482]

328. Schmiegel WH, Caesar J, Kalthoff H, Greten H, Schreiber HW, Thiele HG. Antiproliferative effects exerted by recombinant human tumor necrosis factor-alpha (TNF-alpha) and interferongamma (IFN-gamma) on human pancreatic tumor cell lines. Pancreas. 1988; 3:180-188. [PubMed: 3131759]

329. Rasmussen H, Rasmussen C, Lempicki M, Durham R, Brough D, King CR, Weichselbaum R. TNFerade Biologic: preclinical toxicology of a novel adenovector with a radiation-inducible promoter, carrying the human tumor necrosis factor alpha gene. Cancer Gene Ther. 2002; 9:951957. [PubMed: 12386834]

330. Staba MJ, Mauceri HJ, Kufe DW, Hallahan DE, Weichselbaum RR. Adenoviral TNF-alpha gene therapy and radiation damage tumor vasculature in a human malignant glioma xenograft. Gene Ther. 1998; 5:293-300. [PubMed: 9614548]

331. Chung TD, Mauceri HJ, Hallahan DE, Yu JJ, Chung S, Grdina WL, Yajnik S, Kufe DW, Weichselbaum RR. Tumor necrosis factor-alpha-based gene therapy enhances radiation cytotoxicity in human prostate cancer. Cancer Gene Ther. 1998; 5:344-349. [PubMed: 9917088]

332. Gupta VK, Park JO, Jaskowiak NT, Mauceri HJ, Seetharam S, Weichselbaum RR, Posner MC. Combined gene therapy and ionizing radiation is a novel approach to treat human esophageal adenocarcinoma. Ann Surg Oncol. 2002; 9:500-504. [PubMed: 12052763]

333. Hallahan DE, Mauceri HJ, Seung LP, Dunphy EJ, Wayne JD, Hanna NN, Toledano A, Hellman S, Kufe DW, Weichselbaum RR. Spatial and temporal control of gene therapy using ionizing radiation. Nat Med. 1995; 1:786-791. [PubMed: 7585181]

334. Posner M, Chang KJ, Rosemurgy A, Stephenson J, Khan M, Reid T, Fisher WE, Waxman I, Von Hoff D, Hecht R Jr. Multi-center phase II/III randomized controlled clinical trial using TNFerade combined with chemoradiation in patients with locally advanced pancreatic cancer (LAPC). J Clin Oncol (Meeting Abstracts). 2007; 25:4518.

335. Du C, Feng N, Jin H, Lee V, Wang M, Wright JA, Young AH. Macrophages play a critical role in the anti-tumor activity of Virulizin. Int J Oncol. 2003; 23:1341-1346. [PubMed: 14532975]

336. Li H, Cao MY, Lee Y, Lee V, Feng N, Benatar T, Jin H, Wang M, Der S, Wright JA, Young AH. Virulizin, a novel immunotherapy agent, activates NK cells through induction of IL-12 expression in macrophages. Cancer Immunol Immunother. 2005; 54:1115-1126. [PubMed: 15891881]

337. Li H, Cao MY, Lee Y, Benatar T, Lee V, Feng N, Gu X, Liu P, Jin H, Wang M, Der S, Lightfoot J, Wright JA, Young AH. Virulizin, a novel immunotherapy agent, stimulates TNFalpha expression in monocytes/macrophages in vitro and in vivo. Int Immunopharmacol. 2007; 7:1350-1359. [PubMed: 17673150]

338. Benatar T, Cao MY, Lee Y, Feng N, Gu X, Lee V, Jin H, Wang M, Der S, Wright JA, Young AH. Virulizin induces production of IL-17E to enhance antitumor activity by recruitment of eosinophils into tumors. J Clin Oncol (Meeting Abstracts). 2005; 23:2537.

339. Liu C, Ferdinandi ES, Ely G, Joshi SS. Virulizin-2gamma, a novel immunotherapeutic agent, in treatment of human pancreatic cancer xenografts. Int J Oncol. 2000; 16:1015-1020. [PubMed: 10762639] 
340. Feng N, Jin H, Wang M, Du C, Wright JA, Young AH. Antitumor activity of Virulizin, a novel biological response modifier (BRM) in a panel of human pancreatic cancer and melanoma xenografts. Cancer Chemother Pharmacol. 2003; 51:247-255. [PubMed: 12655444]

341. Wright JA, Osterlee J, Fekete S, Lee Y, Young AH. A phase III trial of virulizin plus gemcitabine vs. gemcitabine alone in advanced pancreatic cancer: Results of subgroup analysis. J Clin Oncol (Meeting Abstracts). 2006; 24:4116.

342. Jaffee EM, Hruban RH, Biedrzycki B, Laheru D, Schepers K, Sauter PR, Goemann M, Coleman J, Grochow L, Donehower RC, Lillemoe KD, O'Reilly S, Abrams RA, Pardoll DM, Cameron JL, Yeo CJ. Novel allogeneic granulocyte-macrophage colony-stimulating factor-secreting tumor vaccine for pancreatic cancer: a phase I trial of safety and immune activation. J Clin Oncol. 2001; 19:145-156. [PubMed: 11134207]

343. Kimura M, Tagawa M, Yoshida Y, Takenouchi T, Takenaga K, Azuma K, Yamaguchi T, Saisho $\mathrm{H}$, Sakiyama S. Impaired in vivo tumor growth of human pancreatic carcinoma cells retrovirally transduced with GM-CSF gene. Anticancer Res. 1998; 18:165-170. [PubMed: 9568072]

344. Laheru D, Yeo C, Biedrzycki B, Solt S, Lutz E, Onners B, Tartakovsky I, Herman J, Hruban R, Piantadosi S, Jaffee E. A safety and efficacy trial of lethally irradiated allogeneic pancreatic tumor cells transfected with the GM-CSF gene in combination with adjuvant chemoradiotherapy for the treatment of adenocarcinoma of the pancreas. J Clin Oncol (Meeting Abstracts). 2007; 25:3010.

345. Toubaji A, Achtar MS, Herrin VE, Provenzano M, Bernstein S, Brent-Steel T, Marincola F, Khleif SN. Immunotherapeutic role of mutant ras peptide-based vaccine as an adjuvant in pancreatic and colorectal cancer. J Clin Oncol (Meeting Abstracts). 2005; 23:2573.

346. Gjertsen MK, Bakka A, Breivik J, Saeterdal I, Gedde-Dahl T 3rd, Stokke KT, Solheim BG, Egge TS, Soreide O, Thorsby E, Gaudernack G. Ex vivo ras peptide vaccination in patients with advanced pancreatic cancer: results of a phase I/II study. Int J Cancer. 1996; 65:450-453. [PubMed: 8621226]

347. Gjertsen MK, Buanes T, Rosseland AR, Bakka A, Gladhaug I, Soreide O, Eriksen JA, Moller M, Baksaas I, Lothe RA, Saeterdal I, Gaudernack G. Intradermal ras peptide vaccination with granulocyte-macrophage colony-stimulating factor as adjuvant: Clinical and immunological responses in patients with pancreatic adenocarcinoma. Int J Cancer. 2001; 92:441-450. [PubMed: 11291084]

348. Achtar MS, Toubaji A, Herrin V, Gause B, Hamilton M, Berhens R, Grollman F, Bernstein S, Khleif S. Phase II clinical trial of mutant Ras peptide vaccine in combination with GM-CSF and IL-2 in advanced cancer patients. J Clin Oncol Meeting Abstracts). 2007; 25:3067.

349. Buanes T, Bernhardt S, Lislerud K, Gladhaug I, Moeller M, Eriksen JA, Gaudernack G. RAS peptide vaccination in resected pancreatic cancer patients - persistence of anti tumour response and long term survival. J Clin Oncol (Meeting Abstracts). 2007; 25:4543.

350. Lieberman SM, Horig H, Kaufman HL. Innovative treatments for pancreatic cancer. Surg Clin North Am. 2001; 81:715-739. [PubMed: 11459285]

351. Duraker N, Hot S, Polat Y, Hobek A, Gencler N, Urhan N. CEA, CA 19-9, and CA 125 in the differential diagnosis of benign and malignant pancreatic diseases with or without jaundice. $\mathrm{J}$ Surg Oncol. 2007; 95:142-147. [PubMed: 17262731]

352. Ozkan H, Kaya M, Cengiz A. Comparison of tumor marker CA 242 with CA 19-9 and carcinoembryonic antigen (CEA) in pancreatic cancer. Hepatogastroenterology. 2003; 50:16691674. [PubMed: 14571813]

353. Banfi G, Bravi S, Ardemagni A, Zerbi A. CA 19.9, CA 242 and CEA in the diagnosis and followup of pancreatic cancer. Int J Biol Markers. 1996; 11:77-81. [PubMed: 8776607]

354. Garnett CT, Greiner JW, Tsang KY, Kudo-Saito C, Grosenbach DW, Chakraborty M, Gulley JL, Arlen PM, Schlom J, Hodge JW. TRICOM vector based cancer vaccines. Curr Pharm Des. 2006; 12:351-361. [PubMed: 16454749]

355. Marshall JL, Gulley JL, Arlen PM, Beetham PK, Tsang KY, Slack R, Hodge JW, Doren S, Grosenbach DW, Hwang J, Fox E, Odogwu L, Park S, Panicali D, Schlom J. Phase I study of sequential vaccinations with fowlpox-CEA(6D)-TRICOM alone and sequentially with vacciniaCEA(6D)-TRICOM, with and without granulocyte-macrophage colony-stimulating factor, in 
patients with carcinoembryonic antigen-expressing carcinomas. J Clin Oncol. 2005; 23:720-731. [PubMed: 15613691]

356. Marshall JL, Hawkins MJ, Tsang KY, Richmond E, Pedicano JE, Zhu M, Schlom J. Phase I Study in Cancer Patients of a Replication-Defective Avipox Recombinant Vaccine That Expresses Human Carcinoembryonic Antigen. J Clin Oncol. 1999; 17:332. [PubMed: 10458251]

357. Ramanathan RK, Lee KM, McKolanis J, Hitbold E, Schraut W, Moser AJ, Warnick E, Whiteside T, Osborne J, Kim H, Day R, Troetschel M, Finn OJ. Phase I study of a MUC1 vaccine composed of different doses of MUC1 peptide with SB-AS2 adjuvant in resected and locally advanced pancreatic cancer. Cancer Immunol Immunother. 2005; 54:254-264. [PubMed: 15372205]

358. Nordqvist, C., editor. Therion reports results of phase 3 PANVAC-VF trial and announces plans for company sale. Medical News Today. 2006.

359. Brett BT, Smith SC, Bouvier CV, Michaeli D, Hochhauser D, Davidson BR, Kurzawinski TR, Watkinson AF, Van Someren N, Pounder RE, Caplin ME. Phase II study of anti-gastrin-17 antibodies, raised to G17DT, in advanced pancreatic cancer. J Clin Oncol. 2002; 20:4225-4231. [PubMed: 12377966]

360. Gilliam AD, Topuzov EG, Garin AM, Pulay I, Broome P, Watson SA, Rowlands B, Takhar A, Beckingham I. Randomised, double blind, placebo-controlled, multi-centre, group-sequential trial of G17DT for patients with advanced pancreatic cancer unsuitable or unwilling to take chemotherapy. J Clin Oncol (Meeting Abstracts). 2004; 22:2511.

361. Shapiro J, Marshall J, Karasek P, Figer A, Oettle H, Couture F, Jeziorski K, Broome P, Hawkins R. G17DT+gemcitabine [Gem] versus placebo+Gem in untreated subjects with locally advanced, recurrent, or metastatic adenocarcinoma of the pancreas: Results of a randomized, double-blind, multinational, multicenter study. J Clin Oncol (Meeting Abstracts). 2005; 23:LBA4012.

362. Thomas AM, Santarsiero LM, Lutz ER, Armstrong TD, Chen YC, Huang LQ, Laheru DA, Goggins M, Hruban RH, Jaffee EM. Mesothelin-specific CD8(+) T cell responses provide evidence of in vivo cross-priming by antigen-presenting cells in vaccinated pancreatic cancer patients. J Exp Med. 2004; 200:297-306. [PubMed: 15289501]

363. Gaffney MC, Goedegebuure P, Kashiwagi H, Hornick JR, Thaker RI, Eberlein T, Hawkins WG. DNA vaccination targeting mesothelin combined with anti-GITR antibody induces rejection of pancreatic adenocarcinoma. AACR Meeting Abstracts. 2006; 2006:329-a.

364. Cohen AD, Diab A, Perales MA, Wolchok JD, Rizzuto G, Merghoub T, Huggins D, Liu C, Turk MJ, Restifo NP, Sakaguchi S, Houghton AN. Agonist anti-GITR antibody enhances vaccineinduced CD8(+) T-cell responses and tumor immunity. Cancer Res. 2006; 66:4904-4912. [PubMed: 16651447]

365. Esparza EM, Arch RH. Glucocorticoid-induced TNF receptor functions as a costimulatory receptor that promotes survival in early phases of T cell activation. J Immunol. 2005; 174:78697874. [PubMed: 15944292]

366. Bernhardt SL, Gjertsen MK, Trachsel S, Moller M, Eriksen JA, Meo M, Buanes T, Gaudernack G. Telomerase peptide vaccination of patients with non-resectable pancreatic cancer: A dose escalating phase I/II study. Br J Cancer. 2006; 95:1474-1482. [PubMed: 17060934]

367. Bernhardt SL, Buanes TA, Moller M, Eriksen JA, Geudernack G. Imiquimod a new adjuvant for telomerase peptide vaccine: A phase I trial in patients with inoperable pancreatic cancer. J Clin Oncol (Meeting Abstracts). 2005; 23:9623.

368. Chang DZ, Zhu K, Kopetz S, Voo K, Li Y, Hwu P, Radvanyi L, Abbruzzese JL. Presence of survivin-specific cytotoxic T-lymphocytes (CTLs) in pancreatic cancer patients, and specific killing of human pancreatic carcinoma cells in vitro by survivin-specific CTLs. J Clin Oncol (Meeting Abstracts). 2007; 25:3070.

369. Zhu K, Qin H, Cha SC, Neelapu SS, Overwijk W, Lizee GA, Abbruzzese JL, Hwu P, Radvanyi L, Kwak LW, Chang DZ. Survivin DNA vaccine generated specific antitumor effects in pancreatic carcinoma and lymphoma mouse models. Vaccine. 2007; 25:7955-7961. [PubMed: 17933439]

370. Wobser M, Keikavoussi P, Kunzmann V, Weininger M, Andersen MH, Becker JC. Complete remission of liver metastasis of pancreatic cancer under vaccination with a HLA-A2 restricted 
peptide derived from the universal tumor antigen survivin. Cancer Immunol Immunother. 2006; 55:1294-1298. [PubMed: 16315030]

371. Miyazaki J, Tsuzuki Y, Matsuzaki K, Hokari R, Okada Y, Kawaguchi A, Nagao S, Itoh K, Miura S. Combination therapy with tumor-lysate pulsed dendritic cells and antiangiogenic drug TNP-470 for mouse pancreatic cancer. Int J Cancer. 2005; 117:499-505. [PubMed: 15906361]

372. Morse MA, Nair SK, Boczkowski D, Tyler D, Hurwitz HI, Proia A, Clay TM, Schlom J, Gilboa E, Lyerly HK. The feasibility and safety of immunotherapy with dendritic cells loaded with CEA mRNA following neoadjuvant chemoradiotherapy and resection of pancreatic cancer. Int $\mathbf{J}$ Gastrointest Cancer. 2002; 32:1-6. [PubMed: 12630764]

373. Pecher G, Haring A, Kaiser L, Thiel E. Mucin gene (MUC1) transfected dendritic cells as vaccine: results of a phase I/II clinical trial. Cancer Immunol Immunother. 2002; 51:669-673. [PubMed: 12439613]

374. Finn OJ, Whiteside T, McKolanis J, Moser AJ, Zeh H, Lee K, Bartlett D, Schmotzer A, Ramanathan RK. A phase 1B study of a MUC1 pulsed autologous dendritic cell (DC) vaccine as adjuvant therapy in patients (Pts) with resected pancreatic or biliary tumors. J Clin Oncol (Meeting Abstracts). 2004; 22:2578. 
Table 1

Biological approaches to therapy of pancreatic cancer

Gene therapy and signal transduction inhibition

- Antisense oligonucleotides

- RNA interference

- Dominant negative mutants

- Small molecule inhibitors

- Gene restoration

- $\quad$ Suicide gene therapy

Antiangiogenic and matrix metalloproteinase inhibitors

Oncolytic viral therapy

Immunotherapy

- Antibodies - inhibitory, immunotoxin, radioconjugate

- $\quad$ Adoptive cell transfer

- Cytokines and immunomodulators

- Vaccines - DNA, peptide, whole cell, antigen-pulsed dendritic cells 
Table 2

Genetic and molecular aberrations in pancreatic cancer

\begin{tabular}{ll}
\hline & Frequency $(\%)$ \\
\hline K-ras & $75-90$ \\
EGFR & 69 \\
Akt2 & 20 \\
Bcl-2 & 23 \\
Bcl-xL & 90 \\
COX-2 & $44-90$ \\
Gastrin precursors \& gastrin & $23-91$ \\
CCK-B receptor & 95 \\
IGF-1R & 64 \\
FAK & $48-75$ \\
Smad4 & 55 \\
T $\beta$ RI & 1 \\
T $\beta$ RII & 4 \\
Shh & 70 \\
Notch3 & $69-74$ \\
CaSm (LSM1) & 87 \\
p16 ${ }^{\text {NNK4A }}$ (MTS1) & 85 \\
BIRC5 (survivin) & $77-94$ \\
pRb & 6 \\
p53 & $50-75$ \\
VEGF & 93 \\
c-Met-encoded HGF receptor & $61-87$ \\
MUC1 & 90 \\
Mesothelin & $90-100$ \\
RAAG12 & 100 \\
Telomerase & $92-95$ \\
CEA & $85-90$ \\
\hline &
\end{tabular}

Pancreatology. Author manuscript; available in PMC 2010 June 08. 
Table 3

Selected pancreatic cancer clinical trials in progress (Source: National Cancer Institute)

\begin{tabular}{|c|c|c|}
\hline Phase & Treatment & Disease stage \\
\hline \multirow[t]{2}{*}{ III } & $\left.\begin{array}{l}\text { Eriotinib, gemcitabine and capecitabine } \\
\text { Curcumin, celecoxib and gemcitabine } \\
\text { Axitinib and gemcitabine } \\
\text { Sorafenib and gemcitabine } \\
\text { GV1001 and gemcitabine }\end{array}\right\}$ & $\begin{array}{c}\text { Locally } \\
\text { advanced/metastatic }\end{array}$ \\
\hline & TNFerade, 5-FU and radiotherapy & Locally advanced \\
\hline \multirow[t]{3}{*}{ II } & $\begin{array}{l}\text { Curcumin and gemcitabine } \\
\text { Cetuximab and bevacizumab } \\
\text { ARQ } 197 \text { and gemcitabine } \\
\text { ARRY-142886 (AZD6244) and } \\
\text { capecitabine }\end{array}$ & $\begin{array}{c}\text { Locally } \\
\text { advanced/metastatic } \\
\text { (Second line) }\end{array}$ \\
\hline & $\left.\begin{array}{l}\text { Lapatinib (GW572016) and gemcitabine } \\
\text { Everolimus (RAD001) }\end{array}\right\}$ & Metastatic \\
\hline & Sirolimus (rapamycin) & Advanced \\
\hline \multirow[t]{5}{*}{$\mathrm{I} / \mathrm{II}$} & $\begin{array}{l}\text { Erlotinib, bevacizumab, gemcitabine and } \\
\text { capecitabine }\end{array}$ & $\begin{array}{l}\text { Locally } \\
\text { advanced/metastatic }\end{array}$ \\
\hline & PTK 787 (ZK222584) and gemcitabine & Advanced \\
\hline & Survivin peptide & $\begin{array}{l}\text { Advanced (also melanoma, } \\
\text { colon and cervical cancers) }\end{array}$ \\
\hline & Bevacizumab and gemcitabine & $\begin{array}{l}\text { Completely removed } \\
\text { surgically }\end{array}$ \\
\hline & $\begin{array}{l}\text { Bevacizumab, 5-FU, oxaliplatin, } \\
\text { gemcitabine and radiotherapy }\end{array}$ & Locally advanced \\
\hline
\end{tabular}

